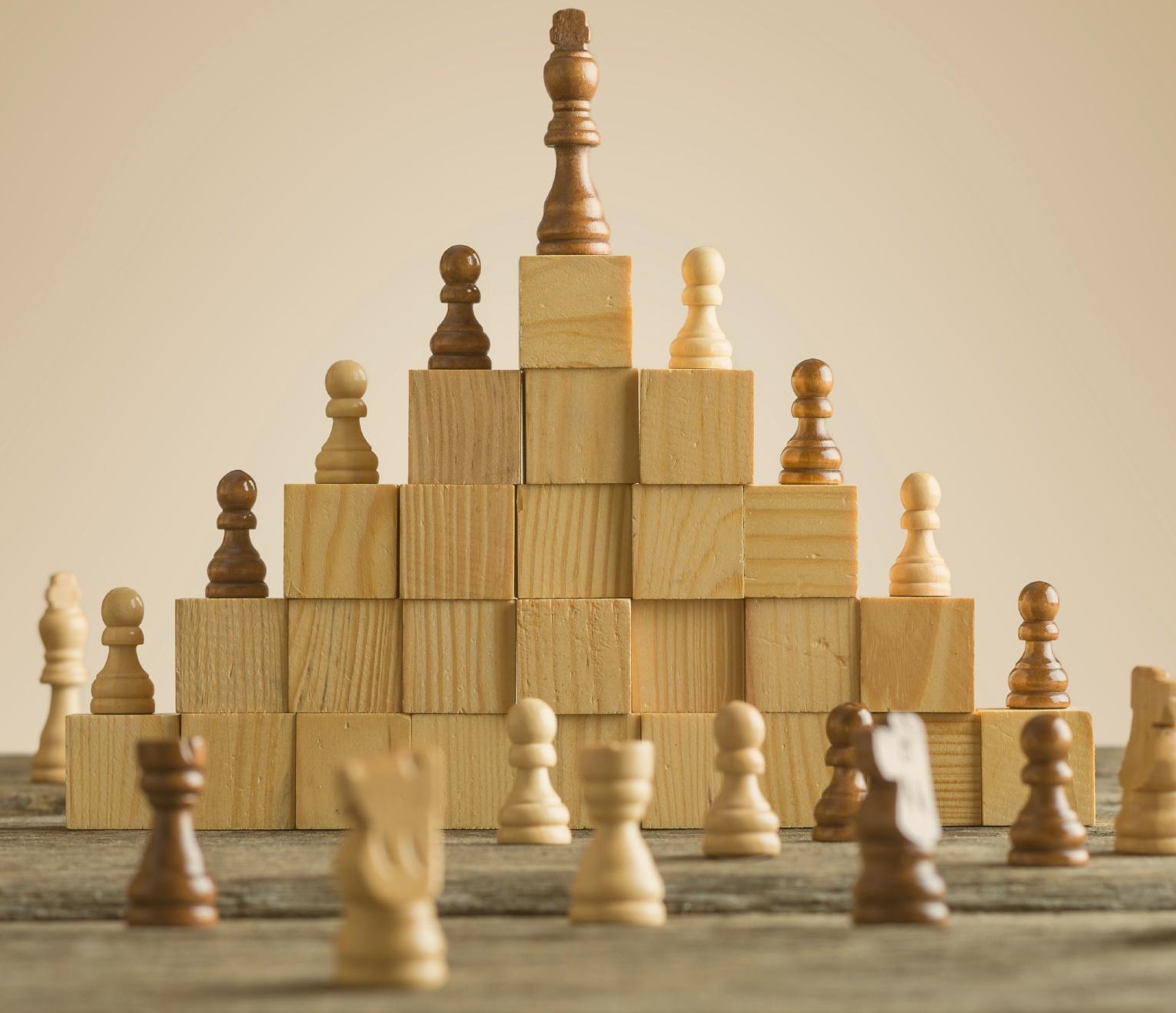

\title{
ELITA VS. L'UDIA: Čo vieme o populizme
}

Ivana Piterová

Bibiána Kováčová Holevová

Alexander Loziak 


\section{ELITA VS. I'UDIA: Čo vieme o populizme}

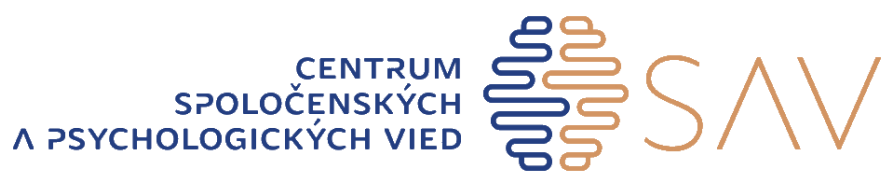

Košice 2021 


\section{Elita vs. L'udia: Čo vieme o populizme}

Vedecká monografia

(C) 2021 Autori publikácie

Spoločenskovedný ústav Centra spoločenských a psychologických vied SAV

\section{Vydavatel':}

Spoločenskovedný ústav CSPV SAV

Karpatská 5

04001 Košice

Slovenská republika

\section{Autori:}

Ivana Piterová

Bibiána Kováčová Holevová

Alexander Loziak

\section{Recenzenti:}

prof. PhDr. Jozef Výrost, DrSc.

prof. PhDr. Jozef Džuka, CSc.

Publikácia je súčastou riešenia výskumného projektu VEGA MŠVVaŠ SR a SAV č. 2/0065/21 "Sociálne a psychologické koreláty populistických postojov".

(ङ) (1) Publikácia je šírená pod licenciou Creative Commons Attribution 4.0 International. Dielo je možné opakovane používat'za predpokladu uvedenia mien autorov.

Publikácia neprešla jazykovou korektúrou.

ISBN 978-80-89524-57-0

https://doi.org/10.31577/2021.9788089524570 


\section{OBSAH}

\section{PREDSLOV \\ O AUTOROCH}

1. KAPITOLA

POPULIZMUS, PRÍČINY A DÔSLEDKY .............................................

2. KAPITOLA

POPULISTICKÉ POSTOJE............................................................20

3. KAPITOLA

POPULISTICKÉ POSTOJE VS. KONŠPIRAČNÉ MYSLENIE ..........................31

4. KAPITOLA

VÝVOJ MERACÍCH NÁSTROJOV POPULISTICKÝCH POSTOJOV.

ZOZNAM POUŽITEJ LITERATÚRY....................................70

PRÍLOHY....................................................................88 


\section{PREDSLOV}

Populizmus je síce vo svete i na Slovensku prítomný už desatročia, avšak v posledných rokoch rapídne vzrástol záujem o túto tému, čo súvisí so sociálnym a politickým dianím doma i vo svete. O jej aktuálnosti svedčí množstvo literatúry z rôznych vedných odborov a taktiež frekvencia a rozsah, $v$ akom sa termín populizmus objavuje $v$ médiách, $v$ odbornom $\mathrm{i}$ laickom diskurze. Napriek tomu, že sa o populizme často rozpráva, mnoho l'udí nevie, čo presne znamená a aký môže mat' význam pre dnešnú spoločnost'.

Otázkou, ktorú si odborná verejnost' dlhé roky kladie, je, či je populizmus prostriedkom pre zmenu alebo hrozbou pre liberálnu demokraciu. Populizmus zohráva svoju rolu napríklad pri politickej mobilizácii tak, že vyzýva l'udí a dáva hlas l'ud'om, ktorí sa cítia byt' nevypočutí. Na druhej strane, populizmus zdôrazňovaním rozdielov medzi l'ud'mi a elitou prehlbuje polarizáciu spoločnosti, ktorá môže viest' za určitých podmienok v nestálych demokraciách, k zvýšenej podpore autoritárskeho režimu. Taktiež môže obmedzit' práva menšín. Aby sme vedeli predchádzat́ prípadným negatívnym dôsledkom populizmu na rôzne aspekty života obyvatel'ov a celospoločenského diania v krajine, je dôležité sa zamerat́ nielen na politických lídrov, ale tiež na l'udí, ktorí na takýto obsah reagujú, či už zdiel'aním rovnakého postoja alebo svojim správaním.

Ciel'om tejto knihy je zhrnút existujúce poznatky $\mathrm{k}$ téme populizmu a populistických postojov. Laickej verejnosti môže táto kniha pomôct' zorientovat' sa v problematike. Možno ju chápat' ako úvod do tejto témy. Človeku z akademickej pôdy poskytuje okrem súhrnu aktuálnych poznatkov viacerých vedných disciplín aj analýzu rôznych spôsobov merania tohto konštruktu v sociálnych vedách. Publikácia poskytuje dostatočne široké teoretické základy na to, aby sa na týchto informáciách mohlo stavat pri plánovaní d’alších krokov výskumu projektu, v rámci ktorého je táto publikácia vydaná.

Prvá kapitola sa venuje definovaniu populizmu, jeho potenciálnym príčinám a dôsledkom. V druhej kapitole sú rozoberané populistické postoje l'udí a psychologické procesy, ktoré prebiehajú v pozadí, vrátane individuálnych predispozícii a národného kontextu. $\mathrm{V}$ tretej kapitole je ciel'om objasnenie rozdielov a podobností medzi populistickými postojmi a konšpiračným myslením. V štvrtej kapitole je popísaný vývoj meracích 
nástrojov populistických postojov a porovnanie existujúcich metodík ako východisko pre d’alší výskum. Originálne (anglické) verzie metodík, ktoré sú súčastou štvrtej kapitoly, sú uvedené v prílohách.

Autorský kolektív tejto publikácie tvoria výskumná pracovníčka a výskumný pracovník zo Spoločenskovedného ústavu Centra spoločenských a psychologických vied SAV a odborná asistentka Katedry psychológie, Filozofickej fakulty Univerzity Pavla Jozefa Šafárika v Košiciach. Vzhladom na výskumné zameranie autorov je téma populizmu a populistických postojov riešená z pohl'adu sociálnej psychológie, pričom autori čerpajú z odbornej literatúry viacerých vedných disciplín, spoločenských, najmä politických vied.

Táto monografia vyšla s finančnou podporou projektu č. 2/0065/21: Sociálne a psychologické koreláty populistických postojov vedeckej grantovej agentúry VEGA MŠVVaŠ a SAV. Za konštruktívne recenzné posudky $\mathrm{k}$ jednotlivým kapitolám chceme pod'akovat' prof. PhDr. Jozefovi Výrostovi, DrSc. a prof. PhDr. Jozefovi Džukovi, CSc.

Ivana Piterová

Bibiána Kováčová Holevová

Alexander Loziak 


\section{O AUTOROCH}

Ivana Piterová je vedeckou pracovníčkou Spoločenskovedného ústavu CSPV SAV. V rámci svojho výskumného zamerania sa venuje sociálnopsychologickej problematike postojov, najmä populistickým postojom a postojom $k$ migrácii. Je hlavnou riešitel'kou projektu VEGA 2/0065/21: Sociálne a psychologické koreláty populistických postojov a spoluriešitel'kou projektu VEGA 2/0068/19: Postoje k migrantom v sociálno-psychologických kontextoch. Okrem toho, že sa aktívne podiel'a na medzinárodnom projekte European Social Survey - Európska sociálna sonda, zabezpečovala účast' Slovenska v medzinárodnom a medzikultúrnom projekte Towards Gender Harmony, ktorého výstupy možno nájst' v časopisoch European Journal of Social Psychology alebo Cross-Cultural Psychology.

Bibiána Kováčová Holevová je odbornou asistentkou Katedry psychológie FF UPJŠ v Košiciach. Je, resp. bola spoluriešitel'kou viacerých VEGA a APVV projektov týkajúcich sa (procesov) dosahovania ciel'ov, aktuálne i projektu VEGA 2/0065/21: Sociálne a psychologické koreláty populistických postojov. Ako vysokoškolský pedagóg vyučuje psychológiu emócií a motivácie, sociálnu psychológiu, ako i aplikovanú sociálnu psychológiu, ktorej súčastóu je i politická psychológia, do sféry ktorých spadá i problematika populistických postojov. Medzi d’alšie oblasti jej výskumného zamerania patria vplyv médií, sebakontrola či starostlivost́ o seba.

Alexander Loziak je vedeckým pracovníkom Spoločenskovedného ústavu CSPV SAV. Medzi oblasti jeho výskumného zamerania patria: pracovný stres a možnosti jeho redukcie, problémy $v$ školstve a konšpiračné myslenie. Je spoluriešitel'om projektov VEGA 2/0065/21: Sociálne a psychologické koreláty populistických postojov a VEGA 2/0012/19: Reflexia slovenského národnostného školstva v Mad'arsku v kontexte súčasnosti a d'alších perspektiv jeho fungovania. 


\section{KAPITOLA}

\section{POPULIZMUS, PRÍČINY A DÔSLEDKY}

\section{Čo je to populizmus?}

Napriek tomu, že nejde o nový termín, v ostatnom období rapídne narástol záujem rôznych spoločenských vied o koncept populizmu, jeho definovanie a meranie. Diverzita v súvislosti s definovaním populizmu i metodologická heterogenita súvisí s množstvom prístupov, napr. ideologický, sociálnokultúrny, politicko-strategický. Populizmus je vodbornej literatúre definovaný rôzne, ako ideológia (Mudde, 2004), súbor postojov l'udí (Hawkins a kol., 2019), politické hnutie (Jansen, 2011), politická stratégia (Weyland, 2017), špecifický politický štýl (Moffitt \& Torney, 2014; Urbinati, 2013) alebo komunikačný štýl (Jagers \& Walgrave, 2007; de Vreese a kol., 2018) či diskurzný rámec (Aslanidis, 2016). Vo verejnom diskurze a v médiách sa tento pojem zväčša používa ako označenie pre zdiskreditovanie politického súpera, často $v$ spojení stermínmi ako demagógia (manipulácia lúdí za účelom získania vplyvu a moci) či oportunizmus (prispôsobovanie sa okolnostiam podla očakávaných výhod). Zjednodušené chápanie populizmu len ako jednoduchej a na emócie zameranej rétoriky, presadzovania nevýhodných ekonomických programov a ponúkania jednoduchých riešení na zložité problémy (Muro, 2017) prispieva knegatívnej konotácii, ktorú tento pojem nadobudol u laickej verejnosti a mediálnom diskurze, čo sa občas premieta aj do odbornej diskusie.

Napriek nejasnostiam, ktoré vyplývajú z multidisciplinárnej podstaty populizmu a zovšeobecňovania výsledkov regionálnych výskumov, možno pomocou identifikácie klúčových charakteristík porozumiet' tomuto komplexnému pojmu. $V$ spoločenských vedách, najmä politických a sociologických, dominujú tri bazálne pohlady na populizmus, ktoré sa navzájom do istej miery prelínajú. Tie definujú populizmus ako ideológiu, komunikačný štýl alebo ako politickú stratégiu (Gidron \& Bonikowski, 2013).

\section{Populizmus ako ideológia}

Jednu z často citovaných definícií populizmu ako ideológie predstavil vo svojich knihách a článkoch uznávaný holandský politológ Cas Mudde, ktorý 
sa výskumne orientuje najmä na pravicový populizmus (pozri napr. Mudde, 2019). Populizmus definuje ako

ideológiu s obmedzeným definičným základom, podla ktorej je spoločnost' rozdelená do dvoch homogénnych a antagonických skupín, „morálne čistí l'udia“ verzus „skorumpovaná elita“, a ktorá zdôrazňuje, že politika by mala byt' vyjadrením všeobecnej vôle l'udu (Mudde, 2004, s. 543).

Podla tejto definície populizmus súvisí s manichejským, bipolárnym vnímaním usporiadania spoločnosti, teda spoločnost', v ktorej existujú len priatelia a nepriatelia (Mudde, 2004). Spoločnost' je rozdelená len na dve rovnorodé a protichodné skupiny: l'ud a elitu, pričom rozdiel medzi nimi je podl'a autora najmä morálny. Bežní l'udia (common people) sú popisovaní ako táǎko pracujúci, platiaci dane, dodržiavajúci zákony, s vysokým morálnym základom, takže je l'ahké sa s touto skupinou identifikovat'. Spoločným nepriatel'om bežných l'udí je elita, ktorá je popisovaná ako skorumpovaná, arogantná, zameraná na seba. Najčastejšie sa spája s politickou elitou, no môže íst' aj o podnikatel'ov, bankárov, manažérov medzinárodných spoločností či dokonca vedcov alebo inštitúcie ako sú EÚ, NATO, Svetová banka a podobne (Aslanidis, 2011, s. 5-6). Vychádzajúc z definície taktiež vieme, že politika má byt' zameraná na l'udí a má vychádzat' z ich vôle, napÍnat' ich potreby.

Kedže je populizmus ideológiou s obmedzeným definičným základom, neodpovedá na všetky hlavné spoločensko-politické otázky, no môže sa vel'mi jednoducho spojit' s d'alšími ideológiami ako sú liberalizmus, nacionalizmus alebo socializmus a taktiež sa vie prispôsobit' politickej pravici i l'avici (Muro, 2017). Na strane pravice sa využíva nacionalizmus, náboženstvo a etnicita na definovanie jadra populizmu. Strana lavice sa vyznačuje zdôrazňovaním triedneho systému spoločnosti, kde bežní l'udia predstavujú neprivilegovanú skupinu (Aslanidis, 2011), kombinujú tak sociálno-demokratickú ideológiu s populistickým diskurzom a nazývajú samých seba "hlasom l'udu“ (Mudde, 2004; 2007). Inými slovami, možno hovorit' o dvoch typoch populizmu: exkluzívny alebo pravicový populizmus a inkluzívny alebo l'avicový populizmus. Kým prvý sa zvykne objavovat' v bohatých spoločnostiach, $v$ ktorých rastie záujem o migrantov a zahraničné vplyvy, druhý sa častejšie vyskytuje $v$ chudobnejších spoločnostiach $\mathrm{s}$ problémami šíriacej sa korupcie a chudoby (Mudde \& Rovira Kaltwasser, 2012a). 
Kritika tohto prístupu spočiva $v$ definovaní l'udu a najmä dvoch vlastností, ktoré sa mu prisudzujú, a to homogenita a morálna čistota (Katsambekis, 2020). Populizmus ako úzko špecifikovaná ideológia (Mudde, 2004) síce vysvetl'uje dualitu medzi l'ud'mi a elitou, ale jednoznačne nedefinuje, kto je lud a kto elita. $Z$ toho dôvodu sa populizmus často viaže na iné široko špecifikované ideológie, ktoré tento obsah dopíňajú. $U$ pravicového populizmu je to niektorá forma nacionalizmu, u l'avicového populizmu je to niektorá forma socializmu (Mudde, 2007). V prípade nacionalizmu či etnického nacionalizmu v spojení spopulizmom, sú do morálneho protikladu dávané okrem politických elít aj etnické, rasové či náboženské alebo iné kultúrne skupiny či jednotlivci, ktorí sú vnímaní ako hrozba pre l'ud - teda pre skupinu l'udí, ktorá zdiela národnú, etnickú, náboženskú a kultúrnu identitu, ktorú možno označit ako pôvodnú či dominujúcu v danej krajine ${ }^{1}$. $\vee$ prípade Slovenska ide o slovenskú národnost' a etnicitu s krest́anským vierovyznaním, pre ktorú môžu byt́ ostatné etnické skupiny a náboženstvá vnímané ako hrozba. $V$ prípade socializmu sú do protikladu postavené sociálne a ekonomicky privilegované skupiny (elity), ktorých rozhodnutia a konanie odráža vlastné potreby a záujmy, čím predstavujú hrozbu pre neprivilegované sociálne skupiny (bežní l'udia).

Podl'a Katsambekis (2020) je definovanie bežných l'udí ako homogénnej a morálne "čistej“ skupiny v protiklade ku skorumpovanej elite (Mudde, 2004) analyticky obmedzujúce a môže viest' k normatívnemu skresleniu, pretože údajná homogenita a moralistické rámcovanie politiky populistami automaticky vedie $k$ identifikovaniu populizmu ako hrozby voči pluralizmu a liberalizmu, a teda hrozby pre demokratickú spoločnost'. Chybne sa tak populizmus identifikuje s antipluralizmom. Namiesto homogenity, ktorá má pomôct' pri identifikácii so skupinou, navrhuje zamerat' sa na jednotnost' skupiny. Napriek tomu, že v niektorých populistických stranách sa zdôrazňuje boj proti korupcii, neznamená to, že protiklad medzi l'ud'mi a elitou musí nevyhnutne spočívat' v skorumpovatel'nosti. To znamená, že rozdiel medzi l'ud'mi a elitou nemusí byt' len morálny, založený na protiklade dobra a zla. Môže íst́ tiež o politický rozdiel, založený na rozdielnom ideologicko-politickom vnímaní sociálneho rozdelenia spoločnosti alebo na reprezentácii rozdielnych sociálnych a ekonomických

\footnotetext{
1 V prípade etnicky heterogénnych krajín niekedy nehovoríme o dominujúcej, ale o pôvodnej skupine obyvatel'ov, napríklad v Londýne sú v dôsledku migrácie bieli Briti národnostnou menšinou (GOVUK, 2020).
} 
záujmov (Katsambekis, 2020). Jednotnost' skupiny bežných l'udí tak bude spočívat' $v$ ich spoločnom videní sveta a v spoločnom cieli. Klúčovými zložkami populizmu tak ostáva rozdelenie spoločnosti na dve skupiny my a tí druhí, snaha o prinavrátenie politickej suverenity l'ud'om a boj proti elitám, ktorý vyplýva z ich protikladného postavenia.

\section{Populizmus ako komunikačný štýl}

Druhý prístup vychádza z teórie filozofa a politológa Ernesta Laclaua, ktorý definoval populizmus ako diskurzívny politický fenomén, ktorý sa neviaže na špecifickú sociologickú štruktúru, konkrétne sociálne triedy, ideológiu alebo programové vyhlásenie. Vo svojej práci Laclau (2005) uvádza, že „hnutie nie je populistické kvôli svojej politike alebo ideológii, ktorá reprezentuje populistický obsah, ale kvôli tomu, ako je tento obsah prezentovaný, bez ohladu na to, čo je týmto obsahom" (s. 33).

Laclau definuje populizmus vo vztahu k nespokojnosti a frustrácii l'udu z neefektívneho fungovania štátnych inštitúcií a nekonania (politických) elít. Aj v tomto prístupe sú klúčovými charakteristikami l'udia verzus elita, dve homogénne a protikladné skupiny, jedna vykreslená ako pozitívna, druhá ako negatívna. V tomto nazeraní je taktiež dôležitým ciel'om prinavrátenie moci l'udu, aby už d'alej nebola zneužívaná elitami pre ich vlastný prospech. Populisti teda ponúkajú riešenia ako oslabit́ elity, pričom hovoria v mene bežných liudí. Často využívajú manichejský diskurz, ktorý zdôrazňuje rozdelenie spoločnosti na my a tí druhí, teda na bežných l'udí a elitu. $\vee$ komunikácii politikov možno vidiet́ aj preháňanie, podozrievanie a konšpiračné videnie sveta (Gidron \& Bonikowski, 2013). Rozdielom a podobnostiam medzi populizmom či populistickými postojmi a konšpiračným myslením sa podrobnejšie venujeme $v$ tretej kapitole.

Na tento prístup nadväzuje mnoho d'alších prác, ktoré sa zameriavajú na črty diskurzu (pozri napr. Aalberg a kol., 2017; de Vreese a kol., 2018; Jagers \& Walgrave 2007; Rooduijn \& Pauwels, 2011); pohl'ad novinárov a politikov na populizmus v spojení s médiami (Salgado \& Stanyer, 2019; Salgado a kol., 2019; Stanyer a kol., 2019) alebo na populistickú komunikáciu a jej efekt na l'udí (Andreadis a kol., 2019; Corbu a kol., 2019; Hameleers, Andreadis, a kol., 2019; Hameleers, Reinemann, a kol., 2019). Na základe toho, aký obsah a aký štýl sa používa v komunikácii, možno rozlíšit niekol'ko typov populizmu (pozri napr. Aalberg a kol., 2017; Jagers \& Walgrave 2007). 
Kritika pre tento prístup sa zameriava napríklad na meranie tohto javu. Populizmus ako komunikačný štýl je vrôznej miere používaný u pravicových i lavicových politikov, liberálov i konzervatívcov (Kazin, 1995 in Gidron \& Bonikowski, 2013), čo zhoršuje možnost' identifikácie „skutočných" populistov, ktorí sa riadia ideologickými myšlienkami populizmu od nepopulistov, resp. politikov využívajúcich populistickú rétoriku. Vo väčšej miere sa preto vo výskume preferuje miera populizmu v prejavoch (Hawkins, 2009) pred rigidným binárnym označením politika alebo politickej strany ako populistickej. Toto nálepkovanie politikov na dobrých a zlých, vo vztáahu k využívaniu populistickej rétoriky má za následok vytváranie záverov o ich výkone vo vláde, no neexistuje jednoznačné prepojenie medzi používaním populistickej rétoriky a výkonom funkcie (Aslanidis, 2017). V tomto smere možno za rozhodujúce považovat' skôr ich ideologické presvedčenia, teda napr. autoritárstvo alebo liberalizmus, pravicovú alebo l'avicovú politiku.

\section{Populizmus ako politická stratégia}

Tretí prístup nazerania na populizmus navrhol Weyland (2001), ktorý ho definoval ako „politickú stratégiu prostredníctvom ktorej líder vyhladáva a vykonáva moc založenú na priamej, sprostredkovanej a neinštitucionalizovanej podpore zo strany vel'kého počtu zväčša neorganizovaných nasledovníkov“(s. 14). Od predchádzajúceho prístupu sa líši v tom, že sa nezameriava na to, čo populista rozpráva, ale na to, čo robí, aby si získal a udržal politickú moc.

Kým napríklad Weyland aspekt rétoriky z definovania populizmu vynechal, de la Torre (2010) definuje populizmus ako „politickú mobilizáciu založenú na silných rétorických apeloch na ludí a ich činnost' v prospech lídra“ (s. 4). To znamená, že rétorika je úmyselne zvolená a je súčastou stratégie, čím sa tento prístup prepája s predchádzajúcim prístupom.

Moc lídra pramení od bežných ludí, ktorých treba mobilizovat', aby sa mohol dosiahnut' ciel' nazývaný ako „vôla l'udu“ (Weyland, 2017). Táto forma líderstva má dva varianty, jedna je rigidne ideologická - ideokratická, ktorá nie je podl'a Weyland (2017) populistická, a druhá je flexibilná, oportunistická, ktorá sa klasifikuje ako populistická. To znamená, že ak maximalizácia podpory vo forme počtu hlasov ide do popredia pred ideologickou čistotou, vtedy môžeme hovorit' o populizme. 
Ked'sa zameriame na klúčové aspekty populizmu ako politickej stratégie, za centrálnu os tohto konceptu považuje Weyland (2017) kvázi priamy, nesprostredkovaný vztáah lídra a jeho podporovatelov, pričom oslovuje masy najčastejšie prostredníctvom televízie a sociálnych médií, ktoré poskytujú l'ud'om pocit priameho kontaktu s politickým lídrom a umožňujú, aby sa intenzita identifikácie l'udí s lídrom posilnila. Jedným z nástrojov populistických lídrov je antielitárska rétorika, pomocou ktorej môžu ukázat' ludom hrozbu, ktorej čelia a motivovat' ich $\mathrm{k}$ snahe a podniknutiu krokov pre dosiahnutie zmeny. Pritom používajú myšlienky, slogany a kampaň, ktorá sl'ubuje zmenu, no primárnym ciel'om je získat' čo najvyššiu podporu l'udí. Ďalšou z charakteristík, ktorá im pomáha v presvedčení a mobilizácii lúuí je charizma lídra. Nie je to síce definujúca charakteristika, no ak je prítomná, napomáha $k$ l'ahšej identifikácii s lídrom, pričom l'udia vel'mi prirodzene túžia byt súčastou takejto skupiny s odvážnym vodcom, ktorá bojuje proti spoločnému nepriatel'ovi (Weyland, 2017). Príkladom populistickej strany s charizmatickým lídrom na Slovensku je strana HZDS a Vladimír Mečiar či strana Smer-SD a Robert Fico (Lupták \& Lupták Burzová, 2012; Marušiak, 2006).

Podla tejto definície populizmu ako politickej stratégie, sa krajne pravicové, extrémistické strany líšia od populistických práve svojou ideokratickou stratégiou, pričom len tí pravicoví lídri, ktorí sa flexibilne prispôsobujú snahe získat' hlasy, môžu byt' podl'a Weyland (2017) zaradení k populistom. To znamená, že nie všetky pravicové strany sú populistické a vice versa. $A j$ tento prístup má z pohladu zástancov ostatných prístupov určité nedostatky, ktoré sa stávajú predmetom kritiky.

V prípade populizmu ako politickej stratégie od Weylanda, ktorý bol rozpracovaný v kontexte Južnej Ameriky, sú kritizované tri veci: selektívny racionalizmus, zameranie na lídra a normatívne skreslenie (Rueda, 2021). Zjednodušene môžeme povedat', že racionalitu politika, teda či sa primárne snaží získat moc alebo sa snaží získat' moc, aby mohol šírit ideológiu populizmu, nevieme objektívne posúdit. Orientácia na (charizmatického) lídra vedie $\mathrm{k}$ problémom $v$ operacionalizácii, pričom spôsob hodnotenia miery populizmu u lídrov bol spochybnený kvôli svojej nejednoznačnosti pri aplikácii mimo kontext Južnej Ameriky a možným falošne pozitívnym výsledkom. Ďalšou kritikou je normatívne skreslenie, ktoré nás kvôli negatívnej konotácii populistickej stratégie núti vnímat' populizmus ako 
hrozbu pre liberálnu demokraciu, čím sa vytráca objektivita nazerania na populizmus (Rueda, 2021).

Už na základe tohto stručného zhrnutia základných nazeraní na koncept populizmu je vidiet', že sa prístupy do istej miery prelínajú, no majú isté špecifiká. Zároveň z toho vyplývajú značné rozdiely v meraní konceptu a určovaní toho, akého politika alebo akú politickú stranu či hnutie možno alebo nemožno považovat' za populistickú/é. Každý z týchto prístupov je $\checkmark$ rôznej miere používaný $v$ literatúre viacerých vedných odborov pri analýze populizmu v kontexte krajín Latinskej Ameriky, Spojených štátov amerických i Európy, no taktiež sa rozrastá medziregionálny komparatívny výskum (Bos a kol., 2020; Thomas a kol., 2020; Wettstein a kol., 2020) a výskum zameraný na populistické postoje (napr. Akkermanová a kol., 2014; Aslanidis, 2018; Bernhard \& Hänggli, 2018; Hameleers \& de Vreese, 2020).

\section{Príčiny populizmu}

Populizmus je na vzostupe v mnohých industrializovaných krajinách. Príčin je zaiste mnoho, no je dôležité povedat', že ich súhra záleží na národnom kontexte. Podmienky, za ktorých sa do prezidentského kresla dostal Donald Trump v USA zaiste nie sú rovnaké ako tie, ktoré zaručili úspech Marine Le Pen vo Francúzsku, Viktorovi Orbánovi v Mad'arsku, či Robertovi Ficovi na Slovensku. Vo svete, a platí to i pre Slovensko, sa populizmus cyklicky objavuje $v$ časoch, kedy sa spochybňuje fungovanie (demokratického) systému, činnost' vlády a politických inštitúcií (Funke a kol. 2020; Obradović a kol., 2020). Zjednodušene povedané, tam kde je nespokojnost', je aj priestor pre populizmus.

Už zo samotného definovania populizmu, resp. antielitárstva, ktoré je jeho klúčovou charakteristikou vyplýva, že boj proti skorumpovaným elitám je jeho neoddelitel'nou súčastou a teda aj jednou z príčin vzniku. Aj na Slovensku šíriaca sa korupcia, resp. odhalenie mnohých korupčných škandálov politikov a ich politických strán (pozri napr. Bittó Cigániková, 2020; Čikovský, 2015) dopomohlo Igorovi Matovičovi a jeho protikorupčnému hnutiu OL’aNO - Obyčajní l'udia a nezávislé osobnosti, v získaní výraznej podpory v posledných parlamentných vol'bách $v$ roku 2020. Možno teda predpokladat', že rastúca nedôvera voči elitám (Slosiarik, 2019) je aj na Slovensku jedným z determinantov podpory populizmu. 
Medzi príčiny sa často zarad'ujú taktiež ekonomické faktory, najmä globálny ekonomický rozvoj, ktorý podnietil nárast príjmovej nerovnosti medzi l'ud'mi, regiónmi i krajinami (Aiginger, 2020; Gold \& Fetzer, 2019). To súvisí aj so skutočnost́ou, že sa počet l'udí i množstvo investícií sústred'uje do väčších miest, kým menšie či rurálne oblasti ostávajú nefinancované a ich rozvoj stagnuje. To sa zrkadlí napríklad aj na silnej volebnej podpore strany Smer-SD a Roberta Fica (Štatistický úrad Slovenskej republiky, 2020) v okresoch na severovýchode Slovenska (Svidník, Stropkov, Medzilaborce, Vranov nad Topl'ou, Humenné, Snina, Sobrance, Michalovce a Trebišov), ktoré patria medzi najmenej rozvinuté okresy (ÚPSVaR, 2021). Príčinou taktiež môže byt prijímanie nízko kvalifikovaných zamestnancov, tzv. lacnej pracovnej sily z iných krajín (na Slovensku napríklad zo Srbska, Rumunska, Ukrajiny), ktoré medzi určitou skupinou l'udí môže zvýšit pracovnú neistotu a migrácia začne byt' vnímaná ako hrozba pre vlastnú socio-ekonomickú pozíciu. $Z$ toho pramenia aj nesprávne presvedčenia l'udí o migrantoch ako o tých, ktorí nám berú prácu (CEORG, 2015 in Slosiarik, 2019). To potvrdzujú aj výsledky Eurobarometra, podla ktorých majú negatívnejšie postoje $\mathrm{k}$ migrantom l'udia $\mathrm{z} \mathrm{tzv}$. robotníckej triedy oproti respondentom z vyšších sociálnych tried na Slovensku (Bozogáňová \& Lorincová, 2019). Príchod konkurencie, ktorá je ochotná pracovat' za nižší plat a vyšší počet hodín je preto vnímaná ako akcelerátor podpory populizmu (Aigigner, 2020).

Ďalšou príčinou môžu byt' socio-kultúrne faktory, často spájané s migračnou krízou, ktorá vyvoláva u domáceho obyvatel'stva strach. Ide nielen o ekonomické obavy spojené so stratou práce a čerpaním zo sociálneho systému, ale tiež o bezpečnostnú hrozbu (nárast kriminality), zdravotnú hrozbu (šírenie ochorení) a kultúrnu hrozbu (ohrozenie tradícií a kultúry) (CEORG, 2015 in Slosiarik, 2019; Gallo Kriglerová a kol., 2021). Z prieskumov na Slovensku vyplýva, že l'udia negatívnejšie vnímajú utečencov ako ekonomických migrantov alebo cudzincov (Findor a kol., 2021) a taktiež kultúrne vzdialených a menej vzdelaných cudzincov (Gallo Kriglerová a kol., 2021). Socio-kultúrne faktory sa teda viac spájajú s podporou strán, ktoré zastávajú silné antiimigračné postoje.

Ďalšími príčinami môžu byt' kultúrne zmeny, ktoré sa spájajú so zmenami $v$ hodnotovom systéme po vzore západných spoločností, z konzervatívnych na viac liberálne. Liberálne hodnoty sa týkajú napríklad rovnosti pohlaví a akceptácie rôznych foriem spolužitia, ktoré sú v protiklade ku 
konzervatívnemu nazeraniu na tieto otázky (Aigigner, 2020). Podla výskumu Globsec, až 53 \% Slovákov verí tomu, že ich hodnoty a identitu ohrozujú Spojené štáty americké (Hajdu \& Klingová, 2020). Liberálne spoločnosti predstavujú podstatu vzniku populizmu, pretože na rozdiel od liberálov, ktorí chápu spoločnost' ako pluralitnú, populisti vidia spoločnost' čierno-bielo, teda tvorenú l'ud'mi a elitou. Z toho vyplýva aj konflikt medzi demokratickými (rovnost') a liberálnymi (sloboda) hodnotami (Slosiarik, 2019).

Podl'a Tabellini (2019) nárast podpory populistických strán súvisí okrem globálnej finančnej krízy aj s rozšírením sociálnych sietí a médií. Sociálne média facilitujú sprostredkovaný kontakt, redukujú bariéry vstupu nových politických strán do povedomia l'udí a sú schopné vyvolat' emócie, posilnit' stereotypy, skreslit' presvedčenia či mobilizovat l'udí (Bos a kol., 2020). Je zaujímavé, že v štúdii de Vreese a kol. (2019) novinári nevideli média ako k'účový faktor pre vzostup populizmu, na rozdiel od politikov. Novinári aj vedecká obec sa zhodli vimigrácii a ekonomických otázkach na makro úrovni, ale aj národne špecifických otázkach spojených so sociálnou kohéziou $v$ krajine, ako je náboženstvo alebo problematika minorít. $\checkmark$ rovnakej štúdii politici videli príčiny úspechu populizmu v nefungovaní politických inštitúcii vrátane strán, ktoré sú pri moci, no význam individuálnych osobností a charizmy pre atraktivitu a úspech populizmu politici, rovnako ako novinári, odmietali.

\section{Dôsledky populizmu}

Z pohl'adu ekonómov (Funke a kol. 2020; Funke, a kol., 2021) má populizmus ekonomické a politické dôsledky pre spoločnost'. Títo autori pre Slovensko identifikovali dvoch populistov, Vladimíra Mečiara a Roberta Fica, ktorých je možné zaradit' pod pravicový a l'avicový populizmus, $v$ tomto poradí. Na základe analýzy dát pre 60 krajín sveta za posledných 100 rokov potvrdili, že 1) populizmus má dlhú históriu a opakovane sa vracia, pričom $v$ krajinách kde už vládol populista, bude $s$ väčšou pravdepodobnostou populista opät zvolený v budúcnosti, 2) populistické vládnutie je ekonomicky nákladné a má výrazný dlhodobý dopad na pokles spotreby a výkonu, 3) populizmus je aj politicky deštruktívny, napríklad zvyšuje nestabilitu a rozklad inštitúcií a polarizuje spoločnost'. Podrobnejšie sa budeme venovat dvom dôsledkom a to mobilizácii voličov, čo súvisí so skutočnostou, že aj na Slovensku si ludia opakovane volia populistov a taktiež polarizácii spoločnosti. 


\section{Mobilizácia ako dôsledok populistického rámcovania sociálnej identity}

Ak budeme chápat populizmus ako politickú stratégiu, prostredníctvom ktorej chce napríklad politik či politické hnutie mobilizovat' ludí, jedným z prostriedkov v rámci tejto stratégie bude nepochybne aj určitý populistický diskurz. Hlavnou myšlienkou takto definovaného populizmu je poskytnutie rámca na konštruovanie sociálnej identity, a to tým, že zdôrazňuje rozdelenie spoločnosti na dve protikladné skupiny - bežní l'udia verzus elita (Aslanidis, 2016; Mudde, 2004). V súlade s teóriou sociálnej identity (Tajfel \& Turner, 1979), takáto komunikácia vyzýva l'udí k identifikácii so skupinou, ktorej sú prisúdené pozitívne charakteristiky, pričom na udržanie pozitívneho sebaobrazu vlastnej skupiny sú ostatným skupinám (elitám, v prípade pravicového populizmu aj migrantom alebo minoritám) prisúdené negatívne charakteristiky či vina za stav spoločnosti a často sú vnímané ako hrozba pre vlastnú skupinu. Tento rámec je založený na rozdieloch v normách, identitách a záujmoch daných skupín, pričom sa predpokladá vnútorná homogenita skupín a vel'ké medziskupinové rozdiely (Bos a kol., 2020). Takýto diskurzný rámec nemusí byt' používaný len politikmi, taktiež ho môžu používat' novinári v rôznych médiách alebo bežní l'udia vinternetových diskusiách (Aslanidis, 2016). Podla výsledkov experimentu realizovaného v 14 krajinách Európy a v Izraeli, má využívanie rámca v novinovom článku, ktorý obviňuje politické elity zo spoločenských problémov, persuazívne i mobilizačné dôsledky, pričom mobilizovaní boli najmä tí, ktorí sa cítili byt vylúčení (Bos a kol., 2020).

Popri teórii sociálnej identity Tajfela a Turnera (1979) sa na skúmanie mobilizačných dôsledkov populistickej komunikácie využíva aj model sociálnej identity kolektívnych činov (SIMCA - Social identity model of collective action, Van Zomeren a kol., 2008), ktorý funguje najmä pri vnímanej nespravodlivosti a ked' je sociálna identita politizovaná (Bos a kol., 2020, s. 4). Tento model spája tri procesy, ktoré zvyšujú zapojenie sa do kolektívnych akcií, napríklad do protestov, ale aj do volieb. Podl'a tohto modelu sa l'udia aktívne zapoja, 1) aby pomohli zlepšit' postavenie skupiny, ktorej sú členmi (sociálna identifikácia), 2) ak je ich skupina znevýhodnená oproti ostatným skupinám (nespravodlivost') a 3) ked' veria, že svojou aktivitou môžu efektívne zmenit' aktuálny stav (skupinová účinnost') (Thomas a kol., 2020). 
Bežní l'udia sa na základe ich spoločného znevýhodnenia, pozitívneho sebaobrazu a viktimizácie zo strany elít (alebo migrantov, menšín) spájajú, pričom spoločná snaha o dosiahnutie suverenity a antielitárske postoje majú motivačný vplyv pre politickú participáciu (Mudde \& Rovira Kaltwasser, 2012b). Na rozdiel od nedôvery voči politikom a politickým inštitúciám, antielitárske postoje majú morálny charakter, tzn. zvyšujú morálne pobúrenie, ktoré sa pri politickej participácii očakáva. Populistický pohl'ad na politickú elitu je taktiež spojený s emočnými stavmi nabudenia a hnevu. Práve hnev bol potvrdený predchádzajúcimi výskumami ako dôležitejší aktivátor politickej participácie oproti ostatným emóciám (Weber, 2012). V prípade prežívania silných emócií ako je hnev, zdá sa, platí aj opačná kauzalita ako $v$ modeli SIMCA, a teda že viera $v$ účinnost' spoločného konania môže predchádzat identifikácii so skupinou (EMSICA Encapsulated model of social identification and collective action, Thomas a kol., 2012). To znamená, že vnímaná nespravodlivost' a presvedčenie o účinnosti konania môžu viest' k zvýšenej identifikácii so skupinou (bežní l'udia) a k vytvoreniu silnejšieho záväzku - boja proti elitám.

\section{Polarizácia spoločnosti}

Ako uvádza Swoboda a Wiersma (2008) problém populizmu spočíva v definovaní demokracie ako vládnutia väčšiny, pričom jeho pravicová odnož opomína princíp ochrany menšín a jednotlivcov. Populizmus teda nie je antidemokratický, práve naopak, často požaduje posilnenie priamej demokracie. No pravicový populizmus možno považovat' za antipluralistický, čím sa dostáva do rozporu s hlavným princípom liberálnej demokracie. S nárastom populistických a taktiež radikálnych strán sa zvyšuje polarizácia a radikalizácia verejného a politického diskurzu (Schulze a kol., 2020), čo znamená, že sa názory verejnosti aj politikov navzájom dostávajú do výraznej opozície voči sebe.

Niekol'ko rôznych spoločenských tém ako je napríklad podpora migrácie, boj za práva menšín, feminizmus, multikulturalizmus alebo právo na potrat, vytvára živnú pôdu pre populistov a polarizáciu spoločnosti. Taktiež politická nestabilita, nedôvera voči mainstreamovým médiám a politickým stranám, i radikalizácia pravicových i lavicových politických strán vedie k polarizácii strán aj voličov (Schulze a kol., 2020).

Príklad polarizácie spoločnosti možno uviest' na stále aktuálnej téme migrácie. Demografické zmeny spojené s migráciou obyvatel'stva do západnej Európy môžu v etnicky homogénnych a kultúrne konzervatívnych 
krajinách, akou je Slovensko, viest' k obavám a strachu voličov, že ich etnická skupina by mohla byt' utlačená alebo nahradená novou populáciou migrantov (Krastev, 2016). Hrozba, ktorú migrácia môže pre l'udí predstavovat', ako sme už spomínali, nemusí byt' len ekonomického (vplyv na ekonomiku, strata práce) a kultúrneho charakteru (vplyv iných kultúr), ale môže íst' o vnímanú bezpečnostnú (kriminalita $v$ krajine), kohéznu (konflikty vnútri spoločnosti), predsudkovú (zvýšenie xenofóbie) či altruistickú hrozbu (možnost' poskytnutia adekvátnej starostlivosti a služieb) (Landmann a kol., 2019). Vd'aka takýmto obavám sa populistom v rámci centrálnej a východnej Európy darí získavat' podporu ludí. Etnická rôznorodost' a demografické zmeny, ktoré by v dôsledku zvýšenej migrácie nastali, spolu s nedôverou l'ud'om a inštitúciám v krajine, prinášajú medzi ludí napätie a obavy, polarizujú spoločnost' a spolu s populistickými postojmi môžu viest' k obmedzovaniu práv menšín, prehlbovaniu rozdielov vo vnútri spoločnosti, prehlbovaniu nedôvery voči elitám (politickým, spoločenským, mediálnym a ekonomickým), posilňovaniu stereotypov, predsudkov a xenofóbie.

\section{Zhrnutie}

Táto kapitola poukazuje na hodnotovo neutrálne odborné vnímanie pojmu populizmus, ktoré sa líši od negatívneho konotátu, ktorý pojem získal v spoločenskom diskurze. Je dôležité si uvedomit', že vol'né používanie odborných termínov vedie k tomu, že samotný termín stráca svoj skutočný význam. Toto pripomenutie pôvodného významu, definícií a uchopenia populizmu v sociálnych vedách pomáha nielen laickej verejnosti oboznámit' sa s danou problematikou objektívne, ale aj uchopeniu tohto konštruktu $v$ bohato rozvinutom empirickom výskume sociálnych vied.

Kvôli šírke danej problematiky je záber zúžený na tri základné pohlady spoločenských vied - populizmus ako ideológia, komunikačný štýl a politická stratégia. Po tom, čo boli stručne približené rôzne prístupy nazerania na populizmus, ich nedostatky a možné príčiny a dôsledky, je dobré sa presunút od populizmu respektíve populistických politikov $\mathrm{k}$ bežným l'ud'om. Preto sa v nasledujúca kapitola venuje tomu, čo sú to populistické postoje, aké psychologické procesy prebiehajú v pozadí a s akými charakteristikami súvisia. 


\section{KAPITOLA}

\section{POPULISTICKÉ POSTOJE}

V predchádzajúcej kapitole spomínaná nespokojnost' s fungovaním demokratického systému alebo s činnostou vlády, nerovnomerný ekonomický rozvoj regiónov, nárast príjmovej nerovnosti, nárast pracovnej neistoty či zvýšenie strachu a obáv zo sociálno-kultúrnych zmien sa odrazili aj vo volebnom správaní mnohých Európanov.

Výsledky národných parlamentných volieb počas rokov 2017-2020 (ElectionGuide, 2021) vo viacerých európskych krajinách potvrdili silnú podporu populistických strán a ich kandidátov. Dostatočne vysoké percento (uvedené v zátvorkách) pre vstup do parlamentu získali napríklad populistickí lídri pravicových strán - v Mad’arsku Viktor Orbán (Fidesz Mad’arská občianska únia - 49,27 \%), v Taliansku Luigi Di Maio (Hnutie piatich hviezd - 21,54 \%), v Španielsku Santiago Abascal Conde (Vox-15,09 \%), vo Francúzsku Marine Le Pen (Národný front-8,75 \%), ale aj l'avicových strán - v Grécku Alexis Tsipras (Syriza - 31,53\%) ${ }^{1}$, v Španielsku Pablo Iglesias (Spoločne môžeme - 9,8 \%). Taktiež na Slovensku, Roberta Fica, dlhoročného lídra l'avicovej, populistickej, sociálno-konzervatívnej, nacionalistickej strany Smer-SD (18,29 \%) porazilo v parlamentných vol'bách v roku 2020 populistické antikorupčné hnutie Igora Matoviča Ol'aNO $(25,02 \%)$.

Podpora pre populistické strany sa často dáva do súvisu s politickou dôverou (Rooduijn, 2018), externou politickou účinnostou (Rooduijn a kol., 2016), pluralistickými postojmi (Akkermanová a kol., 2014) či spokojnost'ou s fungovaním demokracie (Passarelli \& Tuorto, 2018). V týchto štúdiách sa predpokladalo, že l'udia, ktorí nedôverujú politikom a politickým inštitúciám, vnímajú politický systém ako uzavretý pre l'udí, odmietajú pluralitnú spoločnost' a/alebo sú nespokojní s fungovaním demokracie, budú viac podporovat' populistické strany. Ich schopnost' predpovedat' volebné správanie nebola jednoznačná. Ďalším sluubným vysvetlením boli populistické postoje (Hawkins a kol., 2012; Stanley, 2011). Tie ale napríklad na slovenskej vzorke nevedeli predpovedat' volebné správanie (Stanley, 2011), čo mohlo súvisiet' s tým, že populisti už boli vo vládnej koalícii.

\footnotetext{
${ }^{1}$ Len do roku 2019, kedy sa strana presunula do opozície po tom, čo ju vo vol'bách porazila strana Nová demokracia (39,85\%) (ElectionGuide, 2021).
} 
Taktiež to mohlo súvisiet' s post-komunistickou minulostou alebo aj s nedostatočným zachytením podstaty populistických postojov v položkách použitej metodiky.

Niekol'ko štúdií (napr. Akkermanová a kol., 2014; Geurkink a kol., 2020; Rooduijn, 2019) sa venovalo porovnaniu týchto postojov a ich schopnosti predpovedat' volebné správanie. Podpora pre populistické strany bola vyššia, ak bola politická dôvera nízka a populistické postoje vysoké, no podpora týchto strán nebola vo vztáahu s externou politickou účinnostou. A najmä, len populistické postoje konzistentne vysvetl'ovali volebné preferencie pre krajne pravicové i l'avicové populistické strany (Geurkink a kol., 2020, s. 3). Rovnako vo výskume Rooduijn (2018) sa politickou nedôverou nedala vysvetlit' podpora populistických strán konzistentne naprieč krajinami a časom. To znamená, že l'udia nepodporujú populistické strany a bojujú proti politickým elitám, len preto, že ich dôvera voči nim je nízka a preto, že systém je pre nich uzavretý. Významnejšiu úlohu vo vysvetlení podpory populistických strán zohrávajú práve populistické postoje (Akkermanová a kol., 2014; Geurkink a kol., 2020). Z tohto dôvodu sa táto kapitola venuje práve populistickým postojom bežných l'udí, objasňuje psychologické procesy, ktoré možno sledovat' v pozadí a taktiež charakteristiky, ktoré s nimi súvisia.

\section{Čo sú to populistické postoje?}

Populistické postoje možno definovat' v nadväznosti na základné charakteristiky populizmu ako ideológie (Mudde, 2004) uvedené v predchádzajúcej kapitole. Ak je populizmus definovaný ako ideológia, populistické postoje možno definovat' ako súbor presvedčení l'udí, ktoré sa týkajú nielen myšlienok, ale aj emócií a správania. Z existujúcich štúdii vieme, že ide o multidimenzionálny konštrukt (Castanho Silva et al., 2018, 2020; Schultzová a kol., 2018), pričom autori sa rôznia v niektorých subdimenziách. Ked' pri definovaní populistických postojov použijeme princíp minimálnej definície, môžeme identifikovat' tri klúčové zložky alebo subdimenzie: Prvou je odmietanie elít, teda antielitárstvo (anti-elitism) (Akkermanová a kol., 2014; Castanho Silva a kol., 2018; Oliver \& Rahnová, 2016; Schultzová a kol., 2018), ktoré vyjadruje odmietanie úzkej skupiny politikov profitujúcich z moci a sledujúcich vlastné záujmy.

Druhou zložkou je obhajoba suverenity l'udí (sovereignty of people), ktorá vyjadruje dôležitost́ dosiahnutia zvrchovanosti l'udu (Akkermanová a kol., 2014; Schulzová a kol., 2018), alebo centrizmus l'udí (people-centrism), 
teda zdôrazňovanie centrality l'udí (Castanho Silva a kol., 2018). Táto zložka zahŕňa dôležitost' nasledovania vôle ludí pri prijímaní politických rozhodnutí, $v$ krajnom prípade až odovzdávanie moci do rúk l'ud'om hlasovaním v referende (Schulzová a kol., 2018). Obe zložky úzko súvisia s kritikou aktuálnej politiky a vyplývajú z vnímaných rozdielov medzi l'ud'mi a elitou.

Tretou zložkou a subdimenziou populistických postojov je Manichejské vnímanie (Manichean Outlook) (Akkermanová a kol., 2014; Castanho Silva a kol., 2018). Ide o čierno-biele videnie usporiadania spoločnosti, v ktorej existuje len elita a lud, dobrí a zlí, priatelia a nepriatelia. Takýto schematický obraz spoločnosti zjednodušuje politiku a je zrozumitel'ný aj pre l'udí, ktorí sa nezaujímajú o politiku alebo jej nerozumejú (Mudde, 2004). Aj ked'vnímame, že spoločnost' tvoríme len my (tí dobrí) a tí druhí (tí zlí), môžeme sa medzi sebou lísití v tom, koho vnímame ako súčast' týchto skupín.

S tým súvisí d’alšia dimenzia populistických postojov, ktorá sa zvykne uvádzat' vo výskume sociálnych vied, a to homogenita l'udu (homogeneity of people) (Schulzová a kol., 2018), ktorá sa dáva aj do vztahu s národnou afiliáciou (Oliver \& Rahnová, 2016). Tá umožňuje bližšie definovat' postoje súvisiace s vnímaním vlastnej skupiny (my) ako takej, ktorá zdiela rovnaké hodnoty a záujmy, spôsob myslenia, ale aj národnú príslušnost' (Schulzová a kol., 2018). Problém to predstavuje pri l'avicovom populizme, kde sú ludia vyzývaní bojovat' voči sociálnym elitám, no nemusia byt' homogénnou (z národnostného či etnického hl'adiska) a morálne čistou skupinou (Bonikowski a kol., 2018). Mali by byt' ale jednotní na základe spoločného ciel'a a jednotného nazerania na usporiadanie spoločnosti. Takýmto ciel'om je porazenie elít (antielitárske postoje) a dosiahnutie toho, aby politika vychádzala zo záujmov a potrieb l'udu (suverenita l'udí). Antipluralizmus (anti-pluralism) v tomto kontexte prebieha $v$ dvoch rovinách. Na úrovni politických strán sa populisti prezentujú ako jediní legitímni zástupcovia l'udu a všetci ostatní sú vylúčení prinajmenšom na základe morálky. Ideálnym výsledkom je tak autokratické vládnutie namiesto demokratického. Druhá rovina sa týka ludí samotných, a teda znamená odmietanie diverzity $v$ spoločnosti a tých, ktorí nezdiel'ajú tieto populistické postoje.

Táto charakteristika nie je zaradená do minimálnej definície, pretože prítomnost' antipluralistických presvedčení, etnickej a 
národnej homogenity $v$ rovine l'udí sa viaže skôr na pravicový populizmus. Ak napríklad medzi tých druhých, ktorí nás ohrozujú patria nielen politické elity, oligarchovia, ale aj menšiny, migranti a/alebo l'udia odkázaní na pomoc, možno to vnímat' ako exkluzivistický, pravicový populizmus. Ten zvykne znevažovat' práva menšín, podporuje nacionalizmus a vyznačuje sa netolerantnými postojmi voči týmto skupinám. Ak je ale skupina l'udu definovaná aj ako skupina menšín, migrantov, či l'udí odkázaných na pomoc, pričom nie je vnímaná ako hrozba, možno hovorit o inkluzivistickom l'avicovom populizme. Ten pomáha chránit' práva menšín a prejavuje sa tolerantnejším vnímaním spoločnosti (Katsambekis, 2020, s. 10). Na základe uvedeného možno ostatné charakteristiky populizmu chápat' ako doplňujúce, pričom podl'a toho ako široko je definovaná skupina elít a skupina luudu, možno určit o ktorý typ populistických postojov ide. Viac informácií k spôsobom operacionalizácie a meraniu populistických postojov uvádzame $v$ štvrtej kapitole.

\section{Sociálno-psychologické vysvetlenia populistických postojov}

Dôležitost' psychológie pre porozumenie populistických postojov zdôrazňujú v štúdii Obradović a kol. (2020), ktorí sa venujú trom hlavným oblastiam: 1) sociálnej kategorizácii a medziskupinovej dynamike, ktoré vysvetl'ujú rozdelenie spoločnosti na my a tí druhí; 2) ekonomickým a kultúrnym procesom, ktoré sú koncipované z pohladu sociálnej hierarchie a obáv zo straty statusu a 3) kolektívnym emóciám, ktoré majú mobilizačné účinky. Bližšie si približime všetky tri oblasti.

Sociálna psychológia sa na tému populizmu díva cez optiku interakcií medzi jednotlivcom a spoločnostou, pretože práve dichotómia medzi bežnými l'ud'mi a elitou podčiarkuje ako pravicový, tak i l'avicový populizmus. Koncept sociálnej identity Tajfela a Turnera (Tajfel, 1974; Tajfel \& Turner, 1979) je dôležitým pojmom psychológie pre vysvetlenie medziskupinových vztáahov nielen v kontexte témy populizmu. Sociálna identita, ktorá je definovaná ako „čast' konceptu seba, ktorá vychádza z uvedomovania si svojho členstva v sociálnej skupine spolu s emocionálnou väzbou $k$ tomuto členstvu“ (Tajfel, 1974, s. 69), je klúčcovou pre naše vnútro- a medziskupinové správanie. Osoba sa začne správat' ako súčast' skupiny (bežní l'udia), ked' vd'aka vnímaniu svojej sociálnej identity dôjde $\mathrm{k}$ depersonalizácii, teda $\mathrm{k}$ stavu, kedy sa osoba identifikuje viac ako súčast' skupiny, než ako jednotlivec. $K$ tomu dochádza vtedy, ak členstvo $v$ tejto skupine spĺña jej očakávania, hodnoty, motívy a potreby. Zároveň rozdiely 
vo vnútri skupiny (bežní l'udia) musia byt' vnímané ako menšie v porovnaní s rozdielmi medzi skupinami (bežní l'udia a elita) (Aslanidis, 2018).

Je dôležité rozlišovat' tri klúčové strany, ktoré sa na tomto procese podiel'ajú, a to politikov/politické strany, média a občania, ktorí predstavujú komunikátorov a rámcujú sociálnu identitu skupín (de Vreese a kol., 2018; Hameleers, Reinemann a kol., 2019). Práve komunikácia určitých aspektov vlastnej identity cez média a politikov zvyšuje vnímanú dôležitost' daného aspektu vlastného ja, čo pomáha l'ud'om sa identifikovat' s danou správou a jej obsahom. Psychologické procesy ako je kognitívny priming, stereotypizácia a prisudzovanie viny (Hameleers, Reinemann a kol., 2019) pomáhajú formovat' odpoved' ludí na populisticky rámcované informácie. Zvyčajne ide o prezentované ohrozenie zo strany iných skupín a pripisovanie viny tejto skupine/skupinám, ktorú reprezentujú bud' ekonomické či politické elity alebo sú to cudzinci, migranti a podobne (napr. Bos a kol., 2020). Politici prezentujú verejne svoj záujem o rôzne definované skupiny (napr. ekonomicky, kultúrne) a taktiež snahu pomôct' im a reprezentovat' ich záujmy. Pozornost' upriamujú na problémy l'udí v spojení s témami ako migrácia, príjmové rozdiely a podobne, čím ponúkajú l'ud’om vinníka za ich problémy a aj prípadné riešenia.

$\mathrm{Na}$ to všetko, teda na často prezentované rozdelenie spoločnosti na elitu a l'ud, existenciu konfliktu medzi skupinami a prisudzovanie viny iným za problémy l'udí či štátu, reagujú lúdia v rovine kognícií, emócií, postojov a správania.

V rovine kognícií sú presvedčení o hrozbe, deprivácii a zároveň o vinníkoch vlastnej situácie či situácie v krajine (Hameleers, Reinemann a kol., 2019). Bežní ludia sú, podla jedného z využívaných pohladov, definovaní na základe vertikálnej a horizontálnej opozície kostatným skupinám (Brubaker, 2017 in Obradović a kol., 2020). Vertikálna opozícia vyjadruje rozdiel medzi bežnými l'ud'mi a elitou, pričom sa viac zameriava na politické a ekonomické rozdiely, ktoré sú príznačné pre l'avicový populizmus. Horizontálna opozícia je definovaná cez rozdiely medzi kultúrnymi a etnickými skupinami (napr. cudzinci, migranti) vnútri spoločnosti aj medzi spoločnostami, čo je charakteristické pre pravicový populizmus. Takto definovaná spoločnost' nám umožňuje pochopit' ako sa pre bežných ludí v strede tejto hierarchie stávajú l'udia z vrchných a spodných priečok hrozbou. Úspech populistických strán tak spočíva v schopnosti 
kategorizovat' spoločnost' takým spôsobom, aby zachytili existujúce skupiny, zjednotili ich podl'a spoločnej identity s ciel'om vyriešit' konflikt a zahnat' hrozbu, ktorá podla nich existuje, pričom vodca danej strany sa stáva prototypom človeka z l'udu (Obradović a kol., 2020).

V tomto nazeraní je dôležitým konceptom obava o stratu statusu, pretože práve táto strata či pokles $v$ rámci hierarchie môže byt vnímaná ako ohrozujúca. To spúšta snahu o získanie kontroly nad situáciou (Fritsche a kol., 2017) a súvisí s podporou pravicového populizmu (Gidron \& Hall, 2017). Ked'sa l'udia cítia byt' ohrození, ich politické názory sú viac pravicové, autoritárske, čo je evolučne zakorenená reakcia na ochranu seba (Lewis \& Bates, 2013). Pravicové populistické hnutia rétorikou my a tí druhí, zdôrazňovaním hrozby (napr. zo strany migrantov) oživujú nervové mechanizmy evolučnej túžby byt' súčastou skupiny a inštinkt vyhnút sa hrozbe (Kurzban \& Leary, 2001).

$\checkmark$ tomto kontexte sa prepája ekonomická $s$ kultúrnou hrozbou, pričom l'avicový populizmus mobilizuje skôr chudobných a etnicky marginalizované skupiny a pravicový skôr bohatých a etnickú majoritu (Gidron \& Hall, 2017). To pomáha vysvetlit' aj skutočnost', že populistické strany si získali podporu od l'udí z rôznych socioekonomických skupín a taktiež v časoch ekonomickej prosperity i úpadku. $V$ čase ekonomického úpadku je jednoduché vinit' z tohto stavu ostatných (elity, oligarchov, migrantov) a v čase prosperity štátu je problémom, ak prosperuje len malá čast' spoločnosti (elity, oligarchovia) (Jetten, 2019 in Obradović a kol., 2020).

Dobrým príkladom toho, že podpora populizmu je závislá aj na širšom kontexte, vktorom sa odohráva, sú výsledky prieskumu YouGov Cambridge Globalism Project (Henley \& Duncan, 2020), ktorý bol zameraný na rozdiely $v$ populistických presvedčeniach ludí medzi rokmi 2019 (pred pandémiou) a 2020 (počas pandémie) v rámci 25 krajín sveta. Výsledky ukázali značný pokles v populistických presvedčeniach vo všetkých ôsmich európskych krajinách, ktoré boli zapojené. Ako uvádza Rooduijn (in Henley \& Ducan, 2020) ohrozenie, ktoré so sebou pandémia koronavírusu prináša, zdá sa, pôsobí na naše postoje. Jednak na vyššiu dôveru voči odborníkom, politikom, či expertom (elitám), pretože pandémia nepredstavuje situáciu, kedy chceme vrátit' moc do rúk l'udí, no taktiež na vyššiu podporu zníženia migrácie, ktorá môže predstavovat' zdravotné riziko. Zároveň sa šírením dezinformácií a konšpirácií vytvára priestor pre populistov, ktorí môžu 
využívat' tieto inštinkty či evolučné mechanizmy k zvýšeniu vlastnej podpory.

Vemocionálnej rovine sa ludia cítia ohrození, majú strach a obavy, prípadne prežívajú hnev, ktorý sa ukazuje ako významný prediktor pre podporu populistických strán (Marcus, 2021; Rico a kol., 2017, 2020). Postoje k vlastnej skupine sa môžu ešte viac posilnit alebo sa polarizujú ich postoje k ostatným skupinám, ktoré sú vnímané ešte viac homogénne, čo sa spája s predsudkami a negatívnymi postojmi voči týmto skupinám (Hameleers, Reinemann a kol., 2019). Práve toto prisudzovanie viny je silným prediktorom pre populistické postoje (Hameleers a kol., 2016 in Hameleers, Reinemann a kol., 2019).

Čo sa týka správania, výsledkom môže byt' ich mobilizácia, jednak v zmysle zdielania takejto informácie, $v$ ktorej sú $z$ problémov l'udí obvinené elity (Bos a kol., 2020), ale aj v zmysle volebného správania alebo účasti na demonštráciách (Hameleers a kol., 2017). Mechanizmus, ktorým sa vysvetl'uje význam populistického rámca prisudzovania viny na volebné správanie l'udí spočíva $v$ tom, že sa l'udia rozhodnú, kto by mal byt potrestaný a kto odmenený vo vol'bách, čím sa znízi preferencia dat' hlas koaličným stranám (Hameleers a kol., 2017). Výskumy totiž potvrdili, že ak sú l'udia vystavení populistickej komunikácii, s väčšou pravdepodobnostou budú hlasovat' pre populistické strany (Bos a kol., 2020, Hameleers a kol., 2017). Okrem týchto krátkodobých dopadov (e.g., Bos a kol., 2020; Wirz, 2018) môže mat́ populistický rámec používaný politikmi a médiami aj dlhodobý dopad, a to napríklad na polarizáciu spoločnosti, ktorá bola popísaná v predchádzajúcej kapitole ako jeden z možných dôsledkov populizmu.

\section{Predispozície l'udí pre populistické postoje}

Vneposlednom rade je potrebné vediet', kto je na populistickú komunikáciu viac senzitívny, resp. aké sú predispozície pre to, aby sa človek nechal presvedčit' prípadne aj mobilizovat komunikovaným populistickým obsahom. Nakol'ko socioekonomické charakteristiky môžu ovplyvňovat' rozsah do ktorého sú jednotlivci zahrnutí do politického systému, populizmus je prítažlivý najmä pre marginalizovaných alebo vylúčených (Mudde \& Rovira Kaltwasser, 2017). To korešponduje aj s hlavnou myšlienkou populizmu, ktorou je vrátit' „priemerného“ občana do politického záujmu a vrátit' hlas l'ud'om, ktorí sa necítia byt' reprezentovaní politickou elitou. Sú to teda l'udia, ktorí predstavujú bežných l'udí, ktorí sami 
seba vnímajú ako ukrátených či znevýhodnených tým, akým spôsobom sa vykonáva politická moc a koho záujmy sú sledované, čo je často vnímané mimo ich kontroly. Z výskumov vyplýva, že existuje pozitívny vztah medzi výškou príjmu, kvalifikácie a vzdelania a populistickými postojmi, pričom menej zarábajúci, menej kvalifikovaní a menej vzdelaní respondenti dosahovali vyššie skóre v populistických postojoch (Boscán a kol., 2018). Rozdiely boli ale zistené aj v tom, či podporovali skôr populistickú pravicu alebo l'avicu. Viac i menej vzdelaní respondenti a tí, čo sa identifikujú ako pracovná trieda (Ramiro, 2016) alebo nezamestnaní (Visser a kol., 2014), podporujú viac radikálnu l'avicu, čo sa spája s ich záujmom o zníženie príjmových rozdielov medzi l'ud'mi. Muži, v porovnaní so ženami, podla výskumov viac podporujú radikálnu pravicu (Spierings a kol., 2015; Spierings \& Zaslove, 2015). Rodové rozdiely vpodpore pravicových populistických strán sa vysvetl'uje v literatúre dvojako: 1) tým, že muži a ženy zastávajú rozdielnu socio-ekonomickú pozíciu, teda že ženy sú častejšie zamestnávané vo verejnom sektore a sú menej ohrozené industrializáciou; 2) postojmi, najmä voči migrácii, teda, že ženy sú menej ohrozené migráciou, lebo migranti pre ne nepredstavujú priamu hrozbu (Spierings \& Zaslove, 2015; 2017). Medzi d'alšie atribúty, ktoré boli potvrdené ako súvisiace stým, u koho možno predpokladat' podporu populistických strán, bola zaradená podpora extrémnej pravice alebo l'avice. To znamená, že voliči, ktorí inklinujú k extrémne pravicovým alebo extrémne l'avicovým stranám, budú viac inklinovat' $k$ populistickej rétorike ako voliči stredových strán (Pelinka, 2008).

Vostatnom období rastie záujem spoločenských vied aj o možné psychologické vysvetlenia populistických postojov. Potvrdeným a často uvádzaným ako jeden z hlavných korelátov populistických postojov je aj inštitucionálna či politická dôvera (Erisen a kol., 2021). S nižšou dôverou v národné inštitúcie $v$ Taliansku aj Turecku stúpla úroveň populistických postojov, resp. ich dvoch zložiek - centrizmu l'udí a antielitárstva. $\mathrm{Na}$ Slovenku až 70 \% Slovákov v reprezentatívnom zbere z roku 2020 (Hajdu \& Klingová, 2020) vyjadrilo nedôveru voči politickým stranám na Slovensku, čo súvisí s ich nespokojnostou s fungovaním demokracie a presvedčením, že nezáleží na tom kto vládne, pretože sa aj tak nič nezmení. Možno predpokladat', že politická a inštitucionálna dôvera by aj na Slovensku zohrávala vel'kú rolu vo vysvetlení populistických postojov l'udí. 
V štúdii Erisen a kol. (2021) boli zvažované napr. potreba poznania, viera v jednoduché riešenia problémov, morálny záväzok a taktiež konšpiračné myslenie. $V$ prípade potreby poznania sa predpokladá, že tí, ktorí majú nízku potrebu poznania uprednostňujú povrchné myslenie o informáciách, s ktorými sa stretnú, zvažujú menší počet dimenzií a formujú svoj úsudok na základe povrchného vyhodnotenia informácií, bez väčšej námahy a premýšl'ania. Práve takéto zjednodušené myslenie môže byt' spojené s vnímaním spoločnosti rozdelenej na priatel'ov a nepriatelov (Erisen a kol., 2021). Viera $v$ jednoduché riešenia pomáha l'udom vysporiadat' sa s neistotou a strachom, čo môže súvisiet' aj s d'alšou charakteristikou, a tou je vyhýbanie sa neistote a taktiež podpora jednoduchých riešení na zložité problémy, ktoré navrhujú populisti. Morálny záväzok v tomto kontexte súvisí spresvedčením, že neetické správanie je akceptovatel'ným prostriedkom na dosiahnutie želaného výsledku, pričom l'udia s nízkym skóre v tejto charakteristike sa cítia menej vinní za svoje činy (Erisen a kol., 2021). Potvrdeným korelátom populistických postojov pre taliansku i tureckú vzorku v tomto výskume (Erisen a kol., 2021) bolo konšpiračné myslenie (a dôvera), ktorému sa podrobne venujeme $v$ nasledujúcej kapitole.

Hameleers, Reinemann a kol. (2019) spomedzi psychologických faktorov v rámci výskumu uvádzajú relatívnu depriváciu, teda vnímanie vlastnej skupiny ako vhoršej pozícii oproti ostatným skupinám v spoločnosti; a pripútanie kskupine, resp. silnú národnú identitu, ktorá hrá rolu v prisudzovaní viny ostatným skupinám.

Spomedzi hodnôt môže mat' pre podporu populistických strán význam napríklad sociálna dominancia, ktorá vyjadruje rozsah do akého jednotlivec podporuje rozdiely medzi sociálnymi skupinami (Wright \& Esses, 2019). Spomedzi základných l'udských hodnôt potvrdil vo výskume Marcos-Marne (2021) negatívny vztah tradície a konformity pre vol'bu l'avicových i pravicových populistických strán. S vol'bou pravicových strán súvisela vyššia dôležitost' hodnoty bezpečia a nižšia dôležitost' univerzalizmu (záujem, tolerancia a ochrana blaha všetkých l'udí i prírody).

U populistov sa často zdôrazňuje aj vyvolávanie emócií za účelom presvedčenia l'udí, čo bolo aj výskumne potvrdené (Wirz, 2018). Často skúmanou spomedzi emócií na strane lúudí je hnev a strach (Marcus, 2021; Rico a kol., 2017, 2020), či hrozba - bezpečnostná, ekonomická, kultúrna (Wright \& Esses, 2019), ktoré pomáhajú mobilizovat l'udí. 
Taktiež bol potvrdený význam vlastného presvedčenia, že jedinec je kompetentný porozumiet' a participovat' v politike pre populistické postoje, čo bolo nepriamo zvyšované pocitmi hnevu (Rico a kol., 2020). To súvisí aj s presvedčením, že bežní l'udia by mohli túto prácu robit' lepšie ako politici.

Výskum zacielený na význam osobnostných charakteristík pre populistické postoje ludí potvrdil význam viacerých čŕt s rozdielmi medzi krajinami (Spojené král'ovstvo, Nemecko) (Fatke, 2019). Kým svedomitost' (opatrný, spol'ahlivý, svedomitý) a extraverzia (spoločenský, spontánny, vel'avravný) bola vo vztahu s podporou populistov v Nemecku, otvorenost' zmene (originálny, odvážny, liberálny) bola potvrdená v Anglicku. V oboch krajinách sa potvrdil význam prívetivosti (súcitný, srdečný, nesebecký). Aj v d'alšej štúdii na vzorke Holand'anov, Američanov a Nemcov sa potvrdil význam nízkej úrovne prívetivosti pre vol'bu populistických strán (Bakker a kol., 2015). Spomedzi charakteristík tzv. temnej triády (Dark triad), boli na španielskej vzorke potvrdené psychopatia (nízka miera empatie, sebavedomia a úzkosti a vysoká impulzivita) a Machiavelizmus (cynickost', manipulatívnost', amorálnost') ako negatívne spojené s populistickými postojmi, kým narcizmus bol ako jediný v pozitívnom vztahu s jednou dimenziou populistických postojov - centrizmus l'udí, teda presvedčením, že l'udia majú byt' v centre politického záujmu (Galais \& Rico, 2021). Taktiež na kanadskej vzorke boli potvrdené tri osobnostné charakteristiky a to: čestnost'-pokora, emocionalita a svedomitost', spomedzi temných vlastností to bol taktiež narcizmus, ktorý bol na rozdiel od výsledkov predchádzajúceho výskumu v negatívnom vztáahu, tzn. že vyššia hodnota narcizmu sa spájala s nižšou mierou populistických postojov (Pruysers, 2020). Pre podporu pravicových populistických strán sa okrem sociálnej dominancie v Nemecku potvrdil aj negatívny vztah podpory pravicového populizmu a narcistického obdivu (asertívna sebaprezentácia) a pozitívny vzt́ah narcistickej rivality (antagonická sebaochrana) a autoritárskych hodnôt (pasívne podriadenie sa autoritám a normám, podpora tradičných noriem a hodnôt, sociálneho usporiadania a stability a agresívne vnímanie tých, ktorí sa od týchto noriem vzd'al'ujú), ktoré boli posilnené protiimigračným postojmi (Mayer a kol., 2020). Z uvedených výskumov vyplýva, že nielen negatívne či problematické osobnostné charakteristiky sa spájajú s populistickými postojmi l'udí, aleTaj výsledky sú závislé aj na národnom kontexte. 
Podla autorov Hameleers, Reinemann a kol. (2019) zohrávajú rolu aj informačné faktory, ako je vnímanie a využívanie médií. Teda napríklad, čítanie bulvárnych alebo dezinformačných médií, ktoré formujú naše postoje, emócie a správanie. $V$ neposlednom rade sú to aj faktory na úrovni štátu ako je ekonomická situácia vkrajine, stav migrácie, úspech populistických strán a úroveň inštitucionálnej dôvery v krajine (Hameleers, Reinemann a kol., 2019). Tie môžu ovplyvňovat' to, či sa l'udia dajú presvedčit populistickou komunikáciou alebo voči nej ostanú rezistentní. Síce možno predpokladat', že v krajinách s vyššou príjmovou nerovnostou budú l'udia viac podporovat' populistickú l'avicu, vo výskume Visser a kol. (2014) bola podpora pre populistickú l'avicu nižšia, ak boli v krajine vyššie ekonomické rozdiely medzi l'ud'mi, pričom vyššiu podporu pre radikálnu l'avicu mali l'udia z krajín, ktoré majú skúsenost' s autoritárskym režimom.

\section{Zhrnutie}

Výsledky realizovaných výskumov potvrdzujú opodstatnenost' skúmania populistických postojov, ktorá súvisí so silnejúcou podporou populistických strán naprieč Európou. Existujú ale rozdiely v definovaní populistických postojov a ich operacionalizácii vo výskume. V kapitole uvádzame subdimenzie populistických postojov, ktoré možno považovat' podla minimálnej definície za klúčové, a to antielitárske postoje (anti-elitist attitudes), centrizmus l'udí (people-centrism) a manichejské vnímanie usporiadania spoločnosti (Manichean Outlook). Ďalšími sú antipluralizmus (anti-pluralism) či homogenita l'udu (homogeneity of people). V kapitole sú popísané kognitívne procesy z teórie sociálnej identity Tajfela a Turnera (1979), ktoré pomáhajú vysvetlit populistické postoje. Ide najmä o sociálnu kategorizáciu (zarad'ovanie l'udí do sociálnych skupín), sociálnu identifikáciu (identifikovanie sa so skupinou) a sociálne porovnávanie (priaznivé hodnotenie vlastnej skupiny oproti ostatným). Podstatným pre porozumenie zvýšenej podpory populistických strán sa javí identifikovanie osobných, sociálnych a psychologických charakteristík, ktoré súvisia s vyššou pravdepodobnostou, že človek má populistické postoje. V kapitole sú uvedené výsledky mnohých zahraničných výskumov, z ktorých vyplýva okrem iného aj dôležitost' národného kontextu. Nakol'ko je výskum tejto témy z pohl'adu sociálnej psychológie na Slovensku absentujúci, je dôležité sa venovat́ tejto téme aj $v$ našich podmienkach a výskumne potvrdit' alebo vyvrátit' význam daných charakteristík pre populistické postoje slovenskej populácie. 


\section{KAPITOLA}

\section{POPULISTICKÉ POSTOJE VS. KONŠPIRAČNÉ MYSLENIE}

\section{Čo sú to konšpiračné teórie?}

Diskusia o vzt́ahu medzi populistickými postojmi a konšpiračnými teóriami si v prvom rade vyžaduje definovanie niektorých klúčových pojmov. Pojem konšpirácia sa dá definovat' ako tajné sprisahanie medzi dvoma alebo viacerými mocnými aktérmi (Keeley, 1999). Konšpirácie alebo konšpirátori sa typicky pokúšajú uzurpovat' politickú alebo ekonomickú moc, porušovat' l'udské práva, zatajit' významné informácie a menit'/ničit' ustanovené inštitúcie (Douglas a kol., 2019).

Nadväzne na túto definíciu môžeme konšpiračné teórie (KT) definovat' ako pokus vysvetlit' dôležité sociálne a politické udalosti tajným sprisahaním viacerých mocných aktérov. Autori Sunstein a Vermeule (2009) teoretizujú, že viera v KT je spôsobom pre určitú skupinu l'udí, ktorí sa cítia bezmocní a znevýhodnení, ako si vysvetlit' inak tažko uchopitel'né udalosti, napríklad teroristické útoky.

Ďalším dôležitým termínom je viera $\mathbf{v}$ konšpiračné teórie respektíve konšpiračné presvedčenie. Tieto termíny odkazujú na vieru, že špecifická KT alebo viacero KT sú pravdivé. Príkladom takejto viery je napríklad presvedčenie, že Johna $\mathrm{F}$. Kennedyho zabila CIA, čo si myslí $60 \%$ Američanov (Enders \& Smallpage, 2018). Ďalším príkladom je, že $46 \%$ z tých, ktorí v roku 2016 v referende o členstve Spojeného Král'ovstva v Európskej únii (EÚ) hlasovali o vystúpenie verili, že vol'by budú aj tak zmanipulované (Drochon, 2018).

Súvisiacim termínom je tiež konšpiračné myslenie, ktoré môžeme definovat' ako celkovú tendenciu verit' v KT (Imhoff \& Bruder, 2014). Existenciu takého myslenia podporujú zistenia, že l'udia veriaci v špecifickú KT sú náchylnejší uverit' aj iným KT (Goertzel, 1994), hoci spolu nesúvisia alebo si navzájom dokonca odporujú (Wood a kol., 2012). Takéto zistenia môžu naznačovat' tendenciu niektorých l'udí preferovat' konšpiračné vysvetlenia udalostí pred konvenčnými vysvetleniami na základe odporu k určitým (často elitným) skupinám a oficiálnym autoritám (Imhoff \& Lamberty, 2018). 
Posledným dôležitým termínom je označenie konšpirátor. Toto označenie sa používa v dvoch významoch. V prvom význame je konšpirátor osoba, ktorá verí v určitú $\mathrm{KT}$ a má silnú tendenciu ku konšpiračnému mysleniu. V kontexte druhého významu je konšpirátor osoba, ktorá úmyselne a vedome rozširuje a propaguje $\mathrm{KT}$, často profesionálne alebo za účelom dosiahnut' politické alebo iné ciele (Douglas a kol., 2019).

KT sa väčšinou vyznačujú niekol'kými klúčovými charakteristikami. Podla autorov van Prooijena a van Vugta (2018) existuje prinajmenšom pät' kritických znakov. Po prvé, KT predpokladajú kauzálnu spojitost' medzi osobami, objektami a udalost'ami. Inak povedané, spravidla navrhujú určitý vzorec spojitostí. Po druhé, KT špecifikujú, že plány zúčastnených konšpirátorov sú vedomé, plánované, účelové a slúžia konkrétnej agende. Tretím znakom je, že KT vždy zahrňujú koalíciu aktérov, ktorá pracuje spoločne na dosahovaní agendy. Táto koalícia zvyčajne zahŕňa mocné skupiny ako napríklad spoločenských vodcov, vládne inštitúcie (populárne sú najmä tajné služby), vplyvné odvetvia priemyslu (ropný či farmaceutický priemysel) a stigmatizované minority (Moslimovia, Židia). Tieto skupiny spravidla konšpirujú proti ostatným vrstvám spoločnosti. Po štvrté, KT obsahujú element ohrozenia, napríklad v kontexte ciel'ov konšpirátorov, ktorých naplnenie má pre inú skupinu deštruktívny dopad. Piatym, posledným a vel'mi podstatným znakom KT je element utajovania, tajnosti, ktorý do určitej miery st'ažuje ich dokazovanie. Element tajnosti je podla autorov Dentitha a Orra (2017) kl'účovou ingredienciou konšpirácie, ked'že ponúka lákavý, atraktívny aspekt (tajomstvo známe len niektorým vyvoleným) a zároveň ponúka pocit výnimočnosti (medzi vyvolených patrím aj ja).

Napriek definujúcim charakteristikám majú KT značný obsahový záber a vyznačujú sa nekončiacou rozmanitost́ou. Preto je pre ich jasnejšie pochopenie nevyhnutné ich rozdelit' do určitých kategórií. Barkun (2013) ponúka kategorizáciu, ktorá diferencuje tri typy na základe šírky a dosahu daných teórií. Prvá kategória KT ponúka alternatívne vysvetlenia určitých izolovaných udalostí (napríklad smrt́ princeznej Diany či zámerné šírenie vírusu AIDS). Druhá kategória obsahuje KT širšieho dosahu, tie, ktoré spravidla popisujú snahu „zlých síl“ o kontrolu nad l'ud'mi a krajinami alebo o infiltráciu a rozklad inštitúcií a spoločností. Tretia kategória je kategória takzvaných "superkonšpirácií“, ktoré hierarchicky spájajú niekol'ko KT a vysvetl'ujú takmer celé fungovanie sveta pôsobením všemocnej zlej sily. 
Ďalším rozdelením je obsahová kategorizácia vymedzujúca napríklad medicínske a politické KT. Medicínske KT pritom vypovedajú o vplyve odvetví medicíny a farmaceutického odvetvia a politické KT vypovedajú o vplyve vlády, vládnych inštitúcií a politických aktérov (Galliford \& Furnham, 2017). Politické KT, ich vztah s populistickými postojmi a ich fungovanie vo svete politiky sú primárnym zameraním tejto kapitoly.

\section{Populárne politické konšpiračné teórie}

Uvádzame niekol'ko historicky a súčasne populárnych KT relevantných najmä $\vee$ politických súvislostiach, respektíve často zneužívaných na politickú propagandu najmä populistickými politikmi.

Antiislamské KT. V Európe aj Amerike sú značne rozšírené KT o Islame a Moslimoch infiltrujúcich západné krajiny. Spomedzi týchto teórií má výsostné miesto $\mathrm{KT} s$ názvom Eurabia, ktorá tvrdí, že EÚ je projekt vytvorený moslimami a domácimi európskymi elitami, s ciel'om kultúrne transformovat' kontinent na takzvanú Eurabiu - islamskú spoločnost́. Zástancom a šrírel'om Eurabie bol aj nórsky masový vrah Anders Breivik, ktorý sám seba opisoval ako krestáanského rytiera čeliaceho moslimskej vlne v Európe. 22. júla 2011 na základe svojich presvedčení zabil 77 l'udí. Avšak antiislamské a podobné antiimigrantské KT a presvedčenia sú vlastné ovel'a širšej vrstve spoločnosti ako sú len teroristi. Predseda holandskej Strany pre slobodu Geert Wilders sa vyjadril, že holandský lud je postupne nahradzovaný zahraničnými infiltrátormi. Vo Francúzku, nacionalistická politička Marine Le Penová uviedla, že Európa je napadnutá hordou „špinavých“ tmavých migrantov. Bývalý prezident Trump obhajoval svoje rozhodnutie obmedzit' prístup niekol'kým moslimským krajinám do USA vyjadrením, že „Islam nás nenávidí“ (Bergmann, 2018).

Antikrist. Teórie o existencii Antikrista sa zvyčajne odvíjajú okolo príbehov o satanistickej osobnosti, ktorá sa môže stat' vodcom svetovej diktatúry. V priebehu histórie bolo mnoho politických lídrov obvinených, že sú v skutočnosti Antikristi. Niektorí z nich z očividných dôvodov, ako fašistickí vodcovia Európy - Adolf Hitler a Benito Mussolini. Iní boli obvinení z menej zjavných dôvodov, v súčasnejšom období boli s identitou Antikrista spájaní napríklad bývalý americký prezident Barack Obama a bývalý pápež Ján Pavol II. Táto KT o Barackovi Obamovi motivovala Oscara Ortegu, aby sa v roku 2011 bývalého prezidenta pokúsil zavraždit' (Bergmann, 2018). 
Anti-Sorosovské KT. KT o finančníkovi Georgovi Sorosovi sú globálnym fenoménom prítomným v mnohých častiach sveta. Podoba týchto teórií sa mení v závislosti od lokálnych okolností. $V$ americkej spoločnosti napríklad rezonujú špekulácie, že Soros zamestnáva l'avicových protestantov či riadi politické a sociálne hnutia ako Black Lives Matter. Anti-sorosovské KT sú však rozšírené aj v štátoch strednej Európy. Hoci najskôr boli využívané najmä pravičiarskymi extrémistami a konšpiračnými médiami, neskôr sa stali nástrojom politických elít s populistickou rétorikou. Viktor Orbán, predseda mad'arskej politickej strany Fidesz, viedol intenzívnu kampaň proti Sorosovi už od roku 2017. Orbán obvinil Sorosa nielen z pokusov o zvrhnutie jeho vlády, ale aj z plánov zmenit' mad'arskú spoločnost' prostredníctvom migrácie a liberálnej agendy. Na Slovensku antisorosovské KT šíril predseda strany Smer-SD Robert Fico a to v roku 2018, kedy sa $v$ krajine organizovali masívne protivládne protesty. Fico za účelom diskreditácie týchto protestov rozširoval špekulácie o zahraničných silách, ktoré sa v spojení so Sorosom, opozíciou, médiami a zmanipulovanou mládežou snažia rozvrátit' fungovanie štátu (Plenta, 2020).

Covid-19 KT. Už vo februári 2020 Svetová zdravotnícka organizácia (WHO) vyhlásila, že svet musí zápasit́ nielen s následkami prebiehajúcej pandémie Covidu-19, ale aj s následkami "infodémie“, teda dezinformáciám a KT vzt́ahujúcim sa k vírusu (Zarocostas, 2020). Populistickí politici v podstate na celom svete prispeli $k$ „infodémii“ otvoreným nesúhlasom voči vedcom, voči iným politickým lídrom a voči celkovým prístupom k prebiehajúcej kríze (Evans \& Hargittai, 2020). Donald Trump napríklad v začiatkoch pandémie výrazne zl'ahčoval závažnost' šíriaceho sa vírusu a nemecká politická strana Alternatíva pre Nemecko v parlamente prezentovala názor, že vírus môže byt́ americká biologická zbraň (Eberl a kol., 2021). Masívne dezinformácie a KT zapríčinili globálne protesty proti súčasným vládam a opatreniam, ktoré určitá čast' spoločnosti nepovažovala za nevyhnutné. Okrem kritiky údajne antidemokratických preventívnych opatrení boli tieto protesty poháňané aj mnohými KT, napríklad že Covid-19 nie je horší ako chrípka a že je šírený $5 G$ rádiovými vinami (Ahmed a kol., 2020).

Využívanie KT na dosahovanie politických ciel'ov najmä populistickými politikmi je teda významná, súčasná a relevantná téma vkontexte globálnom, európskom, aj v kontexte slovenskom. 


\section{Rozdiely a podobnosti medzi populistickými postojmi a vierou v konšpiračné teórie}

Ako sme spomínali v predchádzajúcej kapitole, populistické postoje sa vyznačujú antielitárstvom a kritikou voči politike tých, ktorí sú pri moci (Vittori, 2017). Klúčovou charakteristikou populizmu je teda myšlienka lúuí proti elite, ako dvoch protikladných skupín, jedna vykreslená pozitívne, druhá negatívne. Populistickí politici často zdôrazňujú rozdelenie spoločnosti na bežných l'udí a elitu, pričom ich komunikácia je charakteristická preháňaním a podozrievaním (Gidron \& Bonikowski, 2013). Tento naratív je typický pre väčšinu KT. V podstate sa zhoduje so základným znakom KT, ktorým je (typicky zlá a zákerná) koalícia aktérov zahrňujúca mocné skupiny, ako sme ho opísali vyššie (van Prooijen \& van Vugt, 2018).

Už jednoduchým porovnaním tohto charakterizujúceho znaku je u oboch konštruktoch viditel'né podobné videnie reality. Populistické postoje aj viera v KT sa vyznačujú diskurzom, ktorý zdôrazňuje rozdelenie sveta na malú, elitnú, opresívnu a mocnú skupinu na vrchole spoločnosti a zranitel'né masy na jej spodku. Napriek tomu medzi fenoménmi v tomto ohlade zostáva pár podstatných rozdielov. KT nevyhnutne neveria $v$ "svätost" a „správnost" bežných ludí alebo že politickým ideálom je rozhodovanie verejnosti. Aj ked' je verejnost' v rámci KT vnímaná ako obet' elít, nepredpokladá sa jej morálna superiorita. Naopak, konšpirátori často vnímajú vlastnú superioritu voči verejnosti, pretože vich vnímaní sú inteligentnejší ako ostatní a vidia „pravdu“. Navyše, populistické postoje môžu niest' konšpiračné charakteristiky, nemusia však obsahovat' žiadnu konkrétnu KT. To môže byt' jedným z dôvodov, prečo sú populistické postoje globálne rozšírenejšie ako viera v KT (Silva a kol., 2017).

Ďalšou podstatnou podobnostou medzi populistickými postojmi a vierou v KT je zdôrazňovaná nedôvera v ustanovené, všeobecne platné poznatky, pravdy a v uznávaných odborníkov. Šíritelia populizmu často obviňujú média z neobjektívnosti a zaujatosti (obyčajne voči nim) a môžu ich stavat́ do pozície nepriatel'ov bežného l'udu (Fawzi, 2018). KT zase zvyčajne vnímajú prácu médií (a aj vedecké poznatky) ako účelové rozptyl'ovanie verejnosti a skrývanie skutočnej pravdy (Hameleers, 2021).

Na rozdiel od zložitých a komplikovaných informácií, ktoré sprostredkujú odborníci či vedecké výskumy, populizmus aj KT ponúkajú jednoduché riešenia na komplexné problémy. Kým populizmus nabáda k rozhodovaniu 
verejnosti, ktorá sa nemôže mýlit' (prostredníctvom svojich populistických politických reprezentantov) a jednoduchému zvrhnutiu elít, KT riešia komplikovanú siet' udalostí jedinou masívnou konšpiráciou (Bergmann, 2018).

Výskum desat'ročia odhal'uje, aké dispozičné vlastnosti súvisia s vyššou tendenciou verit' KT. Ako relevantné faktory predikujúce mieru viery v KT boli identifikované napríklad autoritárstvo (Abalakina-Paap a kol., 1999), pocity bezmocnosti, nízka interpersonálna dôvera (Goertzel, 1994), neistota (Van Prooijen \& Jostmann, 2013), tendencia verit' paranormálnym a nadprirodzeným javom (Bruder a kol., 2013) a preferencia pre manichejské vnímanie, teda zjednodušený náhlad na usporiadanie spoločnosti, v ktorej existujú len priatelia a nepriatelia (Oliver \& Wood, 2014). Niektoré z týchto faktorov (najmä posledný) sú typické tiež pre populistické postoje (Hawkins, 2010), čo môžeme považovat' za výraznú podobnost' medzi diskutovanými konštruktmi.

Populistické postoje a viera $v \mathrm{KT}$ prosperujú v podstate $v$ rovnakom prostredí. KT sa najviac šíria v prostredí, kde dominuje predsvedčenie, že všetci politici klamú a plánujú prevziat' kontrolu nad zbytkom spoločnosti. Rovnaké cynické videnie politických inštitúcií naplnené sklamaním a nespokojnostou je tiež asociované spreferenciami populistických politických strán (Doyle, 2011).

Autorka Golec de Zavala (2020) argumentuje, že tieto koncepty taktiež spája takzvaný kolektívny narcizmus, presvedčenie o výnimočnom postavení vlastnej skupiny (najčastejšie národa) a odpor z nedostatku ocenenia vlastnej skupiny. Jednotlivci skolektívnym narcizmom sú motivovaní hladat' vysvetlenia a dôvody, prečo ich skupina nie je dostatočne ocenená. KT či populistická rétorika môžu tieto vysvetlenia poskytnút - vinníkmi môžu byt' napríklad tajné zahraničné sily či zapredané, skorumpované elity, ktoré sa snažia potlačit' a zmenšit výnimočnost' danej skupiny či národa.

Zaujímavou spojitostou medzi populizmom a KT je aj negatívny, pejoratívny náboj týchto termínov. KT pritom nemusia byt automaticky vnímané ako negatívne a klamlivé, niektoré sa $v$ histórii potvrdili ako pravdivé - napríklad, že stavebné spoločnosti desiatky rokov zatajovali škodlivé účinky azbestu na l'udské zdravie. Populizmus bol zas v niektorých častiach sveta oslovovaný ako lídrami, tak aj verejnostou. Napriek tomu, ani populizmus, ani KT nie sú v politickom diskurze západného sveta 
neutrálnymi termínmi. Naopak, nesú v sebe negatívny význam podobný termínom extrémizmus či terorizmus. Populistickí politici sami seba nenazývajú „populistami“ a l'udia šíriaci alebo veriaci v KT sami seba neoznačujú ako „konšpirátorov“. Je skôr bežné, že tieto označenia sa používajú na diskreditáciu a zosmiešnenie politických oponentov (Bergmann, 2018).

Aj ked' sú populizmus a KT samostatné a pomerne jasne rozlíšitel'né koncepty, je nepochybné, že nesú mnoho spoločných znakov a vistom zmysle sa dopÍňajú. Štúdie opakovane ukazujú, že viera v KT významne koreluje so zranitel'nost'ou voči populistickej rétorike. Tí, ktorí sa cítia znevýhodnení a využívaní, sú omnoho viac náchylní verit' v KT a zároveň podporovat' populistické politické strany (Oliver \& Rahn, 2016). Možným vysvetlením je, že oba tieto prúdy podporujú nedôveru ako v elitu, tak aj v odborníkov.

\section{Ako populistickí politici využívajú konšpiračné teórie na manipuláciu verejnosti}

Populizmus je často charakterizovaný nepravdivým, realitu skresl'ujúcim diskurzom. Tento nepravdivý diskurz populizmus využíva troma podstatnými spôsobmi. Po prvé, často sa odkazuje na KT alebo celkovo pred očami verejnosti „ukrytú pravdu“. Po druhé, spochybňuje a zamieta expertné vedomosti, pravdivost' empirických informácií a legitímnost́ žurnalizmu a médií hlavného prúdu. Po tretie, predstavuje alternatívne pravdy, ktoré lepšie rezonujú sjednoduchším vnímaním sveta a skúsenost'ou bežných lúdí (Hameleers, 2020). Útočením na dokázané fakty a empirické dôkazy, faktická realita sa stáva zranitel'nou voči manipulácii a fabrikáciám (Monot, 2017).

Populistickí politici teda nepripisujú vinu za zlyhanie reprezentácie vôle bežného ludu len údajne skorumpovanej elite, ale často tiež poukazujú na skrytú realitu, konšpiráciu alebo skupinu aktérov, ktorí spoločne pracujú proti l'udu (Bergmann, 2018). Zaujímavé pritom je, že tento prístup je využitel'ný ako v opozičnej, tak aj v koaličnej politike. Ked' sú populisti v opozícii, ekonomické a politické elity sú vykresl'ované ako bábky v rukách korporácií. Ked’ sú populisti v koalícií, s korporáciami sú naopak spájaní opoziční politici, ktorí tajne plánujú ilegálne zvrhnutie populárnej a spravodlivej vlády (Silva a kol., 2017). 
A hoci je popisovaný diskurz typický skôr pre populistov krajnej pravice, vyskytuje sa aj u l'avicovo orientovaných politikov. Pravicové populistické strany zvyčajne tvrdia, že elity vspojení s migrantami spolupracujú na „nahradení" pôvodnej populácie. Na l'avicovom krídle KT často obsahujú údajnú kolaboráciu medzi extrémne bohatými (bankami, horným 1 \%) a politickou elitou, ktorí spoločne prispievajú k prehlbovaniu ekonomickej priepasti medzi extrémne bohatými a extrémne chudobnými (Aalberg a kol., 2017). Je teda zrejmé, že populizmus a využívanie KT v politickom súboji nie je vyhradené pre politikov určitého krídla alebo pozície.

Populistickí politici stendenciami využívat' KT pritom nelimitujú obviňované elity len na politických oponentov alebo členov súčasnej vlády. Súčastou údajne skorumpovanej elity bývajú tiež média hlavného prúdu, ktoré sú často označované ako Fake News (teda ako zdroj falošných správ a informácií), korporácie, či skorumpované štátne inštitúcie, ktoré údajne kradnú a zneužívajú bežných čestných l'udí (myšlienka využívaná ako pravicovými, tak aj lavicovými politikmi). Obviňovaniu sa nevyhnú ani nadnárodne inštitúcie, európski politickí reprezentanti krajnej pravice napríklad kritizujú činnost' EÚ. Podl'a ich rétoriky EÚ zavádza verejnost' globálnymi klimatickými zmenami a poškodzuje ju imigrantskou politikou, pričom jej ciel'om je pripravit' bežných l'udí o ich majetok a národnú identitu (Hameleers, 2020).

V mnohých prípadoch populisti explicitne poukazujú na konšpiráciu medzi rozličnými "nepriatel'mi“ bežného l'udu, teda medzi svojimi oponentami (Silva a kol., 2017). Napríklad, populisti poukážu na tajnú kolaboráciu iných politických aktérov s bankami či korporáciami, pričom účelom tejto spolupráce je presunutie finančných zdrojov verejnosti do ich vlastníctva. Takýto flexibilný prístup nájdenia „,vonkajšieho nepriatel'a“ v každej situácii vysvetl'uje, prečo populisti môžu zostat́ populistami aj ked' ich zvolia do pozície moci. Aj ked'sa sami stali súčastou štátneho politického systému, stále sú schopní zmiast' svojich voličov presunutím obvinení na iné elity. Známym príkladom je bývalý americký prezident Donald Trump, ktorého terčom boli pred zvolením demokratická strana a politické elity vo vláde. Po zvolení však presunul svoju pozornost' na takzvané Fake News, teda média hlavného prúdu šíriace nepravdivé informácie, ktoré ho údajne poškodzovali. Rétorika bývalého prezidenta sa rokmi čoraz viac opierala o KT. Táto zmena však postupne prebehla globálne, u mnohých politikov, známych aj menej známych. Vytvorenie konšpirácie, ktorá zahŕňa rôzne 
elitné skupiny obviňované z ohrozovania verejnosti, sa stali vel'mi efektívnou a flexibilnou komunikačnou taktikou, ako získat' politickú moc (Hameleers a kol., 2018).

\section{Politika dezinformácií}

Konšpirácie a populizmus sa stávajú v politike novým štandardom, pričom rozdiely medzi populistom a konšpirátorom sú stále menej zjavné. V kombinácii so skutočnost'ou, že čoraz väčšia čast' spoločnosti sa vyznačuje konšpiračnými myslením, je tento trend naozaj alarmujúci. Aktuálne prieskumy (Globsec, 2018; Klingová, 2019) ukazujú, že Slovenská republika sa spomedzi krajín strednej Európy vyznačuje najväčšou tendenciou verit' KT, nasledovaná Mad'arskom. 53 \% slovenských respondentov a $38 \%$ mad'arských respondentov uviedlo, že veria, že tajné skupiny ovládajú svetové udalosti za účelom zavedenia totalistického svetového systému. Americko-kanadský prieskum (Leibovitz a kol., 2021) zas preukázal, že v čase Covid-19 pandémie 49,7 \% respondentov verilo aspoň jednej KT.

Popieranie relevantnosti médií hlavného prúdu a vedeckých faktov podporované populistickými politikmi a konšpirátormi vedie $\mathrm{k}$ politike dezinformácií. Dezinformácia môže byt definovaná ako úmyselné šírenie nepravdivých a neúplných informácií (Freelon \& Wells, 2020) a môže byt' využívaná $k$ dosiahnutiu volebného úspechu alebo $k$ diskreditácii oponentov. Dezinformácie boli typicky spájané najmä s politickým štýlom krajnej pravice, ktorá môže šírit klamlivé informácie na zvýraznenie polarizácie a rozdielov $v$ spoločnosti a tým podporovat' nedôveru a cynizmus voči stanovenému politickému systému (Marwick \& Lewis, 2017). Je však potrebné poznamenat', že tieto stratégie už nie sú typické len pre krajnú pravicu, kedže sú v súčasnosti využívané politikmi všetkých orientácií a pozícií. Vytváranie dezinformácií sa týka mnohých svetových tém, niektorými z nich sú Európska migračná kríza z roku 2015, pandémia koronavírusu z roku 2020 či globálna klimatická zmena.

Populistické konštruovanie reality podporované dezinformáciami môže priniest' vážne politické a spoločenské dôsledky. Po prvé, ked' klamlivé obvinenia a KT rezonujú s populistickým nastavením verejnosti, vzniká množstvo skresleného vnímania faktov a informácií. Neinformovaní alebo zle informovaní voliči môžu byt pre fungovanie spoločnosti a demokracie vel'mi nebezpeční, ked'že takýto voliči nezakladajú svoje politické rozhodnutia na faktických informáciách. Namiesto toho sa spoliehajú na emócie (častokrát hnev a pocit bezradnosti), ktoré môžu byt' lahko 
manipulované a zneužité politickými aktérmi. Po druhé, podpora KT a dezinformácií rozdeluje spoločnost' a vytvára znepriatelené, polarizované skupiny. Čast' spoločnosti inklinujúca $k$ populistickým postojom a vierou v KT sa v tomto prípade separuje od časti spoločnosti, ktorá dôveruje expertným znalostiam a empirickým dôkazom. Príkladom môže byt zväčšujúca sa priepast' medzi pravicovými populistami a l'avicou v krajinách západnej Európy, ktoré boli historicky relatívne menej polarizované. Nakoniec, spochybňovanie médií hlavného prúdu a predstavenie alternatívnych dezinformačných médií vyvoláva v spoločnosti množstvo zmätku a skepticizmu. Vel'ká čast' verejnosti odrazu nie je schopná odlišovat' fakty od skreslených a zmanipulovaných informácií (Hameleers, 2020). Tento dôsledok je ešte viac akcentovaný $v$ dnešnej dobe neustále vyvíjajúcej technológie. Príkladom môže byt' technológia Deep Fake, pomocou ktorej je možné vytvárat' klamlivé audiovizuálne materiály, ktoré však pôsobia realisticky a autenticky. Takýto nástroj len rozširuje možnosti, ako jednoducho a efektívne šírit konšpirácie, dezinformácie či populistickú agendu (Whyte, 2020).

Politika dezinformácií pritom môže prispiet' $k$ skutočným l'udským tragédiám. Spomínaný Anders Breivik veril v KT s názvom Eurabia, bol teda presvedčený, že moslimovia v spolupráci s domácimi európskymi elitami plánujú premenit' Európu v islamskú spoločnost'. Breivik bol zradikalizovaný prostredníctvom online komunít, ktorých členovia aktívne šírili nebezpečné a násilie podporujúce dezinformácie. Podobnou ideológiou disponoval aj Thomas Mair, ktorý v roku 2016 zavraždil britskú poslankyňu Jo Cox. Timothy McVeigh zas spáchal bombový útok na budovu v Oklahoma City $v$ roku 1995, pri ktorom zomrelo 168 l'udí. Bol motivovaný presvedčením, že vláda USA má vúmysle zaviest' autoritatívnu diktatúru (Bergmann, 2018). Hoci tieto teroristické útoky nie je možné pripísat výlučne populistickému diskurzu či KT, sú dobrým reprezentantom toho, čo môžu dezinformácie spôsobit' v kombinácii s nestabilným prijímatel'om.

\section{Populistické postoje a konšpiračné teórie $\mathrm{v}$ časoch pandémie}

Ako už bolo spomenuté, pandémia Covidu-19 so sebou okrem šírenia vírusu priniesla aj šírenie mnohých KT - napríklad, že koronavírus Covid-19 nie je nebezpečnejší ako chrípka a že je šírený $5 \mathrm{G}$ rádiovými vlnami (Ahmed a kol., 2020). Pandémia však nepriniesla len samotné $K T$, ale aj nárast vo viere $v$ špecifické $K T$ a celkové rozšírenie konšpiračného myslenia. Autori Leibovitz a kol. (2021) zistili, že takmer polovica americko-kanadských 
respondentov $v$ ich štúdii $v$ začiatkoch pandémie verili aspoň $v$ jednu KT. Chorvátsky výskum preukázal, že 58,6 \% respondentov verilo, že „pravé štatistiky ludí infikovaných koronavírusom sú skryté pred verejnostou“, $45,1 \%$ respondentov verilo, že „koronavírus nepochádza zo zvierat a bol vytvorený vedcami vlaboratóriu“ a 38,7 \% respondentov bolo presvedčených, že „koronavírus bol rozšírený do sveta, aby zničil niektoré svetové ekonomiky“ (Tonković a kol., 2021). Americký výskum tiež zistil, že 29 \% skúmanej vzorky si myslelo, že „hrozba koronavírusu Covid-19 bola zveličená, aby poškodila prezidenta Donalda Trumpa" (Uscinski a kol., 2020).

Tieto a d'alšie KT boli v časoch pandémie šírené dezinformačnými médiami, populistickými politikmi či samozvanými, alternatívnymi expertmi. Prečo však vo verejnosti našli tak širokú podporu? Jedným z vysvetlení je, že populistické postoje vo forme spochybňovania elít a autorít (vrátane tých vedeckých) sú rozšírenejšie v časoch, ked' vedecké poznatky tvoria základ pre politické rozhodnutia (ako vobdobí pandémie), avšak tieto rozhodnutia sú charakterizované neistotou, nepredvídatel'nostou a je ich náročne dodržiavat' (Eberl a kol., 2021; Funtowicz \& Ravetz, 1993).

Povaha politickej odpovede na globálnu pandémiu vytvorila v podstate ideálne podmienky pre populistov, aby oponovali opatreniam a pre verejnost', aby verila konšpiráciám zameraným proti elitám. S prihliadnutím na značnú neistotu a značné tlaky konat', množstvo politík reagujúcich na šírenie vírusu bolo implementovaných vládami krízovo a okamžite, bez väčších debát v parlamentoch. $V$ spojení s väčšou mediálnou viditel'nostou epidemiológov, virológov a iných vedeckých odborníkov (Wormer, 2020) bolo jednoduché pre populistov a konšpirátorov tvrdit', že náhle a prísne vládne opatrenia sú výsledkom tajných dohôd medzi mocnými elitami (politikmi, vedcami, farmakologickým priemyslom či slávnymi filantropmi).

Výskum ukazuje, že vieru v KT o Covide-19 najsilnejšie predpovedali dôvera (respektíve nedôvera) vo vedu a vedcov a pocit politickej bezmocnosti. Autori teda podotýkajú, že obnovenie dôvery vo vedcov a vedecké inštitúcie a zredukovanie pocitu politickej bezmocnosti by mohlo napomôct́ $v$ boji proti potencionálne škodlivým presvedčeniam o pandémii (Tonković a kol., 2021).

Výskum odhalil aj d'alšie psychologické predispozície dôležité vo viere v Covid-19 KT - tendenciu popierat' odborné, autoritatívne informácie a tendenciu vnímat' sociálne a politické udalosti ako produkty konšpirácií 
(konšpiračné myslenie). Ked'že tieto tendencie tvoria podstatu hlbokej nedôvery v akúkolvek autoritu a odbornost', iní autori zastávajú názor, že korekcia dezinformácií a konšpiračných presvedčení je u tejto časti verejnosti pravdepodobne vel'mi náročná. U konšpirátorov a „popieračov“ je jednoducho nepravdepodobné, že zmenia svoje postoje na základe správnych informácií pochádzajúcich od odborníkov. Toto spojenie je potenciálnym dôvodom, prečo sú stratégie zamerané na korekciu týchto presvedčení prevažne neúspešné (Carey a kol., 2020; Uscinski a kol., 2020).

\section{Zhrnutie}

Súvislosti medzi populistickými postojmi a konšpiračným myslením sú $v$ dnešných časoch zjavnejšie ako $v$ minulosti. Výskum ukazuje, že tieto dva konštrukty sa často vyskytujú spoločne a vmnohom sa dopíňajú. Najvýraznejším aspektom spájajúcim túto dvojicu konštruktov je existencia elitnej, skorumpovanej (a v prípade konšpirátorov) tajnej vrstvy spoločnosti, ktorá nejakým spôsobom ohrozuje ostatných, bežných ludí. Populisti a konšpirátori však využívajú myšlienku elitnej skorumpovanej vrstvy spoločnosti vo svoj prospech podstatne odlišných spôsobom. Kým populisti sa snažia zmobilizovat' vrstvu bežných l'udí (teda verejnost') a pomocou nej dosahovat' politické úspechy, konšpirátori vo svojej podstate verejnostou pohŕdajú pre jej nevedomost' a pokúšajú sa vytvorit' inú elitnú skupinu, ktorá ako jediná pozná „skutočnú pravdu“. Takto sa tieto koncepty dajú porovnat' v ich tradičnom chápaní (Silva a kol., 2017). Alarmujúci je však fakt, že skupina, ktorá ako jediná pozná „skutočnú pravdu“, teda skupina l'udí stendenciou konšpiračného myslenia a verejnost' sa začínajú vo významnej miere prekrývat. Prieskumy konšpiračných presvedčení v priebehu pandémie ukazujú, že približne 30 až 50 \% verejnosti istej forme konšpirácií skutočne podlieha (Tonković a kol., 2021; Uscinski a kol., 2020). Je teda prirodzené, že s verejnost́ou osvojujúcou si konšpiračné myslenie, sa hranice medzi populistami a konšpirátormi budú postupne stierat', čo pre nás, ako pre spoločnost', rozhodne nie je lákavá predstava. Preto je dôležité nad'alej sledovat' vývoj týchto trendov, informovat' verejnost' o dôležitosti overených informácií a zdrojov a v najvyššej možnej miere zamedzit nepriaznivým dôsledkom týchto trendov na spoločnost'. 


\section{KAPITOLA}

\section{VÝVOJ MERACÍCH NÁSTROJOV POPULISTICKÝCH POSTOJOV}

Možnost' zist'ovat' a merat populizmus (na individuálnej úrovni) súvisí s jeho konceptualizáciou ako súboru postojov, ktoré majú jedinci voči politike a spoločnosti (napr. Akkermanová a kol., 2014; Hawkins a kol., 2012; Stanley, 2011). Vývoj meracích nástrojov týkajúcich sa populizmu sa udial najmä v poslednom desat́ročí. $V$ nasledujúcom texte tento vývoj popíšeme, pričom sa pokúsime poukázat' na teoretické vymedzenie konštruktu, z ktorého jednotliví autori vychádzali a na klúčové medzníky $v$ genéze vývoja (t. j. ako sa určité aspekty $v$ definovaní konštruktu prejavili v spôsobe jeho zistóvania a ako a/alebo prečo dochádzalo $k$ zmenám), resp. i širšie súvislosti validácie navrhovaných metodík. $V$ texte budú prezentované i konkrétne položky jednotlivých škál. Proces ich prekladu pozostával $v$ prvom kroku z troch nezávislých prekladov z pôvodného (angličtina) do ciel'ového (slovenčina) jazyka, pričom jeden z prekladatel'ov nebol informovaný o téme, resp. skúmanom koncepte. Následne boli preklady porovnané a diskrepancie diskutované. Na základe toho boli syntetizované konečné verzie, ktoré sú použité v texte tejto kapitoly.

Jednou z prvých empirických prác zameranou na zist'ovanie populistických postojov je práca Stanleyho (2011). Ním vypracovaná batéria otázok vychádzala z definície populizmu ako ideológie s obmedzeným definičným základom (thin-centered ideology), t. j. ideológie, ktorá je kombinovatel'ná s inými, viac etablovanými ideológiami, ako aj štyroch konceptov charakteristických pre rôzne prejavy populizmu. Boli to 1. existencia dvoch homogénnych jednotiek: skupiny l'udí a skupiny elity, 2. antagonistický vztáah medzi nimi, 3. idea suverenity l'udu (popular sovereignty) a napokon 4. pozitívne ocenenie, resp. chvála l'udí a očiernenie elity. Autorom naformulované položky (vychádzajúce z uvedeného teoretického vymedzenia) následne po dvojiciach korešpondovali sjednotlivými konceptmi (t. j. prvé dve položky sa týkali homogenity skupín l'udí a elity, d'alšie dve vnímania antagonistického charakteru politického života, tretia dvojica sa týka postojov k demokracii, a to konkrétne súhlasu s princípom väčšinovosti (majority) v populistickom koncepte demokracie a normatívneho želania po priamej verzus reprezentatívnej forme rozhodovania a napokon posledná dvojica sa týkala morálneho aspektu, ktorým je populizmus prítažlivý). Odpovede respondentov boli 
zaznamenávané prostredníctvom 7 bodovej škály, a to od absolútneho nesúhlasu (1) po absolútny súhlas (7). Naviac, položky boli formulované tak, aby i súhlas (dve otázky), ale i nesúhlas (šest' otázok) zachytával populistické postoje. Finálna batéria položiek mala nasledovnú podobu (originálne znenie položiek je uvedené v Prílohe 1):

\section{Batéria otázok týkajúcich sa populizmu podl'a Stanleyho (2011)}

1. Bežných l'udí delí mnoho rôznych hodnôt.*

2. L'udí, ktorí patria k politickej elite, delí mnoho rôznych hodnôt.*

3. Bežným l'ud'om činy nezodpovedných elít bránia v zlepšovaní ich života.

4. Nie všetci politici sú rovnakí, niektorým skutočne záleží na tom, čo l'udia chcú. *

5. Demokracia je o hladaní kompromisov medzi rôznymi záujmami a názormi.*

6. Bežní l'udia nie sú schopní uskutočnit' správne rozhodnutia týkajúce sa budúcnosti ich krajiny. ${ }^{*}$

7. Väčšina politikov sú čestní l'udia.*

8. Moderná politika je v podstate bojom medzi dobrými, čestnými l'ud'mi a zlou elitou.

Položky označené symbolom * je potrebné pri vyhodnotení prepólovat'.

Stanley (2011) následne nepracoval s celou škálou, t. j. hrubým skóre, resp. priemernou škálovou odpoved'ou, ale len s jednotlivými položkami, pričom preukázal, že iba položky 6 a 8 boli významnými prediktormi preferencie populistických politických blokov, resp. ich vol'by, a to konkrétne u slovenských respondentov (batéria bola súčastou Porovnávacej štúdie volebných systémov (Comparative Study of Electoral Systems(CSES)). Po zahrnutí socio-demografických, resp. iných postojových otázok, sa však i tie (t. j. 6. a 8. položka) stali nevýznamné, a teda sa nepreukázala súvislost́ populistických postojov (zistovaných navrhovanou metodikou) s príslušným volebným správaním. Vysvetlenie autorov spočívalo najmä v poukázaní na to, že populistické strany boli v tom čase súčast'ou vlády. Dôsledkom takejto situácie potom môže byt' to, že určití jedinci síce inklinujú k populizmu, no je pre nich náročné akceptovat' položky, že vládne elity sú homogénne a proti záujmom l'udí, ked'že tieto populistické politické strany, s ktorými oni sympatizujú, sú aktuálne vládnucou elitou. $Z$ toho dôvodu nemusela predložená metodika populistické postoje adekvátne zachytit'. 
Na americkom kontinente vytvorili jednu z prvých populistických škál Hawkins a kol. (2012). Populizmus bol uvedenými autormi definovaný ako súbor ideí/myšlienok, pričom následne poukázali najmä na jeho tri znaky, resp. charakteristiky:

1. Populizmus je chápaný ako súbor myšlienok zahŕňajúcich manichejský prístup k politickému svetu, ktorý stotožňuje stranu dobra s domnelou vôl'ou l'udí a stranu zla s konšpirujúcou elitou (conspiring elite) (Hawkins, 2010, in Hawkins a kol., 2012). Špecificky sa jedná o moralizujúce a dualistické presvedčenie o zvrchovanosti l'udí (t. j. vyzdvihuje sa názor väčšiny) a nemorálnej a zlomysel'nej opozícii, resp. tej druhej skupiny iných. Toto presvedčenie je v protiklade spluralizmom, prostredníctvom ktorého autori d'alej doplňujú vymedzenie populizmu. Ten zdôrazňuje nevyhnutnost' rôznorodosti názorov, kým populizmus požaduje morálnu jasnost' a vôl'u l'udí a námietka či nesúhlas (inakost') sú vnímané ako niečo, čo je podozrivé až nebezpečné. Populizmus teda vníma svet ako prirodzene antagonistický, pluralizmus vníma politické vzt́ahy cez optiku spolupráce.

2. Ďalším znakom je, že populizmus je špecifický a konkrétny druh myšlienok, resp. diskurz alebo ideológia s obmedzeným definičným základom (podobne ako pluralizmus), to znamená, že predstavuje len základný súbor predpokladov, týkajúcich sa politického sveta, ktorý má obmedzenú uplatnitel'nost' (Freeden 1996 in Hawkins a kol., 2012) a môže byt' spojený s množstvom iných ideológií.

3. Posledným znakom je, že hoci by populizmus nemal byt́ redukovaný na typ alebo črtu osobnosti, je podl'a autorov pravdepodobne ovplyvnený základnými črtami osobnosti, akými sú napríklad autoritárstvo (Adorno a kol., 1950 in Hawkins a kol., 2012) alebo otvorenost' voči skúsenosti (Monday a kol., 2010 in Hawkins a kol., 2012). A podobne ako môžu byt́ črty osobnosti neaktívne, kým nie sú aktivované kontextom, i vyjadrenie populistických postojov závisí podla autorov od toho, či sa občania konfrontujú s prostredím, ktoré vyvoláva populistickú reakciu a robí ju zmysluplnou alebo nie (Hawkins 2010, in Hawkins a kol., 2012).

Populizmus bol teda podobne ako v predchádzajúcom prípade vnímaný autormi ako súbor myšlienok, resp. ideológia s obmedzeným definičným základom a rovnako bolo zdôraznené manichejské vnímanie politiky (ako jeden z jeho podstatných znakov). Novými prvkami však boli teoretické 
vymedzenie populizmu voči iným konceptom (pluralizmu, ale i tzv. skrytej demokracii (stealth democracy)) a poukázanie na dôležitost' situačného kontextu, ktorý má potenciál aktivovat' jedincovo inklinovanie k populizmu.

Na základe tohto vymedzenia skonštruovali autori štvorpoložkovú batériu zachytávajúcu klúčové prvky populizmu, a to najmä manichejský pohl'ad na politiku, zámer (opätovného) uznania vôle l'udí a presvedčenie o konšpirujúcej elite. Jednotlivé položky boli nasledovné (ich originálne znenie je uvedené v Prílohe 2):

\section{Položky zistúujúce populistickú afinitu podl'a Hawkinsa a kol. (2012)}

1. Politika je v konečnom dôsledku bojom medzi dobrom a zlom.

2. Politici v Kongrese sa majú riadit' vôlou l'udí.

3. Moc pár špeciálnych záujmových skupín bráni našej krajine dosiahnut' pokrok.

4. Najdôležitejšie politické rozhodnutia by mali robit' l'udia, nie politici.

Odpovede respondentov boli vyjadrené na 4, resp. 5 bodovej škále (pozn. metodika bola overovaná v dvoch výskumoch, $v$ rámci ktorých bol rozdiel v použití 4 vs. 5 bodovej stupnice) vyjadrujúcej mieru súhlasu s týmito tvrdeniami ( $1=$ silne/rozhodne nesúhlasím, $4 / 5=$ silne/rozhodne súhlasím).

Preskúmaním metodiky $v$ dvoch reprezentatívnych výskumoch - prvým online v rámci celých Spojených štátov (the Cooperative Congressional Election Survey (CCES)) a druhým tvárou $v$ tvár (face to face) v konzervatívnom štáte Utah (the Utah Collages Exit Poll/UCEP) autori zistili, že súhlas respondentov s jednotlivými položkami (najmä poslednými tromi) je pomerne vysoký a podobný ako na vzorke $v$ Utahu, tak i v celých Spojených štátoch. Prostredníctvom faktorovej analýzy (s metódou principal factor estimations a orthogonal (varimax) rotáciou) d'alej preukázali, že jednotlivé položky skutočne tvorili samostatný faktor (s výnimkou prvej položky, ktorá sýtila príslušný faktor najslabšie -,37). Spol'ahlivost' škály však bola nízka (Cronbachova alfa = ,59 (UCEP), resp. , 65 (CCES). Ďalej tiež zistili, že súčastou populistického faktora boli i dve položky iného nástroja (t. j. skrytej demokracie (Hibbing \& Theiss-Morse, 2002, in Hawkins a kol., 2012), pričom ostatné dve položky tvorili faktor elitárstvo), ktoré navrhli zahrnút do finálnej metodiky, čo zvýšilo Cronbachovú alfu na akceptovatel'nú hodnotu ,73. Šlo o položky: 
5. Volení predstavitelia by krajine pomohli viac, keby prestali hovorit' a začali konat' $v$ súvislosti s dôležitými problémami.

6. To, čo l'udia $v$ politike nazývajú kompromisom, je $v$ skutočnosti len predávanie vlastných zásad.

Okrem preukázania, že príslušné položky skutočne sýtili rozdielne faktory populizmus a pluralizmus, zaujímavým zistením bolo, že položky populizmu (2. - 4.) v menšej miere sýtili i faktor pluralizmu (avšak položky sýtiace faktor pluralizmu sa v rámci faktora populizmu neprejavili), čo môže podl'a autorov znamenat' určité prekrývanie, resp. že niektorí pluralisti môžu sympatizovat' s populizmom, ale i to, že uvedené položky (najmä 2. - 4.) nediskriminujú populizmus adekvátne. Autori však konštatovali i to, že prvá položka pôvodne navrhovaného nástroja a druhá, doplnená položka (t. j. 1. a 6.) najzretel'nejšie zachytávali manichejský element populizmu (boli explicitne antipluralistické), kým ostatné položky sa týkali skôr demokratického aspektu populizmu (týkali sa inklinovania k vôli l'udu) a z toho dôvodu mohli mat' bližšie $k$ pluralizmu (t. j. s pluralizmom sa prelínali najmä tie položky populistickej škály, ktoré zdôrazňovali l'udovú suverenitu). Bez ohl'adu na to, prínosom výskumu bolo najmä preukázanie, že populizmus je skutočne koncept, ktorý je odlišitel'ný od iných politických ideológií (ako je elitárstvo či pluralizmus). Významným faktom je z nášho pohladu i prvotné hlbšie zamyslenie sa autorov nad existenciou skrytých (underlying) subdimenzií v rámci konceptu populistických postojov (uvedení autori reflektovali dve, a to l'udovú suverenitu a manichejský svetonázor, no pripúšt́ali i d’alšie) a nad potrebou ich preskúmania.

Na prácu Hawkinsa a kol. (2012) nadviazali Akkermanová a kol. (2014), ktorí pri prístupe k populizmu, resp. k populistickým postojom, zdôraznili nasledujúce potrebné a postačujúce podmienky. Populizmus je (obdobne ako $v$ predchádzajúcich prípadoch) ideológia $s$ obmedzeným definičným základom, podla ktorej je spoločnost' rozdelená na dve homogénne antagonistické časti, na skupinu poctivých l'udí a skorumpovanej elity a podl'a ktorej by politika mala byt' výrazom vôle ludí (the volonté générale) (Mudde, 2007, in Akkermanová a kol., 2014). Autori d'alej špecifikujú, že populisti definujú skupinu l'udí ako jadro a srdce demokracie. L'udia sú vnímaní nielen ako suverénni, ale aj ako homogénni, čistí či cnostní. Ĺudia sú následne v kontraste $s$ elitou, teda s tými, ktorí ohrozujú čistotu a jednotu suverénneho l'udu. Elita je vnímaná ako zlá, zatial' čo l'udia sú vnímaní ako dobrí. Toto rozlíšenie medzi dobrom a zlom alebo čistým a 
skorumpovaným je zásadným rozdielom a vymedzujúcim znakom populizmu. Napätie medzi l'ud'mi a elitou je manichejské, to znamená, že má v podstate morálnu kvalitu (Hawkins, 2009, in Akkermanová a kol., 2014).

Autori d'alej bližšie špecifikujú i pluralizmus a elitárstvo, ked'že ako sa ukázalo na predchádzajúcom výskume, je potrebné ich v súvislosti s populizmom vymedzit'. Uvádzajú, že populisti sú skeptickí voči jednému zo základných kameňov liberálnej demokracie - pluralizmu (Hawkins, 2009, in Akkermanová a kol., 2014; Mudde, 2007, in Akkermanová a kol., 2014). Konkrétne voči klúčovým znakom a inštitucionálnym štruktúram, ktoré sú vlastné pluralizmu, t. j. kompromisu, sprostredkovanému inštitucionálnymi orgánmi a procedúrami, ktoré zabezpečujú predovšetkým práva menšín. Elitárstvo predstavuje zrkadlový obraz populizmu (Mudde, 2004, in Akkermanová a kol., 2014), pričom zdiel'a s populizmom klúčový prvok manichejské rozdelenie spoločnosti na l'ud a elitu. $V$ kontraste $k$ populizmu však považuje elitu za čistú a cnostnú a l'ud za skorumpovaný. V praxi má však populizmus často nejednoznačný vztah k elitárstvu. Dôvodom môže byt́ i skutočnost', že napriek tomu, že populisti požadujú väčšiu (priamu) demokraciu, populistické hnutia často vedú charizmatickí lídri organizovaní vo vysoko centralizovaných a personalizovaných politických stranách. A hoci elitárstvo a charizmatické vedenie nie je to isté, často vyjadrujú podobný hierarchický koncept vedenia. Elitárstvo okrem toho zdiel'a $\mathrm{s}$ populizmom i (obvyklé) pohŕdanie politikou. Preto je možné, že aspoň v praxi sa populistické a elitárske myšlienky môžu do istej miery prekrývat', uzatvárajú autori.

Akkermanová a kol. (2014) pri konštruovaní svojej batérie zdôraznili, že výskum Hawkinsa a kol. (2012) bol dôležitým krokom pri vytváraní položiek merajúcich populizmus, pretože zahŕňal i jeho dva hlavné protiklady pluralizmus a elitárstvo a tento prístup zachovali i oni. Čo sa týka metodiky populizmu, okrem miernej modifikácie a prevzatia štyroch pôvodných položiek (t. j. 1., 2., 6. a 8. boli položky navrhnuté Hawkinsom a kol. (2012) v prvotnej verzii metodiky), do metodiky týkajúcej sa populizmu pridali i dve položky, ktoré Hawkins a kol. (2012) navrhovali doplnit' (t. j. 5. a 7.) a zároveň pridali i dve svoje položky (3. a 4.). Metodikou teda zachytávali tri hlavné znaky populizmu, ktoré ho definujú (vid' vyššie), a to l'udovú suverenitu, opozíciu l'udí voči elitám (resp. rozlíšenie medzi l'ud'mi a elitou) a manichejské rozlíšenie medzi dobrom (l'udom) a zlom (elitami) 
(Akkermanová a kol., 2014). Originálne znenie položiek je uvedené v Prílohe 3.

\section{Položky merajúce populizmus podl'a Akkermanovej a kol. (2014)}

1. Politici v holandskom parlamente by mali nasledovat' vôlu l'udí.

2. L'udia, nie politici, by mali robit' naše najdôležitejšie politické rozhodnutia.

3. Politické rozdiely medzi elitou a l'ud'mi sú väčšie ako rozdiely medzi l'ud'mi.

4. Radšej by som bol reprezentovaný občanom ako špecializovaným politikom.

5. Zvolení funkcionári príliš vela rozprávajú a málo konajú.

6. Politika je v konečnom dôsledku bojom medzi dobrom a zlom.*

7. To, čo ludia $v$ politike nazývajú kompromisom, je $v$ skutočnosti len predávanie vlastných zásad.

8. Záujmové skupiny majú príliš vel'ký vplyv na politické rozhodnutia.*

Položky označené symbolom * boli vylúčené $z$ finálnej verzie škály, z dôvodu sýtenia iného/iných faktorov.

Odpoved'ová likertová škála bola 5 bodová a variovala od silného nesúhlasu (1) po silný súhlas (5). Autori overovali metodiku u holandských respondentov, pričom na rozdiel od amerických kolegov, bolo cielom preskúmat i tzv. zdanlivú (face) validitu v súvislosti s volebným správaním, resp. podporou populistických politických strán. Ked'že holandský politický systém disponoval v tom čase ako pravicovo, tak i lavicovo orientovanými populistickými stranami, umožňoval podla autorov adekvátnejšie testovanie validity, pričom bol i viac inštitucionalizovaný, než to bolo v prípade (nepotvrdených) súvislostí medzi populistickými postojmi a podporou populistických politických strán u slovenských respondentov (Stanley, 2011).

Prostredníctvom faktorovej analýzy (s metódou principal component analysis a oblimin rotáciou) bolo zistené, že položky reprezentujúce populizmus, vskutku sýtili jeden faktor (s výnimkou dvoch pôvodných položiek, a to 6 . a nevyhranenej 8. položky, ktoré boli vylúčené z finálnej podoby metodiky). Autori $v$ súvislosti s navrhovanou metodikou konštatujú, že prvé štyri položky odzrkadlujú predstavy o typickej vláde, pričom vyjadrujú presvedčenie, že existuje rozdiel medzi l'ud'mi a politikmi (elitou) a že politici nereprezentujú skutočnú vôlu l'udí. Autormi pridaná 3. 
položka sa navyše zameriava na myšlienku, že l'udia majú medzi sebou navzájom viac spoločného ako s elitou. Manichejská dimenzia, teda napätie medzi dobrom a zlom, bolo zachytávané prostredníctvom 5., 6., a 7. položky, no 6. položka sýtila viac faktor elitárstvo. Toto zaujímavé zistenie je podl'a autorov možné vysvetlit' bud' tým, že táto položka nezachytáva aspekty dimenzie populizmu (ale skôr elitárstvo) alebo mohli mat' respondenti problémy $s$ jej interpretáciou. Táto položka bola pôvodne vytvorená pre latinskoamerické prostredie, kde populistickí lídri častejšie používajú nábožensky inšpirovaný diskurz, no v sekularizovaných krajinách ako je Holandsko, nemusí byt' k zist'ovaniu populizmu vhodná (vid' Hawkins, 2009, in Akkermanová a kol., 2014).

Autori tiež poukázali na to, že aj niektoré d’alšie položky populizmu (4. a 7.) do istej miery sýtili (okrem adekvátneho faktora i) faktor elitárstva, resp. položky elitárstva (1. a 3.) faktor populizmu či pluralizmu. Dôvodom môže byt' podl'a autorov fakt, že populizmus i elitárstvo sú voči politikom skeptické; v elitárstve sa to prejavuje v podpore úspešných podnikatel'ov a nezávislých odborníkov voči existujúcim politikom. $V$ prípade populistov sa to prejavuje $v$ prvom rade uprednostňovaním bežných občanov, ale aj $v$ podpore nezávislých odborníkov. Na druhej strane tiež nie je podla autorov žiadny teoretický dôvod, aby boli tieto škály (populizmu, elitárstva a pluralizmu) navzájom exkluzívne. Významné korelácie medzi populizmom a elitárstvom môžu napríklad poukazovat' na to, že l'udia môžu mat́ populistické postoje, ale stále uprednostňovat' profesionálneho (populistického) politika pred bežným občanom (alebo môžu byt populistickí, pretože sú nespokojní s vládnucou elitou), resp. významné korelácie medzi populizmom a pluralizmom môžu poukazovat' na to, že aspoň niektorí jedinci s populistickými postojmi akceptujú rôzne pohl'ady a podporujú potrebu kompromisov.

Záverom však treba zdôraznit', že napriek uvedeným nedostatkom, spol'ahlivost' škály populistických postojov tvorená šiestimi položkami bola vysoká (Cronbachová alfa mala hodnotu ,82). Zároveň autori potvrdili významnú a pozitívnu koreláciu medzi populistickými postojmi meranými uvedenou metodikou a zámerom volit' populistické politické strany, a to bez ohl'adu na ich pravicovú vs. l'avicovú orientáciu.

Ďalšími autormi v genéze vývoja nástroja na zistovanie populistických postojov boli Elchardus a Spruyt (2016) a ich výskum. Uvedení autori rovnako, ako tí pred nimi, vnímali populizmus ako ideológiu s obmedzeným 
definičným základom, pričom pri koncipovaní metodiky sa opierali predovšetkým o minimalistickú definíciu populizmu, zdôrazňujúcu tie prvky populizmu, ktoré sú vždy prítomné v diskurzívnych formuláciách populistickej ideológie a $v$ populistickej rétorike bez ohl'adu na kontext (napr. Mudde, 2004, in Elchardus \& Spruyt, 2016). Identifikovali dva také prvky, ktoré možno považovat' za jadro populizmu. Prvým je centralita a povýšený status l'udí alebo presnejšie bežných l'udí, pričom na označenie tejto skutočnosti bol použitý výraz centrizmus l'udí (people centrism). Druhá je vyjadrená na základe vertikálneho pohladu na sociálnu štruktúru, a to zradou bežných l'udí zo strany elity, ktorá využíva svoju moc vo svoj prospech a odmieta či ignoruje starosti a potreby týchto ludí (t. j. antisystémové stanovisko (anti-establishment stand)).

Navrhnutá metodika $\mathrm{k}$ zistóvaniu populistických postojov mala štyri položky. Kým 1. položka zdôrazňovala podl'a autorov normatívny aspekt, 2 . a 3. poukazovali skôr na to, že súčasní politici nie sú v kontakte s l'ud'mi a nechápu, čo sa deje medzi bežnými l'ud'mi. 4. položka (resp. i 2. v menšej miere), vyjadrovali, podl'a autorov, antielitársky postoj. Vzhl'adom k tomu, že viacerí autori považujú antielitárstvo (anti-elitism) za podstatný prvok či indikátor populizmu (napr. Mudde a kol., 2013, in Elchardus \& Spruyt, 2016), autori túto skutočnost' zahrnuli do svojej batérie. 4. položka odrážala podl'a autorov taktiež aktuálny záujem verejnosti o skutočnost', že vo všetkých formách politickej participácie dominujú vysoko vzdelaní jedinci, pričom antisystémový komponent bol $v$ kontexte tejto položky pridaný vd'aka diskurzu populistického flámskeho politika (podla ktorého súčasní politici získali mnoho diplomov, no nedostatočne navštevovali „univerzitu života“, a preto stratili kontakt s obyčajnými l'ud'mi a ich realitou). Originálne znenie položiek je uvedené v Prílohe 4.

\section{Populistická škála podl’a Elchardusa a Spruyta (2016)}

1. Názor bežných l'udí má väčšiu hodnotu ako názor odborníkov a politikov.

2. Politici by mali pozornejšie načúvat' problémom, ktoré majú l'udia.

3. Ministri by mali trávit menej času za stolom a viac medzi bežnými l'ud'mi.

4. L'udia, ktorí dlho študujú a majú vela diplomov v skutočnosti nevedia, čo sa deje vo svete okolo nich.

Odpoved'ová škála bola 5 bodová, pohybujúca sa od silného nesúhlasu (1) po silný súhlas (5) s jednotlivými tvrdeniami. 
Dôvodom prečo autori zvolili iný prístup ako Akkermanová a kol. (2014) či Hawkins a kol. (2012), t. j. že okrem centrizmu l'udí sa snažili zachytit' skôr jemnejšiu formu antisystémových nálad, bolo to, že 1. na jednej strane sa rôzni autori líšia $v$ tom, $v$ akej miere zdôrazňujú tento komponent $v$ rámci populizmu, 2. na strane druhej poukazujú na to, že Akkermanová a kol. (2014) zistili (na rozdiel od štúdií založených na dátach z USA (Hawkins a kol., 2012)), že silná formulácia týkajúca sa manichejského rozdelenia spoločnosti na dobro a zlo, nesýtila faktor populizmu.

$\mathrm{Na}$ vzorke flámskych respondentov (holandsky hovoriaci jedinci severnej časti Belgicka) preukázali, že skutočne viac respondentov (70 - $80 \%)$ súhlasilo s vyhláseniami, ktoré nabádajú politikov, aby sa viac prispôsobili problémom, ktoré vnímajú bežní l'udia a ich spôsobu myslenia (2. a 3. položka) a podstatne menej ( $40 \%$ ) súhlasilo s radikálnejšími tvrdeniami, že vysoko vzdelaní lúdia nevedia, ako veci skutočne fungujú a že názor obyčajných l'udí má väčšiu hodnotu ako názor odborníkov a politikov (1. a 4. položka). Spol'ahlivost́ škály bola dostatočná (Cronbachová alfa mala hodnotu, 78).

Uvedená škála populistických postojov bola následne dávaná do súvisu $\mathrm{s}$ rôznymi potenciálnymi prediktormi náchylnosti k populizmu, pričom zo zistení vyplynulo, že muži a jedinci s nižšou úrovňou vzdelania boli náchylnejší $k$ populizmu. Ďalšími zaujímavými a významnými determinantmi boli presvedčenia jedinca, že spoločnost' upadá (s vinou pripísanou politickým elitám) či pocity relatívnej deprivácie (t. j. nie nízka ekonomická pozícia, ale skôr interpretácia tejto zranitel'nosti, mala priamy efekt na populizmus) (Elchardus \& Spruyt, 2016). V závere autori zdôraznili, že iným prístupom chceli poukázat' najmä na to, že hranice populistického postoja (najmä $s$ ohladom na antisystémový komponent, resp. jeho extrémnejšiu formu), nie sú úplne pochopené a je preto rozumné sa zameriavat' skôr na iný komponent populizmu, napr. na centrizmus l'udí, resp. na umiernené a nie radikálne formy antisystémového komponentu (Elchardus \& Spruyt, 2016).

Medzníkom vo vývoji meracích nástrojov bolo presiahnutie operacionalizovania populizmu, resp. populistických postojov, ako jednodimenzionálneho konštruktu, ktoré do toho času vo výskumoch dominovalo. I ked' autori aj pred tým vnímali rôzne dimenzie $v$ rámci populistických postojov (vid' predchádzajúce škály), prvým explicitným operacionalizovaním populizmu prostredníctvom určitých dimenzií, bol 
výskum Schulzovej a kol. (2018). Autori, rovnako ako výskumníci pre nimi, vychádzali z perspektívy, ktorá definuje populizmus ako ideológiu $\mathrm{s}$ obmedzeným definičným základom (Mudde, 2004, in Schulzová a kol., 2018), no navrhli, aby boli populistické postoje konceptualizované ako latentný konštrukt vyššieho rádu s tromi subdimenziami. Ked'že podla populistickej ideológie má spoločnost' manichejskú štruktúru, pretože je $v$ konečnom dôsledku rozdelená na dve homogénne a antagonistické skupiny - morálne čistý l'ud (pure people) a skorumpovanú elitu a politika nie je nič iné ako vyjadrenie všeobecnej vôle l'udu (Mudde, 2004, in Schulzová a kol., 2018), je podl'a autorov možné z tejto definície akcentovat' tri politické myšlienky, ktoré spoločne populizmus vytvárajú/formujú. Ide o: 1. antielitársky prístup, v ktorom sú elity chápané ako skorumpované a klamúce l'udí; 2 . viera v l'udovú suverenitu, ktorá ponecháva moc l'ud'om a 3. chápanie l'udí ako homogénnych a čestných (virtuousness) (Wirth a kol., 2016, in Schulzová a kol., 2018). Autori teda koncipovali populizmus ako súbor politických myšlienok tvoriacich viacdimenzionálny konštrukt.

Pri pohl'ade na doterajšie skúmanie populistických postojov, autori poukázali na to, že napr. Akkermanová a kol. (2014) vypracovali jednodimenzionálnu koncepciu populistických postojov, no ich batéria obsahovala dve z troch kl'účových elementov populizmu (l'udovú suverenitu a antagonizmus voči tomu, čo je vnímané ako zlá politická elita).

Podl'a Schulzovej a kol. (2018) myšlienka, že l'udia sú homogénna skupina, ktorá je múdra a čestná, je rovnako nevyhnutná pre adekvátne definovanie populizmu (napr. Mudde, 2004, in Schulzová a kol., 2018). Opodstatnenost' svojho prístupu zdôraznili i poukázaním na to, že kvôli jednodimenzionálnosti nie je možné odhalit' rôzne (varietu) populistické postoje (Schulzová a kol., 2018).

Tvorba metodiky pozostávala z exploračnej (principle axis metóda s promax rotáciou) a následne konfirmačnej faktorovej analýzy (u druhej výskumnej vzorky) 21 iniciálnych položiek (devät' sa týkalo antielitárstva, šest' l'udovej suverenity a boli prevzaté z predchádzajúcich výskumov (Akkermanová a kol., 2014; Hawkins a kol., 2012; Hawkins \& Rovira Kaltwasser, 2014, in Schulzová a kol., 2018), d'alších šest' bolo vytvorených samotnými autormi za účelom uchopit presvedčenie o homogenite a čestnosti l'udí). Naprieč všetkými dimenziami bola zachytávaná i manichejská perspektíva populizmu prostredníctvom vyobrazenia entity l'udí proti entite politikov alebo vlády (Schulzová a kol., 2018). 
Metodika bola testovaná na švajčiarskych respondentoch a autori do svojho výskumu zahrnuli i elitárske postoje a postoje k pluralizmu, aby overili exkluzívnost' nimi koncipovaných populistických postojov (resp. jednotlivých položiek tvoriacich určité dimenzie) i voči týmto konštruktom. Finálna verzia metodiky mala 12 nasledujúcich položiek tvoriacich tri dimenzie (originálne znenie položiek je uvedené v Prílohe 5).

Dimenzie populistických postojov podl'a Schulzovej a kol. (2018)

\section{Komponent antielitárstvo}

1. Poslanci v parlamente vel'mi rýchlo strácajú kontakt s bežnými l'ud'mi.

2. Rozdiely medzi bežnými l'ud'mi a vládnucou elitou sú ovel'a väčšie ako rozdiely medzi bežnými l'ud'mi.

3. Ĺudia ako ja nemajú žiadny vplyv na to, čo robí vláda.

4. Politici príliš vel'a rozprávajú a málo konajú.

\section{Komponent l'udová suverenita}

5. L'udia by mali mat' posledné slovo v najdôležitejších politických otázkach tak, že o nich budú hlasovat' priamo v referende.

6. L'udia by mali byt́ oslovení vždy, ked' sa prijímajú dôležité rozhodnutia.

7. L'udia, nie politici, by mali robit' naše najdôležitejšie politické rozhodnutia.

8. Politici v parlamente by mali nasledovat vôlu l'udí.

\section{Komponent homogenita a čestnost' l'udí}

9. Bežní l'udia táahajú za jeden povraz.

10. Bežní l'udia majú dobrý a čestný charakter.

11.Bežní l'udia zdielajú rovnaké hodnoty a záujmy.

12. Hoci sa Švajčiari od seba vel'mi líšia, ked' príde na vec, všetci si myslia to isté.

Odpovede respondentov boli zistované prostredníctvom 5 bodovej odpoved'ovej likertovej škály variujúce od silného nesúhlasu (1) po silný súhlas (5).

Autori zistili, že dimenzia, na ktorú poukázali, resp. zdôraznili, t. j. homogenita a čestnost' ludí, bola najsilnejším (35\%), l'udová suverenita najslabším faktorom (8\%). Z predchádzajúcich štúdií Akkermanovej a kol. (2014), resp. Hawkinsa a kol. (2012) faktorovaním pretrvali štyri položky (t. j. 2., 4., 7. a 8.). Prínosom výskumu však bolo najmä to, že autori potvrdili, 
že populistické postoje sú latentný konštrukt vyššieho rádu, ktorý je tvorený tromi subdimenziami nižšieho rádu (trojfaktorový model mal lepšie ukazovatele model fit $v$ porovnaní s jednofaktorovovým, resp. i jednodimenzionálnou šest́položkovou škálou Akkermanovej a kol. (2014)). Autori taktiež potvrdili, že pluralizmus a elitárstvo boli odlišné faktory, ktoré negatívne korelovali so všetkými tromi subdimenziami populistických postojov.

$\mathrm{Na}$ trochu iné dimenzie populistických postojov poukázali svojim výskumom americkí autori Oliver a Rahnová (2016). V čase publikovania výskumu bolo pri moci v USA viacero populistických politikov, ako i prezident Donald Trump, ktorý sa tiež vyznačoval populistickou rétorikou. Je preto prirodzené, že vymedzili populizmus ako štýl politickej komunikácie, manichejského charakteru, ktorého ciel'om je taký politický poriadok, ktorý prinavráti ludí spät, na ich správne miesto (k vláde) a naviac, ktorý je plný obáv a podozrievavosti k tvrdeniam týkajúcim sa rôznych privilégií (pre určitú skupinu l'udí). Autori sa bližšie pozastavili najmä nad spôsobmi, ako populisti vymedzujú skupinu (bežných) ludí. Kým jedným zo spôsobov môže byt', že je to hockto, kto nie je elitou, časté je aj apelovanie na ekonomický a sociálny nacionalizmus (Jansen, 2011, in Oliver \& Rahnová, 2016). Konštrukcia my je podla autorov facilitovaná aj odvolávaním sa na „nepriatel'ov“ ludu (interných i externých), pretože ludia často prichádzajú na to, kto sú prostredníctvom toho, kto nie sú (Oliver \& Rahnová, 2016).

Vzhl'adom $\mathrm{k}$ tomu, že podstatným znakom populistickej politickej rétoriky je okrem iného i vytváranie unifikovanej skupiny ludí (napr. odkazovaním na národnost'/národ, krajinu, spomínanie zahraničných/cudzích krajín alebo hrozieb) predpokladali, že sa táto skutočnost' prejaví i ako dimenzia $\checkmark$ rámci populistických postojov.

Autori vytvorili batériu otázok (niektoré boli skonštruované samotnými autormi, iné prevzaté a adaptované z iných výskumov - Akkermanová a kol. (2014); Elchardus \& Spruyt (2016); Hawkins a kol. (2012); Spruyt a kol. (2016) in Oliver \& Rahnová (2016); Stanley (2011)), ktoré sa týkali politických procesov, vnímania odborníkov či bežnej múdrosti (common wisdom) ako aj vztahu (attachment) $\mathrm{k}$ americkej identite. Prostredníctvom faktorovej analýzy (s metódou principal component analysis) identifikovali 3 faktory, ktoré tvorilo 12 nasledujúcich položiek (ich originálne znenie je uvedené v Prílohe 6). 


\section{Dimenzie populistických postojov podl'a Olivera a Rahnovej (2016)}

Prvá dimenzia, antielitárstvo odrážala pocity marginalizácie týkajúce sa majetku a politickej moci, t. j. že malá skupina bohatej a mocnej elity drží všetky páky politickej moci.

1. L'udia ako ja nemajú čo povedat' k tomu, čo robí vláda.

2. V politike to vrie bojom medzi lud'mi a mocnými.

3. Systém je proti l'ud'om ako som ja.

4. Skutočne nezáleží na tom, koho volíte, pretože bohatí kontrolujú všetky ( $v$ prípade USA obe) politické strany.

5. Ĺudia sa na vrchol dostanú pretože majú viac talentu a tažko pracujú/zvyčajne nejakou neférovou výhodou (nečestne).

Druhá dimenzia, nedôvera voči odborníkom, indikovala skeptický pohlad na expertov a ich názory, ako aj vieru v bežnú múdrost', resp. presvedčenie, že vedomosti l'udí sú validnejšie než názory odborníkov.

6. Radšej by som dôveroval múdrosti bežných l'udí ako názorom odborníkov a intelektuálov.

7. Ak príde na skutočne dôležité otázky, vedecké fakty vel'mi nepomáhajú.

8. Bežní l'udia môžu skutočne využit' pomoc odborníkov na pochopenie zložitých vecí, akými sú veda a zdravie.

9. Politika je v končenom dôsledku bojom dobra a zla.

Tretia dimenzia, národná príslušnost' zachytávala príslušnost' respondenta, resp. jeho podobnost' k/s „americkým l'udom“, t. j. bola o kolektívnej americkej identite.

10. Bolo by nerozumné verit úsudkom amerického ludu $v$ súvislosti $s$ dnešnými komplikovanými politickými problémami/Všeobecne verím v kolektívne súdy amerického l'udu aj v prípade zložitých politických problémov.

11. Všeobecne sa považujem za iného ako väčšina Američanov/ako väčšina ostatných Američanov.

12. Ako dôležité je byt' Američanom pre to, kým ste?

Odpoved'ová škála pozostávala z rôznych kategórií, t. j. výberu z 2 možností (položky: 5., 11., 12.), 5 bodovej (položky: 1. -4., 6. -10.) a 7 bodovej (13. položka) stupnice indikujúcej rastúci súhlas, resp. dôležitost'. Jednu položku bolo potrebné prepólovat' (8.). 
Autori d’alej neskúmali psychometrické vlastnosti nástroja, skôr sa zameriavali na súvislosti jednotlivých dimenzií s inými premennými. Vzhladom $\mathrm{k}$ tomu, nie je vel'mi prekvapujúce, že jednotlivé dimenzie mali rozdielne súvislosti, a teda takto koncipované dimenzie populistických postojov takpovediac "netahali“ spolu (napr. antielitárstvo súviselo s inklinovaním ku konšpiračným teóriám či nedôverou iným, kým národná príslušnost́ súvisela s nedôverou iným negatívne, t. j. takíto l'udia sú skôr dôverčivejší).

Na d'alšie dimenzie poukázali Hoboltová a kol. (2016) v module dotazníka 5. viny Porovnávacej štúdie volebných systémov (Module of the wave 5 questionnaire of CSES, Hoboltová a kol., 2016) s názvom Populizmus, vnímanie elít, korupcie a postoje voči reprezentatívnej demokracii.

Autori taktiež vychádzali z Muddeho (2007, in Hoboltová a kol., 2016) definície. Následným zamyslením sa nad príčinami a dôsledkami populistických postojov sa priklonili k názoru, že napätie medzi bežnými občanmi a elitami súvisí s tým, že politické strany neplnia svoju úlohu. I ked' negatívne postoje $\mathrm{k}$ politickým elitám sa nemusia zhodovat' $\mathrm{s}$ populistickými postojmi, v srdci populizmu je viera, že politické elity a ludia majú kontrastné a nezlučitel'né záujmy. Populizmus tiež zahŕňa odmietanie pluralizmu a nesúhlas s ochranou menšín (Mudde \& Kaltwasser, 2012, in Hoboltová a kol., 2016). Toto odmietnutie politickej elity a konvenčných prvkov zastupitel'skej demokracie sa spája s rastúcim dopytom po (priamej) účasti občanov na rozhodovaní. Podl'a autorov sú teda jadrom populizmu chvála l'udí (praise of the people) a antielitárstvo.

Jadrom modulu bolo skúmanie populistických postojov prostredníctvom troch základných tém:

\section{Postoje k politickým elitám.}

\section{Postoje k zastupitel'skej demokracii a vláde väčšiny.}

\section{Postoje k l'ud'om mimo skupiny.}

Navrhnuté položky týchto tém CSES Modulu 5 (Hoboltová a kol., 2016) sú popísané nižšie (originálne znenie je uvedené v Prílohe 7). Odpoved'ová škála bola 5 bodová.

Otázky prvej témy (položky Q4 (b, c, d) a Q7) sa týkali rôznych aspektov negatívnych postojov kelite. Tou boli najmä politici, pričom autori poukazujú na jej homogénnost', no neopomínajú ani manichejský pohlad. 
Kedže l'avicoví populisti často zobrazujú elitu ako bohatých, ekonomicky zvýhodnených jedincov $v$ opozícii voči bežným, ekonomicky a sociálne znevýhodneným l'ud'om, bola i táto skutočnost' zahrnutá do modulu (Q4g). Q4 Súhlasíte, skôr súhlasíte, ani súhlasíte ani nesúhlasíte, skôr nesúhlasíte a rozhodne nesúhlasíte s nasledujúcimi vyhláseniami?

a. To, čo ludia $v$ politike nazývajú kompromisom, je $v$ skutočnosti len predávanie vlastných zásad.

b. Väčšina politikov sa o l'udí nezaujíma.

c. Väčšina politikov je dôveryhodná.*

d. Politici sú hlavným problémom (KRAJINY).

e. Mat' silného lídra vo vláde je pre (KRAJINU) dobré, aj ked' vodca ohýba pravidlá, aby mohol veci dokončit'.

f. Ĺudia, nie politici, by mali robit' naše najdôležitejšie politické rozhodnutia.

g. Väčšina politikov sa stará iba o záujmy bohatých a mocných.

Q7 Ako vel'mi je podla vás korupcia, ako napríklad prijímanie úplatkov medzi politikmi v (KRAJINA) rozšírená? vel'mi rozšírená, pomerne rozšírená, nie vel'mi rozšírená, takmer vôbec sa to nestane.

Otázky druhej témy sa týkali dvoch alternatív vysporiadania sa so „skorumpovaným“ reprezentatívnym systémom, a to prostredníctvom charizmatického vodcu a priamym zapojením l'udí do rozhodovania (Q4e a Q4f). Ked'že populizmus má tendenciu dávat' prednost' vláde väčšiny, práva menšín sú na vedl'ajšom mieste ( $Q 5 b)$. A vzhl'adom k tomu, že dôsledkom silného vedenia či vlády väčšiny je, že pluralistické procesy vyjednávania, resp. kompromisy (štandardne prítomné u vládnucich politických elít) sú zbytočné, je i táto skutočnost' súčast'ou otázok (Q4a).

Q5 Teraz uvažujte o menšinách. Súhlasíte, skôr súhlasíte, ani súhlasíte ani nesúhlasíte, skôr nesúhlasíte, rozhodne nesúhlasíte $s$ nasledujúcimi vyhláseniami?

a. Pre spoločnost' je lepšie, ak si menšiny zachovávajú svoje odlišné zvyky a tradície.

b. Vôl'a väčšiny by mala vždy prevládat aj nad právami menšín. 
Otázky tretej témy sú založené na predpoklade, že l'udia existujú, pričom sú homogénni a súdržní. Na podporu budovania komunity je $v$ mnohých situáciách klúčové vymedzenie vonkajších (tzv. out) skupín, ktoré sa môžu $v$ jednotlivých krajinách ( $v$ závislosti od národnej histórie a sociálnych štruktúr) líšit. Etnické menšiny a pristahovalci však patria medzi najviditel'nejšie skupiny, ktoré „nepatria“ k národu (zdôrazňované pravicovým populizmom) (Q5a, c, d, e). Chvála l'udí je primárnou charakteristikou každej definície populizmu, kto však patrí k l'udu, je faktorom rozlišujúcim rôzne druhy populizmu. Ten pravicový chápe l'ud spôsobom, ktorý má korene v nacionalizme a nativistickej definícii (t. j. na základe náboženstva, predkov, etnickej príslušnosti) (túto koncepciu zist'ujú Q6a až d).

Q5 A teraz uvažujte konkrétne o imigrantoch. Súhlasíte, skôr súhlasíte, ani súhlasíte ani nesúhlasíte, skôr nesúhlasíte, rozhodne nesúhlasíte $\mathrm{s}$ nasledujúcimi vyhláseniami?

c. Imigranti vo všeobecnosti sú pre ekonomiku (KRAJINY) prospešní.

d. Imigranti vo všeobecnosti poškodzujú kultúru (KRAJINY).

e. Imigranti zvyšujú kriminalitu.

Q6 Teraz zmena témy ...Ako dôležité sú podl'a vás nasledujúce skutočnosti, aby ste boli skutočne (NÁRODNOSŤ)... vel'mi dôležité, dost' dôležité, nie príliš dôležité alebo vôbec nie je dôležité?

a. Narodit' sa v (KRAJINA).

b. Mat' (NÁRODNOSŤ) predkov.

c. Vediet' hovorit' (NÁRODNÝMI JAZYKMI KRAJINY).

d. Dodržiavat' zvyky a tradície (KRAJINY).

Jednu položku (označenú symbolom *) je potrebné prepólovat'.

Hoboltová a kol. (2016) prostredníctvom CSES Modulu 5 predkladajú len jednotlivé položky metodiky a ich zdôvodnenie, konkrétne zistenia vyplývajúce z použitia tejto škály nie sú uvedené.

Vychádzajúc z uvedomenia si niektorých metodologických nedostatkov predchádzajúcich metodík (napr. limitujúca schopnost' položiek identifikovat' extrémne póly (nízke i vysoké) populizmu (Van Hauwaert a kol., 2018), alebo poukázanie na skutočnost', že ak sú všetky položky 
formulované pozitívne (t. j. čím silnejší súhlas, tým intenzívnejší koncept), je náročné diskriminovat', či sa jedná o intenzitu postoja alebo o tendenciu k súhlasnému stanovisku (acquiescence bias)), uskutočnili Castanho Silva a kol. (2018) rozsiahli výskum. Okrem vysporiadania sa s uvedenými nedostatkami dovtedajších meracích nástrojov, ich ciel'om bolo pomocou rôznych techník vybrat' z vel'kého počtu položiek nielen tie, ktoré najlepšie zachytávajú populistické postoje, ale zároveň sú $v$ rôznych krajinách nemenné (t. j. invariantné).

Vychádzali z rovnakej definície populizmu ako mnohí iní autori pred nimi (Mudde, 2004, in Castanho Silva a kol., 2018), následne z nej však odvodili, resp. dali dôraz na čiastočne iné tri prvky, než autori pred nimi. Nazvali ich základnými zložkami populistických postojov a jednalo sa o: 1 . predstavu dobrého, homogénneho l'udu ako politického aktéra; 2 . antielitárstvo a 3. pohl'ad na politiku ako na morálny boj, kde je jedna strana očividne dobrá a druhá zlá - tzv. manichejské vnímanie (Castanho Silva a kol., 2018). Na rozdiel od Schulzovej a kol. (2018) troch komponentov populistických postojov (t. j. antielitártsvo, ludová suverenita a homogenita \& čestnost' l'udí), (opätovne) zdôrazňujú manichejské vnímanie $v$ súvislosti $s$ populistickými postojmi. Ako autori d'alej pokračujú, politiku je možné vnímat' ako boj dobra a zla bez toho, aby boli tieto pozície obsadzované l'ud'mi a elitami. Ich zámerom bolo teda merat' manichejský prvok v jeho „čistej“ forme, resp. v takejto forme preskúmat́ a posúdit' jeho empirický vztáa s inými konštituujúcimi prvkami populizmu (Castanho Silva a kol., 2018). Vzhl'adom $k$ tomu, že všetky tri vyššie uvedené zložky sú nevyhnutnými súčastámi východiskovej definície, uvedení autori tiež navrhujú, aby populizmus existoval na priesečníku týchto širších druhov diskurzu. $Z$ toho vyplýva, že jeho meranie by malo zahŕňat' rôzne aspekty oddelene, čo sa len zriedka $v$ minulosti zohl'adnilo (výnimkou sú napr. Schulzová \& kol., 2018, Stanley, 2011, resp. Oliver \& Rahnová, 2016). Skôr prevládalo jednodimenzionálne koncipovanie, pričom sa eliminovali všetky nadbytočné položky (t. j. eliminovali sa všetky položky, ktoré nesýtili jeden hlavný faktor) (Castanho Silva a kol., 2018). Ak má však populizmus odlišné zložky, treba podl'a autorov počítat' s tým, že nie všetky položky sa budú správat' tak, ako keby merali jeden konštrukt.

Tvorba metodiky spočívala najskôr v identifikovaní základných: 1 . chvála l'udí, 2. antielitárske a antisystémové postoje a 3. manichejské vnímanie politiky, ale i potenciálnych (1. uprednostňovanie silného vodcu, 2. 
jednoduchý a priamy štýl, 3. vnímanie krízy a 4. postoje k „čokolvek je možné uskutočnit") zložiek populizmu. $\mathrm{Na}$ základe toho bolo naformulovaných 145 potenciálnych položiek.

V súvislosti so základnými zložkami doplníme, že pri identifikovaní prvej zložky vychádzali autori z názoru, že populistický diskurz nielen chváli l'udí a jeho hodnoty, ale tiež chápe, že: 1. l'udia sú homogénnou entitou, ktorá 2. má identifikovatel'nú všeobecnú vôlu (general will), ktorá by mala byt základom celej politiky (Mudde, 2004, in Castanho Silva a kol. 2018). V tejto zložke sú teda spojené dve dimenzie Schulzovej a kol. (2018) - t. j. suverenita ludu (sovereignty of people) a homogenita a čestnost' l'udí, do jednej.

Čo sa týka manichejského vnímania politiky (tretia zložka), to bolo podl'a autorov často súčastou antisystémových položiek (vid' napr. metodiku Akkermanovej a kol., 2014). Jedna položka, ktorá predstavovala tzv. „čistú“ formu manichejského vnímania politiky (t. j. Politika je $v$ konečnom dôsledku bojom medzi dobrom a zlom), nesýtila faktor jednodimenzionálneho populizmu (Akkermanová a kol., 2014). Kedže však bola len jedna, nebolo možné určit, či bola alebo nebola súčastou samostatnej latentnej dimenzie (Castanho Silva a kol., 2018). Autori sa preto pokúsili naformulovat i d'alšie otázky týkajúce sa toho, či respondent vníma politiku ako morálny boj bez toho, aby sa odvolávali na l'udí alebo elitu.

Následne boli prostredníctvom faktorovej analýzy (metódou exploračnej faktorovej analýzy s oblique rotáciou) identifikované tri faktory/dimenzie, a to: 1 . centrizmus l'udí, 2 . antielitárstvo a 3 . manichejské vnímanie politiky. Jednotlivé položky týchto dimenzií boli nasledovné (ich originálne znenie je uvedené v Prílohe 8 ). Odpoved’ová škála bola 7 bodová indikujúca rastúci súhlas respondenta.

\section{Škála populistických postojov (Castanho Silva a kol., 2018)}

\section{Centrizmus l'udí}

1. Politici by mali vždy pozorne počúvat' problémy l'udí.

2. Politici nemusia trávit' čas medzi bežnými l'ud'mi, aby odviedli dobrú prácu.*

3. Vôla l'udí by mala byt' najvyšším princípom politiky tejto krajiny. 


\section{Antielitárstvo}

4. Vládu do značnej miery riadi niekol'ko vysoko zainteresovaných strán, ktoré sa primárne starajú o seba.

5. Vládni predstavitelia využívajú svoju moc na zlepšovanie života l'udí.*

6. Pomerne vela l'udí vo vláde má pokrivený charakter.

\section{Manichejské vnímanie politiky}

7. Môžeme povedat', či je človek dobrý alebo zlý, ak poznáme jeho politické preferencie.

8. L'udia, s ktorými politicky nesúhlasím, nie sú zlí.*

9. L'udia, s ktorými politicky nesúhlasím, sú len dezinformovaní.

Položky označené symbolom * je potrebné pri vyhodnotení prepólovat'.

Významným prínosom výskumu bolo, že na rozdiel od všetkých doterajších metodík, autori (testovaním invariancie) potvrdili vysoký stupeň medzinárodnej (cross national) validity škály v medzinárodnom porovnaní (minimálne $v 13$ krajinách s pravicovým i lavicovým populizmom, kde výskum prebiehal), čo je dôležitým aspektom, ak niekto plánuje zahrnút batériu do výskumu populizmu v rôznych krajinách (Castanho Silva a kol., 2018). Autori tiež preukázali prostredníctvom teórie odpovede na položku (Item Response Theory - IRT), ktorá sa zaoberá vztáahom medzi odpoved’ami respondentov na konkrétny súbor položiek a základným latentným konštruktom, t. j. populistickými postojmi (Hambleton a kol., 1991, in Castanho Silva a kol., 2018)), že škála zachytávala i pomerne široký rozsah konštruktu.

Batériu je možné použit' $s$ deviatimi alebo len so šiestim položkami (t. j. bez položiek, ktoré je potrebné prepólovat'), avšak opačne, resp. negatívne naformulované položky $v$ každej $z$ dimenzií slúžia $k$ utvrdeniu, že sú skutočne merané populistické postoje a nie tendencia k súhlasu (Castanho Silva a kol., 2018), pretože i tá môže prispievat' k tomu, že populistické postoje sú pomerne rozšírené takmer všade, kde sa merajú (vid' napr. Elchardus \& Spruyt, 2016; Hawkins, a kol., 2012; Schulzová a kol., 2018).

Z teoretického hladiska je dôležité zdôraznit', že výskum Castanho Silvu a kol. (2018) potvrdil, že všeobecné manichejské vnímanie politiky je súčast'ou populistických postojov, čo nebolo do toho času testované, resp. manichejské vnímanie bolo iba zakomponované do toho, ako populizmus/populisti rámcovali elity a ludí. Ďalším zistením bolo, že nebolo 
možné štatisticky rozlíšit medzi chválou bežných l'udí a ideou l'udovej suverenity v politike. I ked' sú považované za koncepčne odlišné (napr. Mudde \& Rovira Kaltwasser, 2017, in Castanho Silva a kol., 2018), na úrovni postojov sú pravdepodobne príliš blízko na to, aby sa dali navzájom rozlí̌it' (Castanho Silva a kol., 2018).

Na záver ešte v krátkosti spomenieme výskum Van Hauwaerta a kol. (2020), ktorí síce nevychádzali zo špecifického koncipovania populizmu (ako doteraz spomínaní autori), no preukázali vel'mi dobré psychometrické vlastnosti modifikovaného nástroja. Základ tvorili položky škály od Hawkinsa a kol. (2012), ktoré Akkermanová a kol. (2014) rozšírili do šest́položkovej verzie.

Prostredníctvom IRT autori preskúmali nielen pôvodnú, ale idve modifikované verzie, pričom ciel'om bolo preukázat' validitu nástroja/ov (testovanie sa uskutočnilo na početnej výskumne vzorke ( $N=18$ 368) z deviatich európskych krajín). Podla autorov sa mnoho doterajších výskumov spoliehalo na nie celkom adekvátne metódy (napr. principal component analysis), resp. na metódy, ktoré poskytujú len obmedzené posúdenie charakteristík položiek nástroja. Ostáva nejasné, kol'ko a ktoré položky sú nevyhnutné k presnému a komplexnému meraniu populizmu. Zároveň mnohé sa sústred'ujú na meranie populizmu v konkrétnej krajine, čo otvára otázku o uplatnitel'nosti jednotlivých škál v nadnárodnom kontexte (Van Hauwaert a kol., 2020).

Autori vymedzili populizmus (obdobne ako mnohí pred nimi) na základe Muddeho (2004, in Van Hauwaert a kol., 2020) definície. Ďalej sa tiež priklonili k trojzložkovej koncepcii, podl'a ktorej je populizmus kombináciou antielitárstva, ludovej suverenity a manichejského svetonázoru. Populistické postoje sú následne súborom hodnotiacich reakcií na tieto prvky (Van Hauwaert a kol., 2020).

Autori testovali tri metodiky. Prvá pozostávala z pôvodných šest' položiek, ktoré používali vo svojom výskume Akkermanová a kol. (2014). Položky zachytávali vzdialenost́ medzi l'ud'mi a elitami (3. a 5. položka), inherentnú vieru v l'udovú suverenitu) (1., 2. a 4. položka) a manichejské vnímanie (6. položka). Druhá pozostávala z ôsmich položiek, t. j. k pôvodným položkám autori doplnili d'alšie dve scielom zachytit', ako jednotlivci vnímajú pretrvávajúci negatívny vplyv správania a záujmov elít na ich život, resp. vnímanie (politických) elít ako negatívnych a samoúčelných autorít (7. a 8. položka) (podla autorov presahujú tieto položky tie pôvodné antielitárske 
tým, že skúmajú jedincove vlastné vnímanie negatívneho a antagonistického vztahu medzi l'ud'mi a elitami). Tretia pozostávala z troch položiek, ktoré boli testovaním identifikované, ako najadekvátnejšie k zistóvaniu populizmu. (Originálne znenie položiek je uvedené v Prílohe 9).

Van Hauwaertova a kol. (2020) modifikovaná (8 položková) verzia Akkermanovej a kol. (2014) škály populistických postojov.

1. Politici v parlamente by mali nasledovat' vôlu l'udí. (l'udová suverenita)*

2. L'udia, nie politici, by mali robit' naše najdôležitejšie politické rozhodnutia. (l'udová suverenita)

3. Politické rozdiely medzi elitou a l'ud'mi sú väčšie ako rozdiely medzi l'ud'mi. (antielitárstvo)

4. Radšej by som bol reprezentovaný občanom ako špecializovaným politikom. (l'udová suverenita)

5. Zvolení funkcionári príliš vel'a rozprávajú a málo konajú. (antielitárstvo)

6. To, čo l'udia v politike nazývajú „kompromisom“, je v skutočnosti len predávanie vlastných zásad. (manichejské vnímanie)*

7. Osobitné záujmy politickej triedy negatívne ovplyvňujú blaho l'udí. (antielitárstvo, dopInená položka)*

8. Politici vždy súhlasia, pokial' ide o ochranu ich výsad. (antielitárstvo, doplnená položka)

Symbolom * sú označené položky skrátenej, trojpoložkovej verzie škály populistických postojov.

Odpovede respondentov boli zist'ované na 5 bodovej stupnici likertovho typu, variujúce od rozhodne nesúhlasím (1) po rozhodne súhlasím (5).

Prostredníctvom hlbšej položkovej analýzy (IRT) autori zistili, že pôvodný šest́položkový nástroj meria skôr nižšie a stredné úrovne populistických postojov. 5. položka bola najviac informatívna (t. j. umožňovala najpresnejšiu diskrimináciu jedincov naprieč úrovňami populistických postojov), 6. položka najmenej. Tento manichejský indikátor (t. j. 6. položka) teda vyžadoval k súhlasu najvyššiu populistickú úroveň jedinca, na druhej strane bola jedinou položkou, ktorá mala schopnost' diskriminovat' účastníkov na vyšších úrovniach populistických postojov.

V súvislosti s osempoložkovou modifikovanou verziou bol preukázaný nárast informačnej úrovne. Autormi pridané položky (7. a 8.), boli najinformatívnejšie (spolu s 5. položkou) populistickej škály. Napriek tomu, ani táto modifikovaná verzia nezachytávala celý rozsah populizmu. 
Autori preto navrhli škálu pozostávajúcu z troch položiek odrážajúcich l'udovú suverenitu (1. položka), manichejské vnímanie (6. položka) a antielitárstvo (7. položka). Položka týkajúca sa suverenity ludu najlepšie zachytávala nižšie úrovne populizmu, položka týkajúca sa manichejského pohladu stredné až vyššie úrovne. Položka týkajúca sa antielitárstva patrila medzi tri najinformatívnejšie položky a taktiež zachytávala vyššie úrovne populizmu. Ked'že mnohým existujúcim nástrojom na zistovanie populizmu často chýba presnost' v zachytávaní extrémnych prípadov (Van Hauwaert a kol., 2018; Castanho Silva a kol., 2020), autori predpokladali, že práve tieto tri položky budú v najredukovanejšej miere (bez prekrývania sa) zachytávat čo najširší rozsah populistických postojov vich komplexnej podobe. Tento predpoklad i potvrdili. Porovnaním všetkých troch verzií zistili, že osempoložková verzia je najinformatívnejšia a má najväčšie pokrytie (medzi položkami však dochádza k prekrývaniu), trojpoložková verzia má však oproti nej len minimálnu mieru zhoršenia.

Validita škál bola overená i preskúmaním súvislostí s volebnými zámermi, pričom nezávisle od jej rozsahu, respondenti, ktorí mali $v$ úmysle podporovat' populistickú politickú stranu, mali i vyššiu úroveň populistických postojov (zistovanú troj-, šest'- i osempoložkovou verziou škály). I ked' krátke verzie škál majú svoje riziká (napr. Bakker \& Lelkes, 2018, in Van Hauwaert a kol., 2020) a položky najkratšej verzie boli navrhnuté na základe empirického a nie teoretického zhodnotenia, autori poukazujú na to, že i škála s tromi položkami môže poskytnút obdobné informácie a výsledky ako rozsiahlejšie verzie (Van Hauwaert a kol., 2020).

\section{Zhrnutie}

Na základe toho, že populizmus je najčastejšie vymedzený ako myšlienkový konštrukt, ktorý sa ako súbor myšlienok môže prejavovat' na individuálnej úrovni, je možné ho merat' (Akkermanová a kol., 2014; Hawkins a kol., 2012; Stanley 2011). Tieto sklony, resp. populistické postoje nemožno priamo pozorovat', t. j. sú latentné. Možno ich opísat' ako tendenciu, ktorá je vyjadrená hodnotením konkrétnej entity s určitým stupňom priazne alebo nepriazne (Eagly \& Chaiken 1993, in Van Hauwaert a kol., 2018), kde tzv. "entita“ je v súlade $s$ myšlienkami populizmu. Konkrétne sa tieto myšlienky týkajú antielitárstva, inherentnej viery vo všeobecnú alebo vôlu l'udu a manichejského svetonázoru (Hawkins 2009, in Van Hauwaert a kol., 
2020), resp. antielitárstva, centrizmu l'udí a antipluralizmu (vid' Castanho Silva a kol., 2020).

Na základe tohto teoretického chápania skúmali viaceré empirické štúdie možnosti zist́ovania a merania populistických postojov a predkladali série rôznych položiek a škál, ktoré sú aktuálne $\mathrm{k}$ dispozícii k d'alšiemu skúmaniu. $\checkmark$ nasledujúcom texte ich zosumarizujeme a poukážeme na tri medzníky v genéze ich vývoja.

Jednými z prvých empirických výskumov týkajúcich sa populistických postojov boli práce Stanleyho (2011) a Hawkinsa a kol. (2012), ktoré vznikli v obdobnom čase na rôznych stranách Atlantiku. Stanley (2011) vytvoril osem položiek s likertovou škálou na zistovanie populizmu u slovenských respondentov. Tie sa týkali štyroch konceptov: homogenity skupín lud a elita ( 2 položky), antagonistického charakteru politického života (2 položky), postojov k demokracii ( 2 položky) a morálneho rozmeru politiky (2 položky). Hawkins a kol. (2012) s dôrazom na precíznejšiu definíciu populizmu a taktiež teoretické, resp. i empirické vymedzenie konštruktu voči dvom hlavným protikladom - pluralizmu a elitárstvu, navrhli štvorpoložkovú škálu (resp. šestípoložkovú po zahrnutí dvoch položiek tzv. skrytej demokracie - konceptu Hibbinga a Theiss-Morseho (2002, in Hawkins a kol., 2012)). Dôraz v nich bol podl'a autorov kladený najmä na manichejské vnímanie politiky. Vzhl'adom ktomu, že vymedzenie populizmu voči iným/blízkym konštruktom umožňuje lepšiu kontrolu jeho validity, je možné považovat' tento aspekt ich výskumu za prvý dôležitý medzník v genéze vývoja populistických škál. Túto dôležitú skutočnost' zohl'adnili aj ich nasledovníci, Akkermanová a kol. (2014), ktorí škálu Hawkinsa a kol. (2012) rozšírili na šest́položkovú verziu. Podl'a autorov ňou zachytávali tri hlavné znaky populizmu, ktoré ho definujú, a to l'udovú suverenitu, opozíciu ludí voči elitám (resp. rozlíšenie medzi lud'mi a elitou) a manichejské rozlíšenie medzi dobrom (l'udom) a zlom (elitami). (Istou zaujímavost́ou je, že dve položky, ktoré $z$ ich verzie škály populizmu (u holandských respondentov, resp. veurópskom kontexte) faktorovaním vypadli, boli tie, ktoré boli (u amerických respondentov) súčastou pôvodnej štvorpoložkovej verzie (t. j. Politika je v konečnom dôsledku bojom medzi dobrom a zlom a Záujmové skupiny majú príliš vel'ký vplyv na politické rozhodnutia)). Vzhl'adom ktomu, že $v$ rámci prvotných empirických výskumov vo väčšej miere rezonoval dôraz na validitu konštruktu, nie je prekvapujúce, že autori potvrdzujú jeho platnost' aj súvislostami 
s volebným správaním (čo sa im na rozdiel od Stanleyho (2011) výskumu i podarilo). Vypadnutie položiek týkajúcich sa "silných formulácií" súvisiacich s manichejským rozdelením spoločnosti prirodzene neostalo nepovšimnuté. Elchardus a Spruyt (2016) svojou štvorpoložkovou škálou úplne vypustili tento pôvodne dôležitý aspekt (vid' prvotné výskumy, napr. Hawkins a kol. (2012)) a populizmus koncipovali prostredníctvom iných aspektov (t. j. prostredníctvom centrizmu ludí a jemnejších foriem antisystémových nálad, t. j. antielitárstvo bolo zredukované na opozíciu len voči vládnym elitám). I ked' autori potvrdili významné súvislosti s teoreticky relevantnými premennými (týkajúcimi sa potenciálnych príčin populizmu), vzhl'adom na vel'mi intenzívny súhlas väčšiny respondentov s jednotlivými položkami, je otázne, či autori skutočne zistóvali populistické postoje. Následne sa výskum zist́ovania populistických postojov posunul k d'alšiemu významnému medzníku, ktorým bolo operacionalizovanie populizmu ako viacdimenzionálneho konštruktu. I ked' rôzne aspekty/komponenty boli súčastou vymedzenia populizmu viac menej stále (vid'. predchádzajúce výskumy), položky zachytávali rôzne dimenzie simultánne $v$ jednorozmernej škále. Zmena v uvedenom operacionalizovaní znamenala, že predkladanými položkami sa začali zachytávat' jednotlivé dimenzie oddelene. Zmena sa týkala i spôsobu generovania finálnych položiek jednotlivých dimenzií, t. j. začali sa vytvárat' z vel'kého počtu položiek (teda empiricky) prostredníctvom štatistických procedúr (a nielen na základe teórie ako v prípade predchádzajúcich výskumov). Okrem otázky identifikovania podstatných, resp. rozhodujúcich komponentov/dimenzií, bolo ciel’om nadchádzajúcich výskumov i zodpovedanie otázky týkajúcej sa potenciálnych vztahov medzi nimi. Odpovede jednotlivých autorov sa pritom rôznia. Schulzová a kol. (2018) identifikovali antielitárstvo, ludovú suverenitu a homogenitu a čestnost' luudí. Oliver a Rahnová (2016) identifikovali antielitárstvo, nedôveru voči odborníkom a národnú príslušnost'. Hoboltová a kol. (2016) sa trochu iným prístupom zamerali na "základné témy“ populizmu, a to postoje $\mathrm{k}$ politickým elitám; k zastupitel'skej demokracii \& vláde väčšiny a k l'ud'om mimo väčšinovú skupinu. Napokon Castanho Silva a kol. (2018) identifikovali antielitárstvo, centrizmus l'udí a manichejské vnímanie, ktoré sa vd'aka ich výskumu opätovne dostalo do popredia ako dôležitý, ale najmä exkluzívny aspekt populizmu.

Autori sa lí̌ili i vodpovediach týkajúcich sa vztahov medzi jednotlivými dimenziami. Oliver a Rahnová (2016) merali jednotlivé dimenzie oddelene 
a rovnako separátne (s nimi) uskutočňovali i jednotlivé analýzy, Schulzová a kol. (2018) vnímali populizmus ako nadradený a latentný konštrukt, pričom sú nevyhnutné všetky dimenzie, aby bol jedinec populistom (korelácia medzi dimenziami vytvára úplnost' konceptu). Na druhej strane, Castanho Silva a kol. (2018) nepredpokladali koreláciu medzi dimenziami.

Ako je evidentné, i ked' všetci spomínaní autori vychádzali z Muddeho (vid' výskumy vyššie) definície populizmu, existuje vel'ká variabilita v tom, ktoré aspekty napokon autori vo svojich výskumoch zdôraznili a ako populizmus operacionalizovali. Táto skutočnost' viedla knajaktuálnejšiemu medzníku vo výskume zameranom na zistovanie populistických postojov, ktorým je tendencia porovnávat' jednotlivé škály, resp. identifikovat tú škálu, resp. položky, ktoré sú najvhodnejšie (najvalidnejšie), a to ajs ohl'adom na medzinárodný výskum (napr. Castanho Silva a kol, 2020).

$V$ tejto súvislosti uvedieme zistenia pravdepodobne jedného z najkomplexnejších porovnaní, výskum Castanho Silvu a kol. (2020), ktorí porovnali sedem populistických škál (Akkermanová a kol., 2014; Castanho Silva a kol., 2018; Elchardus \& Spruyt, 2016; Hoboltová a kol., 2016; Oliver \& Rahnová, 2016; Schulzová a kol., 2018; Stanley, 2011).

Zhodnotením vnútornej koherencie (internal coherence) (prostredníctvom konfirmačnej faktorovej analýzy - CFA) zistili, že len tri škály mali adekvátne vlastnosti (dobré ukazovatele model fit a vysoké sýtenie adekvátneho faktora (high factor loadings)), a to Akkermanovej a kol. (2014); Schulzovej a kol. (2018); a Castanho Silvu a kol. (2018). Odstránením jednej neadekvátnej položky boli akceptovatel'né i škály Elchardusa a Spruyta (2016), resp. Hoboltovej a kol. (2016) CSES modul.

Medzinárodná validita (prostredníctvom testovania invariancie) všetkých škál však bola nízka, resp. stredná. Najvyššiu úroveň invariantného faktorového sýtenia (invariant factor loadings) naprieč rôznymi krajinami mala len škála Castanho Silvu a kol. (2018), resp. čiastočne i škála Akkermanovej a kol. (2014).

Vzhladom k tomu, že dobrá batéria by mala zahŕňat' polarizujúce položky, t. j. položky, s ktorými budú súhlasit́ iba respondenti s vysokou alebo iba s nízkou úrovňou populizmu, je dôležité identifikovat' i šírku konceptu, ktorá je škálou zachytávaná (zistované prostredníctvom IRT). Autori zistili, že žiadna z testovaných škál nezachytila ideálny rozsah od minimálnej po maximálnu úroveň populizmu (škály dobre identifikovali skôr stredné 
úrovne populizmu). Škály Akkermanovej a kol. (2014); Stanleyho (2011) a Castanho Silvu a kol. (2018) však boli tie, ktoré zachytávali najširší rozsah mali najširšiu informačnú krivku.

Externá validita škál bola overovaná prostredníctvom súvislostí s politickou dôverou (political trust), vierou $v$ konšpirácie (belief in conspiracies) a stotožnenie sa $s$ populistickými stranami (identification with populist parties). U všetkých škál sa preukázali stredné až silné súvislosti $s$ uvedenými premennými, pričom $s$ ohladom na poslednú $z$ uvedených je podstatné, že súvislosti boli preukázané ako s pravicovo tak i l'avicovo orientovanými populistickými stranami.

Záverom ich porovnania bolo konštatovanie, že škála Castanho Silvu a kol. (2018) mala napriek dobrým psychometrickým vlastnostiam len strednú schopnost' predikovat' podporu populistických politických strán. Škála Akkermanovej a kol. (2014) a Schulzovej a kol. (2018) na druhej strane mali napriek akceptovatel'ným až dobrým psychometrickým vlastnostiam nízku medzinárodnú validitu.

Ako je zrejmé, existuje vel'ká heterogenita v ponúkaných nástrojoch na zistovanie populistických postojov, pričom sú tiež rozdiely $v$ ich psychometrických vlastnostiach. Je preto žiadúce, aby výskum týkajúci sa merania populistických postojov nad'alej pokračoval. Na základe predložených informácií je tiež dôležité, aby bolo použitie dostupných škál $v$ d'alších výskumoch vždy s ohl'adom na kontrolu ich psychometrických vlastností. Napokon je potrebné sa aj zamysliet', či a do akej miery je populizmus kontextovo špecifickým konštruktom, t. j. či sa určité dimenzie líšia (prípadne sú ovplyvnené) krajinou (čo napr. naznačujú testy invariancie, napr. Castanho Silva a kol., 2020, Van Hauwaert a kol., 2018). Záverom je však treba zdôraznit', že pokrok, ktorý v súvislosti s meraním populizmu vd'aka intenzívnemu výskumu nastal, je evidentný a je prínosom pre d'alšie vedecké skúmanie. 


\section{ZOZNAM POUŽITEJ LITERATÚRY}

Aalberg, T., Esser, F., Reinemann, C., Stromback, J., \& de Vreese, C. H. (2017). Populist Political Communication in Europe. New York: Routledge.

Abalakina-Paap, M., Stephan, W. G., Craig T., \& Gregory, W. L. (1999). Beliefs in Conspiracies. Political Psychology, 20(3), 637-647. https://doi.org/10.1111/0162-895X.00160

Ahmed, W., Vidal-Alaball, J., Downing, J., \& López Seguí, F. (2020). COVID19 and the 5G Conspiracy Theory: Social Network Analysis of Twitter Data. Journal of Medical Internet Research, 22(5), e19458. https://doi.org/10.2196/19458

Aigigner, K. (2020). Populism: Root Causes, Power Grabbing and Counter Strategy. Intereconomics, 55(1), 38-42. https://doi.org/10.1007/s10272-020-0867-3

Akkerman, A., Mudde, C., \& Zaslove, A. (2014). How Populist Are the People? Measuring Populist Attitudes in Voters. Comparative Political Studies, 47(9), 1324-1353. https://doi.org/10.1177/0010414013512600

Andreadis, I., Cremonesi, C., Kartsounidou, E., Kasprowicz, D., \& Hess, A. (2019). Attitudinal and Behavioral Responses to Populist Communication: The Impact of Populist Message Elements on Populist Attitudes and Voting Intentions. In C. Reinemann, J. Stanyer, T. Aalberg, F. Esser, \& C.H. de Vreese (Eds.), Communicating Popusims. Comparing Actor Perceptions, Media Coverage, and Effects on Citizens in Europe (s. 207-232). New York: Routledge.

Aslanidis, P. (2018). The Social Psychology of Populism. Dostupné online: https://www.researchgate.net/publication/322702926 The Social Ps ychology of Populism

Aslanidis, P. (2017). Avoiding Bias in the Study of Populism. Chinese Political Science Review, 2, 266-287. https://doi.org/10.1007/s41111-017-0064$\underline{0}$ 
Aslanidis, P. (2016). Is Populism an Ideology? A Refutation and a New Perspective. Political Studies, 64(1), 88-104. https://doi.org/10.1111/1467-9248.12224

Aslanidis, P. (2011). Populism in Eastern and Southeastern Europe. MA Thesis: University of Macedonia.

Bakker, B. N., Rooduijn, M., \& Schumacher, G. (2015). The psychological roots of populist voting: Evidence from the United States, the Netherlands and Germany. European Journal of Political Research, 55(2), 302-320. https://doi.org/10.1111/1475-6765.12121

Barkun, M. (2013). A culture of conspiracy: Apocalyptic visions in contemporary America. Berkeley, California: University of California Press.

Bergmann, E. (2018). Conspiracy \& Populism. Palgrave Macmillan.

Bernhard, L., \& Hänggli, R. (2018). Who holds populist atttitudes? Evidence from Switzerland. Swiss Political Science Review, 24(4), 510-534. https://doi.org/10.1111/spsr.12326

Bittó Cigániková, J. (2020). Pozrite si zoznam káuz vlád Smeru za 7 miliárd. Nenechajte sa kúpit' omrvinkami. SME blog. https://jankaciganikova.blog.sme.sk/c/528084/pozrite-si-zoznamkauz-vlad-smeru-za-7-miliard-nenechajte-sa-kupit-omrvinkami.html

Bonikowski, B., Halikiopoulou, D., Kaufmann, E., \& Rooduijn, M. (2018). Populism and nationalism in a comparative perspective: a scholarly exchange. Nations and Nationalism, 1-14.

Bos, L., Schemer, Ch., Corbu, N., Hamellers, M., Andreadis, I., Schulz, A., Schmuck, D., Reinemann, C., \& Fawzi, N. (2020). The effect of populism as a social identity frame on persuasion and mobilisation: Evidence from a 15-country experiment. European Journal of Political Research, 59(1), 3-24. https://doi.org/10.1111/1475-6765.12334

Boscán, G., Llamazares, I., \& Wiesehomeier, N. (2018). Populist Attitudes, Policy Preferences, and Party Systems in Spain, France, and Italy. Revista Internacional de Sociología, 76(4), e110. https://doi.org/10.3989/ris.2018.76.4.18.001 
Bozogáňová, M., \& Lorincová, T. (2019). Atittudes towards migrants in the Slovak population based on Eurobarometer data (2017). In J. Procházka, T. Kratochvíl, \& M. Vaculík (Eds.), Psychologie práce a organizace 2019 (s. 91-100). Masaryk university press: Brno. https://doi.org/10.5817/CZ.MUNI.P210-9488-2019-9

Bruder, M., Heffke, P., Neave, N., Nouripanah, N., \& Imhoff, R. (2013). Measuring Individual Differences in Generic Beliefs in Conspiracy Theories Across Cultures: Conspiracy Mentality Questionnaire. Frontiers in Psychology, 4(225), 1-15. https://doi.org/10.3389/fpsyg.2013.00225

Carey, J. M., Chi, V., Flynn, D. J., Nyhan, B., \& Zeitzoff, T. (2020). The effects of corrective information about disease epidemics and outbreaks: Evidence from Zika and yellow fever in Brazil. Science Advances, 6(5), eaaw7449. https://doi.org/10.1126/sciadv.aaw7449

Castanho Silva, B., Jungkunz, S., Helbling, M., \& Littvay, L. (2020). An Empirical Comparison of Seven Populist Attitudes Scales. Political Research Quarterly, 73(2), 409-424. https://doi.org/10.1177/1065912919833176

Castanho Silva, B., Andreadis, I., Anduiza, E., Blanuša, N., Corti, Y. M., Delfino, G., Rico, G. et al. (2018). Public Opinion Surveys: A New Scale. In K. A. Hawkins, R. Carlin, L. Littvay, \& C. Rovira Kaltwasser (Eds.), The Ideational Approach to Populism: Concept, Theory, and Analysis (s. 150178). London: Routledge.

Corbu, N., Bos. L., Schemer, Ch., Schulz, A., Matthes, J., de Vreese, C.H., Aaberg, T., \& Suiter, J. (2019). Cognitive Responses to Populist Communication: The Impact of Populist Message Elements on Blame Attribution and Stereotyping. In C. Reinemann, J. Stanyer, T. Aalberg, F. Esser, \& C.H. de Vreese (Eds.), Communicating Popusims. Comparing Actor Perceptions, Media Coverage, and Effects on Citizens in Europe (s. 183-206). New York: Routledge.

Čikovský, K. (2015). Pät' miliardových káuz Smeru. Denník E. https://e.dennikn.sk/303618/pat-miliardovych-kauz-smeru/

de la Torre, C. (2010). Populist Seduction in Latin America. 2nd ed. Athens: Ohio University Press.

Dentith, M. R. X., \& Orr, M. (2017). Secrecy and conspiracy. Episteme, 118. https://doi.org/10.1017/epi.2017.9 
de Vreese, C. H., Esser, F., Aalberg, T., Reinemann, C., \& Stanyer, J. (2018). Populism as an Expression of Political Communication Content and Style: A New Perspective. The International Journal of Press/Politics, 23(4), 423-438. https://doi.org/10.1177/1940161218790035

de Vreese, C. H., Reinemann, C., Stanyer, J., Esser, F., \& Aalberg, T. (2019). Adapting to the Different Shades of Populism: Key Findings and Implications for Media, Citizens, and Politics. In C. Reinemann, J. Stanyer, T. Aalberg, F. Esser, \& C.H. de Vreese (Eds.), Communicating Popusims. Comparing Actor Perceptions, Media Coverage, and Effects on Citizens in Europe (s. 235-252). New York: Routledge.

Douglas, K., Uscinski, J., Sutton, R., Cichocka, A., Nefes, T., Ang, C., \& Deravi, F. (2019). Understanding Conspiracy Theories. Political Psychology, 40(S1), 3-35. https://doi.org/10.1111/pops.12568

Doyle, D. (2011). The Legitimacy of Political Institutions: Explaining Contemporary Populism in Latin America. Comparative Political Studies, 44(11), 1447-1473. https://doi.org/10.1177/0010414011407469

Drochon, H. (2018). Who believes in conspiracy theories in Great Britain and Europe? In J. E. Uscinski (Ed.), Conspiracy theories and the people who believe them (s. 337-346). New York, NY: Oxford University Press.

Eberl, J., Huber, R., \& Greussing, E. (2021). From populism to the "plandemic": why populists believe in COVID-19 conspiracies. Journal of Elections, Public Opinion and Parties, 31(sup1), 272-284. https://doi.org/10.1080/17457289.2021.1924730

ElectionGuide (2021). Dostupné

online: https://www.electionguide.org/elections/

Elchardus, M., \& Spruyt, B. (2016). Populism, Persistent Republicanism and Declinism: An Empirical Analysis of Populism as a Thin Ideology. Government \& Opposition, 51(1), 111-133. https://doi.org/10.1017/gov.2014.27

Enders, A. M., \& Smallpage, S. M. (2018). Polls, plots, and party politics: Conspiracy theories in contemporary America. In J. E. Uscinski (Ed.), Conspiracy theories and the people who believe them (s. 298-318). New York: Oxford University Press. 
Erisen, C., Guidi, M., Martini, S., Toprakkiran, S., Isernia, P., \& Littway, L. (2021). Psychological Correlates of Populist Attitudes. Advances in Political Psychology. https://doi.org/10.1111/pops.12768

Evans, J., \& Hargittai, E. (2020). Who Doesn't Trust Fauci? The Public's Belief in the Expertise and Shared Values of Scientists in the COVID-19 Pandemic. Socius: Sociological Research For A Dynamic World, 6, 237802312094733. https://doi.org/10.1177/2378023120947337

Fatke, M. (2019). The personality of populists: How the Big Five traits relate to populist attitudes. Personality and Individual Differences, 139, 138151. https://doi.org/10.1016/j.paid.2018.11.018

Fawzi N. (2018). Untrustworthy news and the media as "enemy of the people?" How a populist worldview shapes recipients' attitudes toward the media. International Journal of Press/Politics, 24, 146-164. https://doi.org/10.1177/1940161218811981

Findor, A., Hruška, M., Jankovská, P., \& Pobudová, M. (2021). Re-examining public opinion preferences for migrant categorizations: "Refugees" are evaluated more negatively than "migrants" and "foreigners" related to participants' direct, extended, and mass-mediated intergroup contact experiences. International Journal of Intercultural Relations, 80, 262273. https://doi.org/10.1016/j.ijintrel.2020.12.004

Freelon, D., \& Wells, C. (2020). Disinformation as political communication. Political Communication, 37(2), 145-156. https://doi.org/10.1080/10584609.2020.1723755

Fritsche, I., Moya, M., Bukowski, M., Jugert, P., de Lemus, S., Decker, O., Valor-Segura, I., \& Navarro-Carrillo, G. (2017). The great recession and group-based control: Converting personal helplessness into social class in-group trust and collective action. Journal of Social Issues, 73(1), 117137. https://doi.org/10.1111/josi.12207

Funke, M., Schularick, M., \& Trebesch, C. (2021). The cost of populism: Evidence from history. VOX ${ }^{E U}$ CEPR. Dostupné online: https://voxeu.org/article/cost-populism-evidence-history 
Funke, M., Schularick, M., \& Trebesch, C. (2020). Populist Leaders and the Economy, CEPR Discussion Paper No. 15405. https://cepr.org/active/publications/discussion papers/dp.php?dpno= $\underline{15405}$

Funtowicz, S., \& Jerome R. (1993). Science for the Post-Normal Age. Futures, 25, 739-755. https://doi.org/10.1016/0016-3287(93)90022-L

Galais, C., \& Rico, G. (2021). An unjustified bad reputation? The Dark Triad and support for populism. Electoral Studies, 72. https://doi.org/10.1016/j.electstud.2021.102357

Galliford, N., \& Furnham, A. (2017). Individual difference factors and beliefs in medical and political conspiracy theories. Scandinavian Journal of Psychology, 58(5), 422-428. https://doi.org/10.1111/sjop.12382

Gallo Kriglerová, E., Kadlečíková, J., Holka Chudžíková, A., \& Píšová, M. (2021). Cudzie nechceme, svoje si nedáme. Postoje majoritnej populácie $k$ migrácii a cudzincom na Slovensku. Analýza kvantitatívneho a kvalitatívneho výskumu. Bratislava: Centrum pre výskum etnicity a kultúry. Dostupné online: http://cvek.sk/?attachment id=2877\&download=true

Geurkink, B., Zaslove, A., Sluiter, R., \& Jacobs, K. (2020). Populist Attitudes, Political Trust, and External Political Efficacy: Old Wine in New Bottles? Political Studies, 68(1), 247-267. https://doi.org/10.1177/0032321719842768

Gidron, N., \& Bonikowski, B. (2013). Varieties of Populism: Literature Review and Research Agenda. Weatherhead Working Paper Series, No. 13-0004. Dostupné online: https://scholar.harvard.edu/files/gidron bonikowski populismlitrevie w 2013.pdf

Gidron, N., \& Hall, P.A. (2017). The politics of social status: economic and cultural roots of the populist right. British Journal of Sociology, 68, 5784. https://doi.org/10.1111/1468-4446.12319

Globsec. (2018, May 11). GLOBSEC trends 2018 Central Europe: One region, different perspectives. Dostupné online: https://www.globsec.org/publications/globsec-trends-2018-centraleurope-one-region-differentperspectives/\#rRZ8rc9EUi6SZCCU.99 
Goertzel, T. (1994). Belief in Conspiracy Theories. Political Psychology, 15(4), 731-742. https://doi.org/10.2307/3791630

Gold, R., \& Fetzer, T. (2019). The economic causes of populism. Global Solutions Journal, 5. GSJ5 Gold Fetzer.pdf (global-solutionsinitiative.org)

Golec de Zavala, A. (2020). Why is populism so robustly associated with conspiratorial thinking? Collective Narcissism and the Meaning Maintenance Model. In J. D. Sinnott \& J. S. Rabin (Eds.), The psychology of political behavior in a time of change (s. 277-290). Cham, Switzerland: Springer International Publishing.

GOVUK (2020). Regional Ethnic Diversity. Office for National Statistics. Dostupné online: https://www.ethnicity-factsfigures.service.gov.uk/uk-population-by-ethnicity/national-andregional-populations/regional-ethnic-diversity/latest

Hajdu, D. \& Klingová, K. (2020). Voices of Central and Eastern Europe. Slovensko: Globsec Bratislava

Hameleers, M. (2021). They Are Selling Themselves Out to the Enemy! The Content and Effects of Populist Conspiracy Theories, International Journal of Public Opinion Research, 33(1), 3856, https://doi.org/10.1093/ijpor/edaa004

Hameleers, M. (2020). We Are Right, They Are Wrong: The Antagonistic Relationship Between Populism and Discourses of (Un)truthfulness. disClosure: A Journal of Social Theory, 29(12). https://doi.org/10.13023/disclosure.29.11

Hameleers, M., Andreadis, I., \& Reinemann, C. (2019). Investigating the Effects of Populist Communication: Design and Measurement of the Comparative Experimental Study. In C. Reinemann, J. Stanyer, T. Aalberg, F. Esser, \& C.H. de Vreese (Eds.), Communicating Popusims. Comparing Actor Perceptions, Media Coverage, and Effects on Citizens in Europe (s. 168-182). New York: Routledge.

Hameleers, M., Bos, L., \& de Vreese, C. H. (2017). Framing blame: Toward a better understanding of the effects of populist communication on populist party preferences. Journal of Elections, Public Opinion and Parties, 28(3),

380-398.

https://doi.org/10.1080/17457289.2017.1407326 
Hameleers, M., Bos, L., Fawzi, N., Reinemann, C., Andreadis, I., Corbu, N., \& Weiss, N. (2018). Start spreading the news: A comparative experiment on the effects of populist communication on political participation in 16 European countries. International Journal of Press/Politics, 23(4), 517-538. https://doi.org/10.1177/1940161218786786

Hameleers, M., \& de Vreese C. D. (2020). To whom are "the people" opposed? Conceptualizing and measuring citizens' populist attitudes as a multidimensional construct. Journal of Elections, Public Opinions and Parties, 30(2),

255-274.

https://doi.org/10.1080/17457289.2018.1532434

Hameleers, M., Reinemann, C., Schmuck, D., \& Fawzi, N. (2019). The Persuasiveness of Populist Communication: Conceptualizing the Effects and Political Consequences of Populist Communication From a Social Identity Perspective. In C. Reinemann, J. Stanyer, T. Aalberg, F. Esser, \& C.H. de Vreese (Eds.), Communicating Popusims. Comparing Actor Perceptions, Media Coverage, and Effects on Citizens in Europe (s. 143167). New York: Routledge.

Hawkins, K. A. (2009). Is Chávez Populist?: Measuring Populist Discourse in Comparative Perspective. Comparative Political Studies, 42(8), 10401067. https://doi.org/10.1177\%2F0010414009331721

Hawkins, K. A. (2010). Venezuela's Chavismo and Populism in Comparative Perspective. Cambridge: Cambridge University Press.

Hawkins, K. A., Carling, R., Littvay, L., \& Rovira Kaltwasser, C. (2019). The Ideational Approach to Populism: Concept, Theory, and Analysis. New York: Routledge.

Hawkins, K. A., Riding, S., \& Mudde, C. (2012). Measuring Populist Attitudes. C\&M working paper \#55. University of Georgia. Dostupné online: https://works.bepress.com/cas mudde/72/download

Henley, J., \& Duncan, P. (2020). European support for populist beliefs falls, YouGov Survey suggests. The Guardian. https://www.theguardian.com/world/2020/oct/26/european-supportfor-populist-beliefs-falls-yougov-survey-suggests 
Hobolt, S., Anduiza, E., Carkoglu, A., Lutz, G., \& Sauger, N. (2016). Democracy Divided? People, Politicians and the Politics of Populism. Dostupné online: https://cses.org/wpcontent/uploads/2019/03/CSES5 ContentSubcommittee FinalReport. $\underline{\mathrm{pdf}}$

Imhoff, R., \& Bruder, M. (2014). Speaking (un-) truth to power: Conspiracy mentality as a generalised political attitude. European Journal of Personality, 28(1), 25-43. https://doi.org/10.1002/per.1930

Imhoff, R., \& Lamberty, P. (2018). How paranoid are conspiracy believers? Toward a more fine-grained understanding of the connect and disconnect between paranoia and belief in conspiracy theories. European Journal of Social Psychology, 48, 909-926. https://doi.org/10.1002/ejsp.2494

Jagers, J., \& Walgrave, S. (2007). Populism as Political Communication Style: An Empirical Study of Political Parties Discourse in Belgium. European Journal of Political Research, 46(3), 319-345. https://doi.org/10.1111/j.1475-6765.2006.00690.x

Jansen, R. S. (2011). Populist mobilization: A new theoretical approach to populism, Sociological Theory, 29(2), 75-96. https://doi.org/10.1111\%2Fj.1467-9558.2011.01388.x

Katsambekis, G. (2020). Constructing "the people“ of populism: a critique of the ideational approach from a discursive perspective. Journal of Political Ideologies, https://doi.org/10.1080/13569317.2020.1844372

Keeley, B. L. (1999). Of conspiracy theories. Journal of Philosophy, 96, 109126. https://doi.org/10.2139/ssrn.1084585

Klingová, K. (2019, February 27). Which Slovaks believe in conspiracy theories? Dostupné online: https://www.globsec.org/which-slovaksbelieve-in-conspiracy-theories/

Krastev, I. (2016). The Unraveling of the Post-1989 Order. Journal of Democracy, 27(4), 5-15.

Kurzban, R. \& Leary, M. (2001). Evolutionary Origins of Stigmatization: The Functions of Social Exlusion. Psychological Bulletin 127(2), 187-208. https://doi.org/10.1037/0033-2909.127.2.187

Laclau, E. (2005). On populist reason. London: Verso 
Landmann, H., Gaschler, R., \& Rohmann, A. (2019). What it threatening about refugees? Identifying different types of threat and their asscociation with emotional responses and attitudes towards refugee migration. European Journal of Social Psychology, 49(7), 1-56. https://doi.org/10.1002/ejsp.2593

Leibovitz, T., Shamblaw, A., Rumas, R., \& Best, M. (2021). COVID-19 conspiracy beliefs: Relations with anxiety, quality of life, and schemas. Personality And Individual Differences, 175, 110704. https://doi.org/10.1016/i.paid.2021.110704

Lupták, L'., \& Lupták Burzová, P. (2012). Mečiar, Fico a charizmatické panstvo. Acta Fakulty filozofické Západočeské univerzity v Plzni, 3, 5979. https://dspace5.zcu.cz/bitstream/11025/6311/1/luptak.pdf

Lewis, G. J., \& Bates, T. C. (2013). Common heritable effects underpin concerns over norm maintenance and in-group favoritism: Evidence from genetic analyses of right-wing authoritarianism and traditionalism. Journal of Personality, 82, 297-309. https://doi.org/10.1111/jopy.12055

Marcos-Marne, H. (2021). The Effects of Basic Human Values on Populist Voting. An Analysis of 13 European Democracies. Political Behavior. https://doi.org/10.1007/s11109-021-09689-8

Marcus, G. (2021). The rise of populism: The politics of justice, anger, and grievance. In J. P. Forgas, W. D. Crano, \& K. Fiedler (Eds.), The psychology of populism: The tribal challenge to liberal democracy (s. 81-104). London: Routledge.

Marušiak, J. (2006). Fenomén strany Smer: medzi „pragmatizmom“ a sociálnou demokraciou. Central European Political Studies Review, 8(1), 19-55. http://akademickyrepozitar.sk/Juraj-Marusiak/fenomen-stranysmer-medzi-pragmatizmom-a-socialnou-demokraciou.pdf

Marwick, A., \& Lewis, R. (2017). Media manipulation and disinformation online (s. 1-104). Data and Society Research Institute. Dostupné online: https://datasociety.net/wpcontent/uploads/2017/05/DataAndSociety MediaManipulationAndDis informationOnline-1.pdf 
Mayer, S. J., Berning, C. C., \& Johann, D. (2020). The Two Dimensions of Narcissistic Personality and Support for the Radical Right: The Role of Right-wing Authoritarianism, Social Dominance Orientation and Antiimmigrant Sentiment. European Journal of Personality, 34(1), 60-76. https://doi.org/10.1002/per.2228

Moffitt, B., \& Tormey, S. (2014). Rethinking populism: Politics, mediatisation and political style. Political Studies, 62(2), 381-397. https://doi.org/10.1111\%2F1467-9248.12032

Monot, J. C. (2017). Between post-truth and epistemocracy: Positioning a democratic politics. Esprit, 1-7. Dostupné online: https://www.eurozine.com/between-post-truth-andepistemocracypositioning-a-democratic-politics/.

Mudde, C. (2019). The Far Right Today. UK: Polity

Mudde, C. (2007). Populist Radical Right Parties in Europe. Cambridge: Cambridge University Press.

Mudde, C. (2004). The populist zeitgeist. Government and Opposition 39(4), 541-563. https://doi.org/10.1111/j.1477-7053.2004.00135.x

Mudde, C., \& Rovira Kaltwasser, C. (2017). Populism: A very short introduction. Oxford, UK: Oxford University Press. https://doi.org/10.1093/actrade/9780190234874.001.0001

Mudde, C., \& Rovira Kaltwasser, C. (2012a). Populism: corrective and threat to democracy. In C. Mudde, \& C. Rovira Kaltwasser (Eds.), Populism in Europe and the America: Threat or Corrective for Democracy? (s. 205222). Cambridge: Cambridge University Press.

Mudde, C., \& Rovira Kaltwasser, C. (2012b). Populism and (liberal) democracy: a framework for analysis. In C. Mudde, \& C. Rovira Kaltwasser (Eds.), Populism in Europe and the Americas: Threat or Corrective for Democracy? (s. 1-26). Cambridge: Cambridge University Press.

Muro, D. (2017). Let the people rule. Definitions and theories of populism. In Woertz, E. (Ed.), Populism in Europe: from symptom to alternative (s. 9-14). Barcelona: Center for International Affairs. 
Obradović, S., Power, S. A., \& Sheehy-Skeffington, J. (2020). Understanding the psychological appeal of populism. Current Opinion in Psychology, 35, 125-131. https://doi.org/10.1016/j.copsyc.2020.06.009

Oliver, J. E., \& Rahn, W. M. (2016). Rise of the Trumpenvolk: Populism in the 2016 Election. ANNALS of the American Academic of Political and Social Science, 667(1), 189-206. https://doi.org/10.1177/0002716216662639

Oliver, J. E., \& Wood, T. J. (2014). Conspiracy Theories and the Paranoid Style(s) of Mass Opinion. American Journal of Political Science, 58(4), 952-966. https://doi.org/10.1111/ajps.12084

Passarelli, G., \& Tuorto, D. (2018). The Five Star Movement: Purely a Matter of Protest? The Rise of a New Party between Political Discontent and Reasoned Voting. Party Politics, 24(2), 129-140. https://doi.org/10.1177\%2F1354068816642809

Pelinka, A. (2008). The Rise of Populism. In H. Swoboda, \& M. J. Wiersma (Eds.), Democracy, populism and minority rights (s. 39-48). https://www.socialistsanddemocrats.eu/sites/default/files/2632 EN democracy-populism ANTILOPE 1.pdf

Plenta, P. (2020). Conspiracy theories as a political instrument: utilization of anti-Soros narratives in Central Europe. Contemporary Politics, 26(5), 512-530. https://doi.org/10.1080/13569775.2020.1781332

Pruysers, S. (2020). A psychological predisposition towards populism? Evidence from Canada. Contemporary Politics, 27(1), 105-124. https://doi.org/10.1080/13569775.2020.1851930

Ramiro, L. (2016). Support for Radical Left Parties in Western Europe: Social Background, Ideology and Political Orientations. European Political Science Review, 8(1), 1-23. https://doi.org/10.1017/S1755773914000368

Rico, G., Guinjoan, M., \& Anduiza, E. (2020). Empowered and enraged: Political efficacy, anger, and support for populism in Europe. European Journal of Political Research, 59(4), 797-816. https://doi.org/10.1111/1475-6765.12374 
Rico, G., Guinjoan, M., \& Anduiza, E. (2017). The Emotional Underpinnings of Populism: How Anger and Fear Affect Populist Attitudes. Swiss Political Science Review, 23(4), 444-461. https://doi.org/10.1111/spsr.12261

Rooduijn, M. (2018). What Unites the Voter Bases of Populist Parties? Comparing the Electorates of 15 Populist Parties. European Political Science Review, 10(3),

351-368.

https://doi.org/10.1017/S1755773917000145

Rooduijn, M. (2019). State of the field: How to study populism and adjacent topics? A plea for both more and less focus. European Journal of Political Research, 58(1), 362-372. https://doi.org/10.1111/1475-6765.12314

Rooduijn, M., \& Pauwels, T. (2011). Measuring Populism: Comparing Two Methods of Content Analysis. West European Politics, 34(6), 12721283. https://doi.org/10.1080/01402382.2011.616665

Rooduijn, M., van der Brug, W., \& De Lange, S. L. (2016). Expressing or Fueling Discontent? The Relationship between Populist Voting and Political Discontent. Electoral Studies, 43(1), 32-40. https://doi.org/10.1016/j.electstud.2016.04.006

Rueda, D. (2021). Is Populism a Political Strategy? A Critique of an Enduring Approach. Political Studies, 69(2), 167-184. https://doi.org/10.1177/0032321720962355

Salgado, S., \& Stanyer, J. (2019). Perceptions of Populism and the Media: A Qualitative Comparative Approach to Studying the Views of Journalists and Politicians. In C. Reinemann, J. Stanyer, T. Aalberg, F. Esser, \& C.H. de Vreese (Eds.), Communicating Popusims. Comparing Actor Perceptions, Media Coverage, and Effects on Citizens in Europe (s. 1733). New York: Routledge.

Salgado, S., Stanyer, J. Hajzer, G., Hopmann, D.N., Kalsnes, B., Legnante, G., Lipiński, A., Merkovity, N., Papathanassopoulos, S., \& Sanders, K. B. (2019). Politicians' Perceptions of Populism and the Media: A CrossNational Study Based on Semi-Structured Interviews. In C. Reinemann, J. Stanyer, T. Aalberg, F. Esser, \& C.H. de Vreese (Eds.), Communicating Popusims. Comparing Actor Perceptions, Media Coverage, and Effects on Citizens in Europe (s. 51-69). New York: Routledge. 
Schulz, A., Müller, P., Schemer, Ch., Wirz, D. S., Wettstein, M., \& Wirth, W. (2018). Measuring Populist Attitudes on Three Dimensions. International Journal of Public Opinion Research, 30(2), 316-326. https://doi.org/10.1093/iipor/edw037

Schulze, H., Mauk, M., \& Linde, J. (2020). How populism and polarization affect Europe's Liberal Democracies. Politics and Governance, 8(3), 1-5. https://doi.org/10.17645/pag.v8i3.3460

Silva, B., Vegetti, F., \& Littvay, L. (2017). The Elite Is Up to Something: Exploring the Relation Between Populism and Belief in Conspiracy Theories. Swiss Political Science Review, 23(4), 423-443. https://doi.org/10.1111/spsr.12270

Slosiarik, M. (2019). Prieskumy verejnej mienky a populizmus. Dostupné online:

https://transparency.sk/wpcontent/uploads/2019/11/Populizmus TIS MS final-1.pdf

Spierings, N., \& Zaslove, A. (2017). Gender, populist attitudes, and voting: Explaining the gender gap in voting for populist radical right and populist radical left parties. West European Politics, 40(4), 821-847. https://doi.org/10.1080/01402382.2017.1287448

Spierings, N., \& Zaslove, A. (2015). Gendering the Vote for Populist RadicalRight Parties. Patterns of Prejudice, 49(1-2), 135-162. https://doi.org.com/10.1080/0031322X.2015.1024404

Spierings, N., Zaslove, A., Mügge, L. M., \& de Lange, S. L. (2015). Gender and Populist Radical-Right Politics: An Introduction. Patterns of Prejudice, 49(1-2), 3-15. https://doi.org.com/10.1080/0031322X.2015.1023642

Stanley, B. (2011). Populism, nationalism, or national populism? An analysis of Slovak voting behavior at the 2010 parliamentary election. Communist and Post-Communist Studies, 44(4), 257-270. https://doi.org/10.1016/j.postcomstud.2011.10.005 
Stanyer, J., Salgado, S., Bobba, G., Hajzer, G., Hopmann D., Hubé, N., Merkovity, N., Özerim, G., Papathanassopoulos, S., Sanders, K. B., Spasojevic, D., \& Vochocová, L. (2019). Journalists' Perceptions of Populism and the Media: A Cross-National Study Based on SemiStructured Interviews. In C. Reinemann, J. Stanyer, T. Aalberg, F. Esser, \& C.H. de Vreese (Eds.), Communicating Popusims. Comparing Actor Perceptions, Media Coverage, and Effects on Citizens in Europe (s. 3450). New York: Routledge.

Sunstein, C. R. \& Vermeule, A. (2009). Conspiracy theories: Causes and cures. Journal of Political Philosophy, 17, 202-227. https://doi.org/10.1111/j.1467-9760.2008.00325.x

Swoboda, H., \& Wiersma M. J. (2008). Consoliding New Democracies. In H. Swoboda, \& M. J. Wiersma (Eds.), Democracy, populism and minority rights (s. 9-22). Dostupné online: https://www.socialistsanddemocrats.eu/sites/default/files/2632 EN democracy-populism ANTILOPE 1.pdf

Štatistický úrad Slovenskej republiky (2020). Platné hlasy odovzdané pre politické subjekty podla územného členenia. Dostupné online: https://volby.statistics.sk/nrsr/nrsr2020/sk/data02.html

Tabellini, G. (2019). The Rise of Populism. VOX, CEPR Policy Portal. Dostupné online: https://voxeu.org/print/64713

Tajfel, H. (1974). Social Identity and Intergroup Behaviour. Social Science Information, 13(2),

65-93. https://doi.org/10.1177\%2F053901847401300204

Tajfel, H., \& Turner, J. C. (1979). An integrative theory of intergroup conflict. In W. G. Austin, \& S. Worchel (Eds.), The social psychology of intergroup relations (s. 33-37). Monterey, CA: Brooks/Cole.

Thomas, E. F., Mavor, K. I., \& McGarty, C. (2012). Social identities facilitate and encapsulate action-relevant constructs: A test of the social identity model of collective action. Group Processes \& Intergroup Relations, 15, 75-88. https://doi.org/10.1177/1368430211413619 
Thomas, E. F., Zubielevitch, E., Sibley, Ch. G., \& Osborne, D. (2020). Testing the Social Identity Model of Collective Action Longitudinally and Across Structurally Disadvantaged and Advantaged Groups. Personality and Social Psychology Bulletin, 46(6), 823-838. https://doi.org/10.1177/0146167219879111

Tonković, M., Dumančić, F., Jelić, M., \& Čorkalo Biruški, D. (2021). Who Believes in COVID-19 Conspiracy Theories in Croatia? Prevalence and Predictors of Conspiracy Beliefs. Frontiers In Psychology, 12. https://doi.org/10.3389/fpsyg.2021.643568

Urbinati, N. (2013). The populist phenomenon. Raisons Politiques, 51(3), 137-154. https://doi.org/10.3917/rai.051.0137

Uscinski, J. E., Enders, A. M., Klofstad, C. A., Seelig, M. I., Funchion, J. R., Everett, C., Wuchty, S., Premaratne, K., \& Murthi, M. N. (2020). Why do people believe COVID-19 conspiracy theories? Harvard Kennedy School (HKS) Misinformation Review. https://doi.org/10.37016/mr-2020-015

ÚPSVaR (2021). Zoznam najmenej rozvinutých okresov. 1. štvrt'rok 2021. https://www.upsvr.gov.sk/buxus/docs/statistic/NRO/Zoznam HD 10 2021 upr2 1.xlsx

Van Hauwaert, S. M., Schimpf, C. H., \& Azevedo, F. (2018). Public opinion surveys: Evaluating existing measures 1. In K. A. Hawkins, R. E. Carlin, L. Littvay, \& C. Rovira Kaltwasser (Eds.), The Ideational Approach to Populism: Concept, Theory, and Analysis (s. 128-149). London: Routledge.

Van Hauwaert, S. M., Schimpf, C. H., \& Azevedo, F. (2020). The measurement of populist attitudes: Testing cross-national scales using item response theory. Politics 40(1), 3-21. https://doi.org/10.1177\%2F0263395719859306

van Prooijen, J.-W., \& Jostmann, N. B. (2013). Belief in Conspiracy Theories: The Influence of Uncertainty and Perceived Morality. European Journal of Social Psychology, 43(1), 109-115. https://doi.org/10.1002/ejsp.1922 
van Prooijen, J.-W., \& van Vugt, M. (2018). Conspiracy Theories: Evolved Functions and Psychological Mechanisms. Perspectives on Psychological Science, 13(6), 770-788. https://doi.org/10.1177/1745691618774270

van Zomeren, M., Postmes, T., \& Spears, R. (2008). Toward an Integrative Social Identity Model of Collective Action: A Quantitative Research Synthesis of Three Socio-Psychological Perspectives. Psychological Bulletin, 134(4), 504-535. https://psycnet.apa.org/doi/10.1037/00332909.134.4.504

Vittori, D. (2017). Re-conceptualizing populism: Bringing a multifaceted concept within a stricter boarders. Revista Espaňola de Ciencia Política, 44, 43-65. https://doi.org/10.21308/recp.44.02

Visser, M., Lubbers, M., Kraaykamp, G. \& Jaspers E. (2014). Support for Radical Left Ideologies in Europe. European Journal of Political Research, 53(3), 541-558. https://doi.org/10.1111/ejpr.2014.53.issue-3

Weber, C. (2012). Emotions, campaigns, and political participation. Political Research Quarterly, 66(2), 414-428. https://doi.org/10.1177\%2F1065912912449697

Wettstein, M., Schulz, A., Steenbergen, M. R, Schemer, Ch., Müller, P., Wirz, D. S, \& Wirth, W. (2020). Measuring populism across nations: testing for measurement invariance of an inventory of populist attitudes. International Journal of Public Opinion Research, 32(2), 284-305. http://dx.doi.org/10.1093/ijpor/edz018

Weyland, K. (2017). Populism A Political-Strategic Approach. In C. Rovira Kaltwasser, P. Taggart, P. Ochoa Espejo, \& P. Ostiguy (Eds.), The Oxford Handbook of Populism (s. 53-84). Oxford: Oxford University Press.

Weyland, K. (2001). Clarifying a Contested Concept: Populism in the Study of Latin American Politics. Comparative Politics, 34(1), 1-22. https://doi.org/10.2307/422412

Whyte, C. (2020). Deepfake news: Al-enabled disinformation as a multilevel public policy challenge. Journal of Cyber Policy, 5(2), 199-217. https://doi.org/10.1080/23738871.2020.1797135 
Wirz, D. S. (2018). Persuasion through emotion? An experimental test of the emotion-eliciting nature of populist communication. International Journal of Communication, 12, 1114-1138. https://ijoc.org/index.php/ijoc/article/download/7846/2287

Wood, M. J., Douglas, K. M., \& Sutton, R. M. (2012). Dead and alive: Beliefs in contradictory conspiracy theories. Social Psychological and Personality Science, 3(6), 767-773. https://doi.org/10.1177/1948550611434786

Wormer, H. (2020). German Media and Coronavirus: Exceptional Communication - Or Just a Catalyst for Existing Tendencies? Media and Communication, 8(2), 467-470. https://doi.org/10.17645/mac.v8i2.3242

Wright, J. D., \& Esses, V. M. (2019). It's security, stupid! Voters' perceptions of immigrants as a security risk predicted support for Donald Trump in the 2016 US presidential election. Journal of Applied Social Psychology, 49(1), 36-49. https://doi.org/10.1111/jasp.12563

Zarocostas, J. (2020). How to fight an infodemic. The Lancet, 395(10225), 676. https://doi.org/10.1016/s0140-6736(20)30461-x 


\section{PRÍLOHY}

\section{PRÍLOHA 1}

The battery of populism-specific questions (Stanley, 2011)

1. The ordinary people are divided by many different values. *

2. The people who belong to the political elite are divided by many different values. *

3. Ordinary people are prevented from improving their lives by the actions of unaccountable elites.

4. Not all politicians are the same; some genuinely care about what the people want. *

5. Democracy is about finding compromise between different interests and opinions. *

6. Ordinary people are unable to make the correct decisions about the future of our country. *

7. The majority of politicians are honest people. *

8. Modern politics is in essence a struggle between the good, honest people and the evil elite.

* reverse scored 


\section{PRÍLOHA 2}

The populism questions (Hawkins et al., 2012)

1. Politics is ultimately a struggle between good and evil.

2. The politicians in Congress need to follow the will of the people.

3. The power of a few special interests prevents our country from making progress.

4. The people, not the politicians, should make the most important policy decisions.

The stealth democracy questions (Hibbing and Theiss-Morse's (2002) concept in Hawkins et al. (2012))

(Hawkins et al. (2012) suspect that the first two are capturing elements of populism, while the latter two are tapping into a third discourse that scholars often call elitism (Mudde, 2004, in Hawkins et al., 2012)).

1. Elected officials would help the country more if they would stop talking and just take action on important problems.

2. What people call 'compromise' in politics is really just selling out on one's principles.

3. Our government would run better if decisions were left up to successful business people.

4. Our government would run better if decisions were left up to nonelected, independent experts rather than politicians or the people.

The pluralism questions (Hawkins et al., 2012)

1. Democracy is about achieving compromise among differing viewpoints.

2. When our opposition presents new and challenging viewpoints, there is something we can learn by listening.

3. Freedom depends on diversity. 


\section{PRÍLOHA 3}

\section{Populist attitudes (Akkerman et al., 2014)}

(Items 1, 2, 6, 8+5, 7 adapted from Hawkins et al. (2012))

1. The politicians in the Dutch parliament need to follow the will of the people.

2. The people, and not politicians, should make our most important policy decisions.

3. The political differences between the elite and the people are larger than the differences among the people.

4. I would rather be represented by a citizen than by a specialized politician.

5. Elected officials talk too much and take too little action.

6. Politics is ultimately a struggle between good and evil. *

7. What people call "compromise" in politics is really just selling out on one's principles.

8. Interest groups have too much influence over political decisions. *

Pluralist attitudes (Items adapted from Hawkins et al. (2012), PLU3 reversed by Akkerman et al. (2014))

1. In a democracy it is important to make compromises among differing viewpoints.

2. It is important to listen to the opinion of other groups.

3. Diversity limits my freedom. *

Elitist attitudes (E2 a E3 from Hawkins et al. (2012), E1 added by Akkerman et al. (2014))

1. Politicians should lead rather than follow the people.

2. Our country would be governed better if important decisions were left up to successful business people.

3. Our country would be governed better if important decisions were left up to Independent experts.

* Left out of the analysis due to insufficient loading 


\section{PRÍLOHA 4}

The populism scale (Elchardus \& Spruyt, 2016)

1. The opinion of ordinary people is worth more than that of experts and politicians.

2. Politicians should listen more closely to the problems the people have.

3. Ministers should spend less time behind their desks and more among the ordinary people.

4. People who have studied for a long time and have many diplomas do not really know what makes the world go round. 


\section{PRÍLOHA 5}

\section{Dimensions of populism (Schulz et al., 2018)}

\section{Anti-elitist attitudes}

1. MPs in Parliament very quickly lose touch with ordinary people.

2. The differences between ordinary people and the ruling elite are much greater than the differences between ordinary people.

3. People like me have no influence on what the government does.

4. Politicians talk too much and take too little action.

\section{Demand for popular sovereignty}

1. The people should have the final say on the most important political issues by voting on them directly in referendums.

2. The people should be asked whenever important decisions are taken.

3. The people, not the politicians, should make our most important policy decisions.

4. The politicians in Parliament need to follow the will of the people.

\section{Belief in the homogeneity and virtuousness of the people}

1. Ordinary people all pull together.

2. Ordinary people are of good and honest character.

3. Although the Swiss are very different from each other, when it comes down to it they all think the same.

4. The Swiss are a coherent entity, rather than just a bunch of individuals. 
Elitist attitudes (Adopted from the existing literature: Akkerman et al. (2014); Hawkins \& Rovira Kaltwasser (2014))

1. Ordinary people can't be trusted to make the right decisions about our nation's problems.

2. Things are going well in our country because important decisions are left to the government.

3. All decisions that are important for a country should be left to politicians; that's what they are elected to do.

Pluralist attitudes ( 2 items were adopted from previous studies (Akkerman et al., 2014; Hawkins \& Rovira Kaltwasser, 2014) and 2 items were added by Schulz et al. (2018))

1. Democracy is about achieving compromise among differing viewpoints.

2. In a democracy, it's important to listen to groups whose opinion differs from your own.

3. In a democracy, it's important to take account of opposing views in decision making.

4. In a democracy, minority views should be taken into account. 


\section{PRÍLOHA 6}

\section{Dimensions of populism (Oliver \& Rahn, 2018)}

\section{Anti-elitism}

1. People like me don't have much say in what government does.

2. Politics usually boils down to a struggle between the people and the powerful.

3. The system is stacked against people like me.

4. It doesn't really matter who you vote for because the rich control both political parties.

5. People at the top usually get there because they have more talent and work harder/from some unfair advantage.

\section{Mistrust experts}

6. I'd rather put my trust in the wisdom of ordinary people than the opinions of experts and intellectuals.

7. When it comes to really important questions, scientific facts don't help very much.

8. Ordinary people can really use the help of experts to understand complicated things like science and health. *

9. Politics is ultimately a struggle between good and evil.

\section{National affiliation}

10. It would be unwise to trust the judgments of the American people for today's complicated political issues/I generally trust the collective judgments of the American people even for complex political issues.

11.I generally consider myself to be different than most Americans/like most other Americans.

12. How important is being an American to who you are?

\footnotetext{
* reverse scored
} 


\section{PRÍLOHA 7}

CSES module 5 (Hobolt et al., 2016)

Q4 Do you strongly agree, somewhat agree, neither agree nor disagree, somewhat disagree, strongly disagree with the following statements?

a. What people call compromise in politics is really just selling out one's principles.

b. Most politicians do not care about the people.

c. Most politicians are trustworthy

d. Politicians are the main problem in [COUNTRY]

e. Having a strong leader in government is good for [COUNTRY] even if the leader bends the rules to get things done.

f. The people, and not politicians, should make our most important policy decisions.

g. Most politicians care only about the interests of the rich and powerful

Q5 Now thinking about minorities. Do you strongly agree, somewhat agree, neither agree nor disagree, somewhat disagree, strongly disagree with the following statements?

a. It is better for society if minorities maintain their distinct customs and traditions.

b. The will of the majority should always prevail even over the rights of minorities.

Q5 And now thinking specifically about immigrants. Do you strongly agree, somewhat agree, neither agree nor disagree, or strongly disagree with the following statements?

c. Immigrants are generally good for [COUNTRY]'s economy.

d. [COUNTRY's] culture is generally harmed by immigrants.

e. Immigrants increase crime 
Q6 Now changing the topic... How important do you think the following is for being truly [NATIONALITY]... very important, fairly important, not very important, or not important at all?
a. To have been born in [COUNTRY].
b. To have [NATIONALITY] ancestry.
c. To be able to speak [COUNTRY NATIONAL LANGUAGES].
d. To follow [COUNTRY] customs and traditions

Q7 How widespread do you think corruption, such as bribe taking, is amongst politicians in [COUNTRY]: very widespread, quite widespread, not very widespread, it hardly happens at all? 


\section{PRÍLOHA 8}

\section{Populist Attitudes Scale (Castanho Silva et al., 2018)}

\section{People-centrism}

1. Politicians should always listen closely to the problems of the people.

2. Politicians don't have to spend time among ordinary people to do a good job. *

3. The will of the people should be the highest principle in this country's politics.

\section{Anti-elitism}

1. The government is pretty much run by a few big interests looking out for themselves.

2. Government officials use their power to try to improve people's lives. *

3. Quite a few of the people running the government are crooked.

\section{Manichaean outlook}

1. You can tell if a person is good or bad if you know their politics.

2. The people I disagree with politically are not evil. *

3. The people I disagree with politically are just misinformed.

*reverse scored 


\section{PRÍLOHA 9}

Modified the 8 items populist attitudes scale (items 1-6 are from Akkerman et al. (2014) by Van Hauwaert et al. (2019))

1. The politicians in Congress need to follow the will of the people. Popular sovereignty. *

2. The people, not the politicians, should make our most important policy decisions. Popular sovereignty.

3. The political differences between the people and the elite are larger than the differences among the people. Anti-elitism.

4. I would rather be represented by an ordinary citizen than an experienced politician. Popular sovereignty.

5. Politicians (elected officials) talk too much and take too little action. Anti-elitism.

6. What people call 'compromise' in politics is really just selling out on one's principles. Manichean worldview. *

7. The particular interests of the political class negatively affect the welfare of the people. Anti-elitism. *

8. Politicians always end up agreeing when it comes to protecting their privileges. Anti-elitism.

* modified the 3 items populist attitudes scale 

ISBN 978-80-89524-57-0

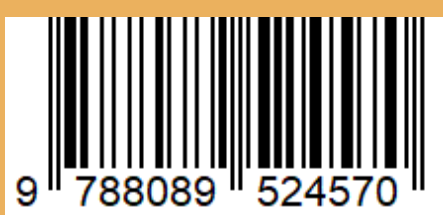

